\title{
Türkiye' de İl, Yıl ve Cinsiyet Kırılımlı Ortalama ve Beklenen Okullaşma Yılı ve İl Kırılımlı İnsani Gelişme Endeksi (2009-2019) ${ }^{1}$
}

\section{Mean and Expected Years Of Schooling by Province, Year and Gender and Human Development Index by Province in Turkey (2009-2019)}

\author{
Ferda Esin GÜLEL ${ }^{2}$ \\ Nurgül EVCIM ${ }^{3}$ \\ M. Ensar YEŞİLYURT 4a
}

\begin{abstract}
2 Pamukkale Üniversitesi, İ̈BF, Ekonometri Bölümü, fegulel@pau.edu.tr Orcid ID: 0000-0001-7060-7914
3 Pamukkale Üniversitesi, İ̈BF, İktisat Bölümü, nrgl_evcm@hotmail.com Orcid ID: 0000-0002-7584-7316

${ }^{4}$ Pamukkale Üniversitesi, İ̈BF, İktisat Bölümü, meyyurt@pau.edu.tr Orcid ID: 0000-0001-5610-3146

aYazışılan yazar/Corresponding author
\end{abstract}

$\begin{array}{ll}\text { Article Info: } & \text { Research Article } \\ \text { Date Submitted: } & 12.03 .2021 \\ \text { Date Revised: } & 16.08 .2021 \\ \text { Date Accepted: } & 09.08 .2021\end{array}$

\section{Abstract}

In this study, Human Development Index and sub-indices, which have been the subject of many researches in recent years, are calculated for the period of 2013-2018 and each provinces. Additionally, Mean Years of Schooling and Expected Years of Schooling are also calculated for the period of 2009-2019 and each proviences. Over the years, order differences have been observed in sub-indices and Human Development Index on the basis of provinces. The Human Development Index does not only show the level of income, but also consists of education, health and income indices. Therefore, there are differences between the income index and the Human Development Index rankings.

Keywords: Education Index, Health Index, Income Index, Human Development Index

JEL Codes: I15, I25, O15

$\begin{array}{ll}\text { Makale Bilgisi: } & \text { Araştırma Makalesi } \\ \text { Geliş Tarihi: } & 12.03 .2021 \\ \text { DüzeltmeTarihi: } & 06.08 .2021 \\ \text { Kabul Tarihi: } & 09.08 .2021\end{array}$

Özet

Bu çalışmada son yillarda pek çok araştırmaya konu olan Insani Gelişme Endeksi ve alt endeksler 2013-2018 periyodu için ve Ortalama Okullaşma Yılı ve Beklenen Okullaşma Yilı 2009-2019 periyodu için il kırılımında hesaplanmıştır. Yıllar itibariyle hem alt endeksler hem de Insani Gelişme Endeksi'nde iller bazında farklılıklar gözlenmiştir. İnsani Gelişme Endeksi'nin sadece gelirdeki seviyeyi göstermediğ $i$ eğitim, să̆lık ve gelir endekslerinden oluştuğu ve gelir endeksi ve İnsani Gelişme Endeksi sıralamaları arasında da farklılıklar bulunduğu görülmektedir.

Anahtar Kelimeler: Eğitim Endeksi, Sağlık Endeksi, Gelir Endeksi, İnsani Gelişme Endeksi

JEL Kodlarn: I15, I25, O15

\footnotetext{
1 Yazarlar bu çalışmanın tüm süreçlerinin araştırma ve yayın etiğine uygun olduğunu, etik kurallara ve bilimsel atıf gösterme ilkelerine uyduğunu beyan etmişlerdir. Aksi bir durumda Pamukkale Journal of Eurasian Socioeconomic Studies Dergisi sorumlu değildir. İntihal raporu alınmıştır. / The authors declared that all processes of this study comply with research and publication ethics, and comply with ethical rules and scientific citation principles. Otherwise, Pamukkale Journal of Eurasian Socioeconomic Studies is not responsible. A plagiarism report is received.
} 


\section{EXTENDED SUMMARY}

Purpose of the Study / Research Problem: The study aims to calculate the provincial and gender-based Mean and Expected Years of Schooling for the period of 2009-2019, and the Human Development Index for the period of 2013-2018. Research Questions: Is there a difference between the provinces in terms of the Human Development Index and Mean and Expected Years of Schooling between 2009-2019

Literature Review: Human Development Index for countries is reported annually by UNDP. Some researchers calculate this index on regional and provincial basis (Augusta PelinskiRaiher \& Ferrera-De-Lima, 2018; Majumder, R. 2005). Regional calculations were also made for Turkey (Özpınar and Koyuncu, 2016; Yeşilyurt et al., 2016a; Yeşilyurt et al., 2016b; Economic Policy Research Foundation of Turkey (TEPAV) https://www.tepav.org.tr/tr/yayin/ p/1564, 17.01.2021; Koca and İlgün, 2017; Çağlar and Keten, 2018; Sarı and Meydan, 2018; Temurlenk and Abar, 2019; Yiğiteli and Şanl1, 2020; Çağlar, 2020). Some studies discuss the importance of Mean and Expected Years of Schooling calculations (Yeşilyurt et al., 2016a; Yeşilyurt et al., 2016b; Gülel et al., 2017; Çağlar et al., 2017).

Method / Methodology: The Human Development Index consists of the subcomponents: Education Index, Health Index, and Income Index. We calculated the Education Index by taking the average of the Mean and Expected Years of Schooling values. We obtained the Health Index rescaling normalization (based in maxima and minima) using province's value by the lowest and highest Life Expectancy at Birth. To calculate the last sub-component Income Index, we used rescaling normalization (based in maxima and minima) using province's value by the lowest and highest natural logarithm of the value of gross domestic product per capita Finally, we acquired the Human Development Index by taking the geometric mean of these sub-components calculated for each province.

Result - Conclusion: When we compared the provinces according to the calculation results, both the Mean and Expected Years of Schooling and the Human Development Index became different. According to the calculations for the Mean Years of Schooling, the provinces with the lowest values in Turkey were Ağrı, Muş, Şanlıurfa, Şırnak and Van. In contrast, those with the highest values were Ankara, Eskişehir, İstanbul, İzmir and Kocaeli. According to the expected schooling year calculations, the values of the provinces show differences according to the years, and the lowest values are in Ağrı, Hakkâri, Muş, Şırnak and Van, while the highest values are in Amasya, Bilecik, Bolu, Isparta, Karabük and Rize. According to the values calculated for the Human Development Index, Ağrı, Kırıkkale, Siirt, Muş, and Van were the provinces with the lowest human development. At the same time, Muğla, Kocaeli, İzmir, İstanbul, Bolu, Antalya, and Ankara were the provinces with the highest human development.

\section{GİRIŞ}

Bir kalkınmanın göstergesi olarak kullanılan İnsani Gelişme Endeksi (İGE) ilk olarak 1990 yılında Birleşmiş Milletler Kalkınma Programı (UNDP) raporunda sunulmuştur. Endeks; eğitim, sağlık ve gelir olmak üzere üç bileşen üzerinden hesaplanmaktadır. UNDP her yıl ülkelere göre İGE'yi raporlamaktadır. Bu raporda ülkelerin alt yerleşim (bölge veya il gibi) birimlerine göre hesaplamalar yer almamaktadır. Ancak bazı araştırmacılar tarafından bölgesel endeksler de hesaplanmaktadır (Augusta Pelinski-Raiher \& Ferrera-De-Lima, 2018; 
Majumder, R. 2005). Türkiye'de de bölgesel endeks hesaplamaları yapılmıştır. Bu çalışmalar arasında Özpınar ve Koyuncu (2016), Yeşilyurt vd. (2016a), Yeşilyurt vd. (2016b), Türkiye Ekonomi Politikaları Araştırma Vakfı (TEPAV) (https://www.tepav.org.tr/tr/yayin/s/1564, 17.01.2021), Koca ve İlgün (2017), Çağlar ve Keten (2018), Sarı ve Meydan (2018), Temurlenk ve Abar (2019), Yiğiteli ve Şanlı (2020), Çağlar (2020) sayılabilir. Bu çalışmada ise ilk defa 20132018 yılları için İGE ve alt endeksler hesaplanarak il kırılımında sunulmuştur. Ortalama Okullaşma Yılı (OOY) ve Beklenen Okullaşma Yılı (BOY) verileri ise 2020 yılına kadar uzamaktadir.

\section{Veri Seti ve Tanımlar}

İGE; eğitim, sağlık ve gelir endeksi bileşenlerinden elde edilmektedir. Aşağıda bu endekslerin tanımları ve verilerin elde edildiği kaynaklar verilecektir:

Eğitim Endeksi, Ortalama Okullaşma Yılı (OOY) ve Beklenen Okullaşma Yılı (BOY) serileri kullanılarak hesaplanmaktadır. OOY; 25 yaş ve üzeri nüfusun eğitim hayatı boyunca ortalama olarak kaç yıl eğitim aldığını göstermektedir. BOY ise herhangi bir ildeki mevcut okullaşma oranı aynı kaldığı takdirde ilgili yılda okula başlayan bir çocuğun kaç yıl eğitim almasının beklendiğini göstermektedir (Barro \& Lee, 2013, 1993; Lee \& Barro, 2001). OOY hesaplamasında kullanılan veriler Türkiye İstatistik Kurumu (TÜİK) sitesinde Eğitim İstatistikleri-Ulusal Eğitim İstatistikleri başlığı altında yaş grupları, cinsiyet, yıl, il ve ilçe kırılıminda sunulmakta olup buradan OOY hesaplamaları yapılabilmektedir. BOY hesaplamalarında kullanılan veriler ise her yıl Milli Eğitim Bakanlığı (MEB) tarafından yayınlanan Resmi İstatistikler'den elde edilmekte, okullaşma ve eğitime devam eden öğrenciler okul ve yaş kırılımında sunulmaktadır (MEB, 2010, 2011,2012, 2013, 2014, 2015, $2016,2017,2018,2019,2020)$. Her iki okullaşma serilerinin önemi ve bunlara ilişkin tartışmalar literatürde bulunmaktadır (Yeşilyurt vd., 2016a; Yeşilyurt vd., 2016b; Gülel vd., 2017; Çağlar vd., 2017).

Sağlık endeksinin hesaplamasında ise Doğuşta Beklenen Yaşam Süresi (DBYS) verileri kullanılmaktadır. DBYS yeni doğmuş bir bireyin mevcut ölümlülük risklerine maruz kalması durumunda yaşaması beklenen ortalama yıl sayısı olarak tanımlanmaktadır ( https://tuikweb.tuik.gov.tr/PreHaberBultenleri.do?id=33711). DBYS, TÜIK tarafından hesaplanmakta olup 2013-2019 yılları için mevcuttur.

Gelir endeksi ise kişi başına Gayrisafi Yurtiçi Hasıla serileri kullanılarak hesaplanmaktadır. $\mathrm{Bu}$ veriler TÜIK tarafından yayınlanmaktadır (https://tuikweb.tuik.gov.tr/PreHaberBultenleri.do?id=33663) ve 2004-2019 yılları için mevcuttur.

\section{Kisitlar}

Türkiye'de okula başlama yılı, okul öncesinin yapısı ve yaygınlaşması, zorunlu eğitim süresi ve yaşı yıllar içinde değişmiştir. MEB'in yayınlarında okul öncesi eğitim verileri 3-5, 4-5 ve 5 yaş için verilmektedir. Bu konuda netlik oluşmadığından eğitim endeksi hesaplanırken okul öncesi eğitim için 1 yıl atanmıştır. Ayrıca doğal olarak göç ve benzeri etkilerin iller arasında yaratabileceği sapma ihmal edilmiştir (önemsenmeyecek düzeyde olduğu düşünülmektedir).

BOY hesaplamalarında üniversite eğitimi kapsam dışı bırakılmıştır. Çünkü üniversite öğrencilerinin ikamet ettikleri ve üniversite mezuniyet sonrası yaşadıkları iller üniversiteye 
devam ettikleri illerden farklı olabilmektedir. Bu tür hareketlilik ciddi bir sapmaya sebep olabileceğinden üniversite eğitimi bu çalışmada BOY hesaplamalarında kullanılmamıştır. Özpınar ve Koyuncu (2016)'da üniversite mezuniyeti bilgileri ile hesaplanan BOY verilerine ulaşılabilir. TÜIK tarafından yayınlanan OOY hesaplamalarında kullanılan veriler yaşanan yerdeki eğitim seviyelerini göstermektedir. Dolayısıyla üniversite eğitiminin kapsanması bir sorun yaratmadığından OOY hesaplamalarına üniversite eğitimi dahil edilmiştir.

\section{Yöntem}

Bu çalışma Yeşilyurt vd. (2016a), Yeşilyurt vd. (2016b), Gülel vd. (2017) ve Çağlar vd. (2017) çalışmalarının devamı ve söz konusu çalışmaları tamamlayıcı nitelikte olup aynı metodoloji kullanılmıştır. Ancak ilgili kurumların verilerini güncellemeleri ve hesaplamalarda yapılan bazı düzeltme ve güncellemeler nedeniyle önceki çalışmalara göre ciddi olmayan bazı farklılıklar gözlenebilir.

\section{Eğitim endeksi}

Eğitim endeksinin hesaplamasında yukarıda da belirtildiği gibi önce OOY ve BOY'un hesaplanması gerekmektedir. OOY ve BOY'ye ilişkin tanım ve formüller Barro ve Lee (1993, 2010 ve 2013), Lee ve Barro (2001) ve UNDP (2016) çalışmalarına dayalı olarak Yeşilyurt vd. (2016a), Yeşilyurt vd. (2016b), Gülel vd. (2017), Çağlar vd. (2016)'de kullanılmış, aynı formüllerden yararlanılarak hesaplamalar yapılmıştır. Buna göre hesaplamada kullanılan eşitlik

$$
\begin{aligned}
& \text { aşağıdaki } \\
& O O Y=\frac{\frac{P \alpha}{P} \sum_{\alpha} \sum_{l} H S_{\alpha l} . Y S_{\alpha l}}{9}
\end{aligned}
$$

gibidir:

Burada $\alpha=1, \ldots, 9,(1=25-29,2=30-34,3=35-39, \ldots, 9=65$ yaş ve üzeri $), l=$ $1, \ldots, 7 \quad(1=$ ilköğretim, $\quad 2$ =ilkokul, $\quad 3$ =Ortaokul ve Dengi Meslek Orta Okulu, $\quad 4=$ Lise ve Dengi Okullar, $5=$ Yüksekokul ve Fakülte, $6=$ Yüksek Lisans ve $7=$ Doktora), $H S_{\alpha l}$; $l$ eğitim düzeyine göre $\alpha$ yaş grubundaki mezunların nüfusa oranı, $Y S_{\alpha l}$ ise $l$ eğitim düzeyinin teorik eğitim yılını, $P_{\alpha}$; ilgili yaş grubundaki nüfusu, $P$; 25 yaş ve üstü nüfusu göstermektedir. Her bir yaş grubu her ilde farklı oranlarda olduğundan hesaplamada ağırlıklandırma yapılmıştır.

$$
B O Y=\sum_{l} n . O O_{l}
$$

Burada $l=1, \ldots, 4(1=$ okulöncesi, $2=$ ilkokul, $3=$ Ortaokul, $4=$ Lise $), 0 O_{l}$; ilgili eğitim düzeyindeki okullaşma oranı, $n$ ise ilgili eğitim düzeyinin kaç yıl sürdügünü (okulöncesi için 1, ilkokul için 4, ortaokul için 4, ortaöğretim (lise) için 4 olmak üzere) göstermektedir (Yukarıda bahsedilen nedenlerden dolayı liseden sonraki eğitim BOY hesaplamalarında kapsam dışında birakılmıştır).

Eğitim endeksi ise aşağıdaki formül ile hesaplanmaktadır:

$$
E I=\frac{O O Y E+E Y S E}{2}
$$


Ortalama Okullaşma Yılı Endeksi (OOYE) ve Beklenen Okullaşma Yılı Endeksinin (BOYE) ortalaması alınarak elde edilmektedir.

OOYE ve BOYE, en küçük-en büyük normalleştirilmesi yaklaşımıyla elde edilmektedir. Bu amaçla serideki en küçük ve en büyük OOY ve BOY değerleri belirlenerek (UNDP 2020 yılı İGE hesaplaması teknik notunda yer aldığı şekliyle) Denklem 4 ve 5 kullanılarak OOYE ve BOYE hesaplanmaktadir:

$$
\begin{aligned}
O O Y E & =\frac{O O Y-e n k O O Y}{\text { enbOOY-enkOOY }} \\
B O Y E & =\frac{B O Y-\text { enkBOY }}{\text { enbBOY-enkBOY }}
\end{aligned}
$$

OOYE, her bir ildeki OOY ile OOY en küçük olan ilin değeri arasındaki farkın, OOY'nin en büyük olduğu ilin değeri ile OOY en küçük olan ilin değeri arasındaki farka bölünmesiyle elde edilmektedir. BOYE ise her bir ildeki BOY ile BOY en küçük olan ilin değeri arasındaki farkın, BOY'nin en büyük olduğu ilin değeri ile BOY en küçük olan ilin değeri arasındaki farka bölünmesiyle elde edilmektedir.

Öte yandan özü itibariyle benzer olsa da UNESCO (2013)'te kullanilan OOYE ve BOYE formülleri farklıdır. Buna göre OOYE, OOY'nın 25 yaş ve üzeri nüfusun Ortalama Teorik Okul Yılına (TOY) ${ }^{1}$ bölünmesiyle, BOYE ise hâlihazırda eğitim sisteminde bulunan öğrencilerin Ortalama Teorik Beklenen Okullaşma Yılına $(T B O Y)^{2}$ bölünmesiyle elde edilmektedir (Denklem 6 ve 7 ):

$$
\begin{aligned}
& O O Y E=\frac{O O Y}{T O Y} \\
& B O Y E=\frac{B O Y}{T B O Y}
\end{aligned}
$$

Esas itibariyle Denklem 6 ve 7, Denklem 4 ve 5'ten türetilmiştir. UNESCO (2013)'te enkOOY ve enkBOY değerleri bazı ülkelerde modern anlamda eğitim sistemi olmaması nedeniyle/hiç eğitim almadan da yaşamak mümkün olduğundan sıfır olarak alınmıştır³. Bu değerler sıfır olarak alındığında Denklem 4 ve 5, Denklem 6 ve 7'ye dönüşmektedir.

Çalışmada OOYE ve BOYE yukarıda bahsedilen 2 farklı yol ile hesaplanmıştır. Bu bileşenler yardımı ile elde edilen İGE değerleri arasında çok yüksek (hepsi $0.90^{\prime}$ dan-çoğunlukla $0.97^{\prime}$ denbüyük) korelasyonlar elde edildiğinden çalışmada sadece Denklem 4 ve 5 'ten elde edilen değerlerle hesaplanan İGE sonuçları verilmiştir. Araştırmacılar diğer yöntemlerle hesaplanan sonuçları yazarlardan talep edebilirler.

\footnotetext{
${ }_{1}^{1}$ TOY; Teorik Okullaşma Yılını temsil etmektedir. 2013 yılında 25 yaş ve üzerinde olanlar için bu değer yaklaşık olarak 11 yıldır. Kısıtlar kısmında belirtildiği gibi BOY hesaplamalarında liseden sonraki eğitim kapsam dışında bırakılmıştır. Her ne kadar OOY hesaplamaları da liseden sonraki eğitimi de alarak hesaplama yapmak mümkün olsa da Eğitim Endeksi OOYE ve BOYE değerlerine dayalı olarak hesaplandığı için ikisi arasında uyum olması açısından OOYE'de liseye kadar olan eğitimi dikkate alarak hesaplanmıştır. Ancak okuyucuların ihtiyacı olabileceği düşünülerek tüm eğitim dikkate alan OOY değerleri Tablo 1-3'te sunulmuştur.

2 TBOY Teorik Ortalama Okullaşma Yılını temsil etmektedir. 2013 yılında bu değer yaklaşık olarak 13'tür.

${ }^{3}$ Her ne kadar daha yüksek OOY ve BOY'a sahip olan ülkeler olsa da UNESCO makul ve Dünya genelinde geçerli en büyük OOY ve BOY değerlerini sırasıyla 15 ve 18 yıl olarak kullanmıştır.
} 


\section{$\underline{\text { Sağllk Endeksi }}$}

Sağlık endeksi aşağıdaki formül yardımıyla elde edilmektedir.

$$
S E=\frac{D B Y S-S e r i d e k i \text { en } k \text { üçük değer }}{\text { Serideki en büyük değer-Serideki en küçük değer }} 4
$$

Her bir ildeki Doğuşta Beklenen Yaşam Süresi (DBYS) ile Doğuşta Beklenen Yaşam Süresi en küçük olan ilin değeri arasındaki farkın, Doğuşta Beklenen Yaşam Süresinin en büyük olduğu ilin değeri ile Doğuşta Beklenen Yaşam Süresi en küçük olan ilin değeri arasındaki farka bölünmesiyle elde edilmektedir. Bu formülde de en küçük-en büyük normalleştirilmesi yapılmaktadir.

\section{Gelir Endeksi}

Gelir endeksi aşağıdaki formülde elde edilmektedir.

$$
G E=\frac{\ln (K B G S Y \dot{I} H)-\ln (K B E N K G S Y \dot{I} H)}{\ln (K B E N B G S Y \dot{I} H)-\ln (K B E N K G S Y \dot{I} H)}
$$

Her bir ilin kişi başına düşen gayrisafi yurtiçi hasıla (KB GSYİH) değerinin doğal logaritması ve gelir serisinde en küçük hasılaya (KB ENKGSYİH) sahip olan ilin değerinin doğal logaritması arasındaki farkın; gelir serisinde en büyük hasılaya (KB ENBGSYIHH) sahip olan ilin değerinin doğal logaritması ve gelir serisinde en küçük hasılaya sahip olan ilin değerinin doğal logaritması arasındaki farka bölünmesiyle elde edilmektedir. Eğitim ve sağlık endekslerinde olduğu gibi gelir endeksi hesaplamasında da en küçük-en büyük normalleştirilmesi yapılmaktadır.

Hesaplanan İGE değeri 0,550'den küçükse düşük, 0,550-0,699 arasında ise orta, 0,700-0,799 arasında ise yüksek, 0,800 ve üzerinde ise çok yüksek insani gelişmişlik olarak adlandırılmaktadır.

\section{İnsani Gelișme Endeksi (İGE)}

İnsani Gelişme Endeksi, sağlık, eğitim ve gelir endekslerinin geometrik ortalaması alınarak elde edilmektedir:

$$
\dot{\mathrm{I}} G E=\sqrt[3]{S E * E E * G E}
$$

\section{Hesaplanan Seriler ve Sonuç}

Ek'te verilen Tablo 1-3; il ve yıl kırılımında kadınlar, erkekler ve genel kırılımlarında bütün eğitimi dikkate alan Ortalama Okullaşma Yılı, Tablo 4-6; il ve yıl kırılımında kadınlar, erkekler ve genel kırılımında liseye kadar olan eğitimi dikkate alan Ortalama Okullaşma Yılı, Tablo 79 ise il ve yıl kırılımında kadınlar, erkekler ve genel kırılımında Beklenen Okullaşma Yılı hesaplamalarını göstermektedir. Bütün tablolarda birinci sütunlar Türkiye geneli ve il

${ }^{4}$ 2013, 2014 ve 2017 yıllarında DBYS verisindeki en küçük değerler sırasıyla 74.9, 75, 76.1; en büyük değerler ise sırasıyla 80.7, 80.5 ve $80.7^{\prime}$ dir. 
kırılımında ölçüm birimlerini, ikinci ve onikinci sütunlar ise BOY için her bir eğitim öğretim yılındaki veya OOY için her bir yıldaki hesaplanmış değerleri göstermektedir. Her bir sütundaki en küçük beş değer ve en yüksek beş değer koyu olarak gösterilmiştir.

Tablo 10-12, 2013-2018 yılları il ve yıl kırılımlı eğitim, gelir ve sağlık endekslerini göstermektedir. Tablo 13, 2013-2018 yılları il kırılımlı IGGE skorlarını vermektedir. Tablo 13'te en yüksek ve en düşük İGE skoruna sahip 5 il koyu ile belirtilmiştir.

$\mathrm{Bu}$ hesaplamalara ilişkin ham veriler büyük boyutta olduğu için burada verilmemiştir. Talep halinde düzenlenmiş olan veri setleri araştırmacılarla paylaşılabilir.

\section{Araştırmacıların Katkı Oranı Beyanı / Researchers' Contribution Rate Statement}

Yazarlar bu çalışmaya eşit şekilde katkı sağladıklarını beyan etmiştir.

The authors declare that they have contributed equally to this article.

\section{Araştırmacıların Çatışma Beyanı / Researchers'Conflict of Interest Statement Yazarlar, bu çalışmada potansiyel bir çıkar çatışması olmadığını beyan etmişlerdir. The authors declare that there is no potential conflict of interest in this study.}

\section{KAYNAKÇA}

Augusta Pelinski-Raiher, A. \& Ferrera-De-Lima, J. (2018). Human development and underdevelopment in Brazil. Economía, Sociedad y Territorio 56, 77-105.

Barro, R. J. \& Lee, J. W. (1993). International Comparisons of Educational Attainment. Journal of Monetary Economics, 32, 363-94.

Barro, R. J. \& Lee, J. W. (2001). International data on educational attainment: updates and implications. Oxford Economic Papers, 53(3), 541-563.

Barro, R. J. \& Lee, J. W. (2010). A New Data Set of Educational Attainment in the World, 19502010. NBER Working Paper No. 15902.

Barro, R. J. \& Lee, J. W. (2013). A New Data Set of Educational Attainment in the World, 19502010. Journal of Development Economics, 104, 184-198.

Çağlar, A., Gülel, F. E., Yesilyurt, M. E., Yesilyurt, F. \& Karadeniz, O. (2017). Türkiye' de İl, Yıl ve Cinsiyet Kırılımlı Ortalama ve Beklenen Okullaşma Yılı. Yönetim Bilimleri Dergisi, 15(30), 619-641.

Çağlar, A. \& Keten, N. D. (2018). İllerin İnsani Gelişme Endeksinin Veri Zarflama Analizi İle Ölçülmesi. Ege Akademik Bakış Dergisi, 18(4), 565-578.

Çağlar, A. (2020). İllerin Yaşam Kalitesi: Türkiye İstatistik Kurumu Verileriyle Veri Zarflama Analizi'ne Dayalı Bir Endeks. Eskişehir Osmangazi Üniversitesi İktisadi ve İdari Bilimler Dergisi, 15(3), 875-902.

Gülel, F. E., Çağlar, A., Kangallı-Uyar, S. G., Karadeniz, O. \& Yeşilyurt, M. E. (2017). Türkiye'de İllere Göre İnsani Gelişme Endeksi. Pamukkale Üniversitesi Sosyal Bilimler Enstitüsü Dergisi, 27, 208-216.

Human Development Report (2016). UNDP, http://hdr.undp.org 
Koca, G. Ş. \& İlgün, G. (2017). Seçilmiş Olan Sağlık Göstergeleri Açısından Orta Gelirli Ülkelerin Sınıflandırılması. International Journal of Academic Value Studies, 3(13), 328-336.

Majumder, R. (2005). Human Development in India: Regional Pattern and Policy Issues. Indian Journal of Applied Economics, 2 (1), 1-26

Milli Eğitim Bakanlığı (MEB), Resmi istatistikler- Milli Eğitim İstatistikleri, Örgün Eğitim (2009-2010). https://sgb.meb.gov.tr/www/resmi-istatistikler/icerik/64

Milli Eğitim Bakanlığı (MEB), Resmi istatistikler- Milli Eğitim İstatistikleri, Örgün Eğitim (2010-2011). https://sgb.meb.gov.tr/www/resmi-istatistikler/icerik/64

Milli Eğitim Bakanlığı (MEB), Resmi istatistikler- Milli Eğitim İstatistikleri, Örgün Eğitim (2011-2012). https://sgb.meb.gov.tr/www/resmi-istatistikler/icerik/64

Milli Eğitim Bakanlığı (MEB), Resmi istatistikler- Milli Eğitim İstatistikleri, Örgün Eğitim (2012-2013). https://sgb.meb.gov.tr/www/resmi-istatistikler/icerik/64

Milli Eğitim Bakanlığı (MEB), Resmi istatistikler- Milli Eğitim İstatistikleri, Örgün Eğitim (2013-2014). https://sgb.meb.gov.tr/www/resmi-istatistikler/icerik/64

Milli Eğitim Bakanlığı (MEB), Resmi istatistikler- Milli Eğitim İstatistikleri, Örgün Eğitim (2014-2015). https://sgb.meb.gov.tr/www/resmi-istatistikler/icerik/64

Milli Eğitim Bakanlığı (MEB), Resmi istatistikler- Milli Eğitim İstatistikleri, Örgün Eğitim (2015-2016). https://sgb.meb.gov.tr/www/resmi-istatistikler/icerik/64

Milli Eğitim Bakanlığı (MEB), Resmi istatistikler- Milli Eğitim İstatistikleri, Örgün Eğitim (2016-2017). https://sgb.meb.gov.tr/www/resmi-istatistikler/icerik/64

Milli Eğitim Bakanlığı (MEB), Resmi istatistikler- Milli Eğitim İstatistikleri, Örgün Eğitim (2017-2018). https://sgb.meb.gov.tr/www/resmi-istatistikler/icerik/64

Milli Eğitim Bakanlığı (MEB), Resmi istatistikler- Milli Eğitim İstatistikleri, Örgün Eğitim (2018-2019). https://sgb.meb.gov.tr/www/resmi-istatistikler/icerik/64

Milli Eğitim Bakanlığı (MEB), Resmi istatistikler- Milli Eğitim İstatistikleri, Örgün Eğitim (2019-2020). https://sgb.meb.gov.tr/www/resmi-istatistikler/icerik/64

Özpınar, E. \& Koyuncu E. (2016). Türkiye'de insani gelişmişlik iller arasında nasıl farklılaşıyor? 81 il için insani gelişmişlik endeksi (Değerlendirme Notu N201625). Ankara: Türkiye Ekonomi Politikaları Araştırma Vakfı Yayınları.

Sarı, V. İ. \& Meydan, M. C. (2018). İnsani Gelişme Endeksi ve Alt Endekslerinin Türkiye'deki İller İçin Ölçülmesi ve Analizi. İdealkent, 9(24), 387-429.

Temurlenk, M. S. \& Abar, H. (2019). Türkiye'deki İllerin Sosyoekonomik Gelişmişlik Seviyeleri: 2008-2016 Dönemi. Atatürk Üniversitesi İktisadi ve İdari Bilimler Dergisi, 33(4), 1115-1135.

TÜİK, (2009-2018) Eğitim İstatistikleri ve Adrese Dayalı Nüfus Kayıt Sistemi.

Türkiye Ekonomi Politikaları Araştırma Vakfı

(https://www.tepav.org.tr/tr/yayin/s/1564, Erişim Tarihi: 17.01.2021

(TEPAV) 
UNESCO (2013). UIS Methodology for Estimation of Mean Years of Schooling.

UNDP (2020). http://hdr.undp.org/en/content/hdr-technical-notes

Yeşilyurt, F., Yeşilyurt, M. E., Karadeniz, O., Gülel, F. E., Karadeniz-Kabakçı, H. \& Çağlar, A. (2016a). Cinsiyet ve İl Kırılımlı İnsani Gelişme Endeksi: Türkiye Örneği. Ekonomi-TEK, $5(3), 21-56$.

Yeşilyurt, M., Karadeniz, O., Gülel, F. E., Çağlar, A. \& Uyar, S. (2016b). Türkiye'de İllere Göre Ortalama ve Beklenen Okullaşma Yilı. Pamukkale Journal of Eurasian Socioeconomic Studies, 3 (1) , 1-7. DOI: 10.5505/pjess.2016.55706

Yiğiteli, N. \& Şanlı, D. (2020). Türkiye'de İllere Göre İnsani Gelişme Endekslerinin Hesaplanması: 2009-2018 Kapsamlı Bir Panel Veri Seti. Journal of Economy Culture and Society, 61(1).

\section{EKLER}

Tablo 1. İl ve Yıl Kırılımında Kadınlar İçin Bütün Eğitimi Dikkate Alan Ortalama Okullaşma Yılı (Mean Years of Schooling-Women)

\begin{tabular}{|c|c|c|c|c|c|c|c|c|c|c|c|}
\hline & 2009 & 2010 & 2011 & 2012 & 2013 & 2014 & 2015 & 2016 & 2017 & 2018 & 2019 \\
\hline Türkiye & 4.43 & 4.92 & 5.27 & 5.42 & 5.55 & 5.79 & 5.98 & 6.20 & 6.37 & 6.59 & 6.89 \\
\hline Adana & 5.38 & 5.87 & 6.16 & 6.18 & 6.40 & 6.63 & 6.82 & 7.01 & 7.17 & 7.36 & 7.53 \\
\hline Adıyaman & 3.59 & 4.17 & 4.51 & 4.85 & 5.02 & 5.25 & 5.46 & 5.74 & 5.93 & 6.22 & 6.67 \\
\hline Afyonkarahisar & 4.57 & 4.95 & 5.37 & 5.47 & 5.59 & 5.77 & 5.95 & 6.13 & 6.29 & 6.46 & 6.62 \\
\hline Ăgr1 & 1.92 & 2.56 & 3.01 & 3.10 & 3.15 & 3.37 & 3.54 & 3.73 & 3.93 & 4.16 & 4.70 \\
\hline Aksaray & 4.19 & 4.64 & 5.09 & 5.22 & 5.35 & 5.56 & 5.73 & 5.93 & 6.08 & 6.26 & 6.46 \\
\hline Amasya & 4.79 & 5.22 & 5.50 & 5.66 & 5.79 & 6.02 & 6.20 & 6.45 & 6.61 & 6.76 & 6.95 \\
\hline Ankara & 7.06 & 7.42 & 7.65 & 7.77 & 7.93 & 8.20 & 8.41 & 8.56 & 8.70 & 8.83 & 8.92 \\
\hline Antalya & 5.82 & 6.28 & 6.55 & 6.66 & 6.75 & 7.05 & 7.26 & 7.43 & 7.61 & 7.74 & 7.80 \\
\hline Ardahan & 3.56 & 4.10 & 4.52 & 4.64 & 4.74 & 4.94 & 5.15 & 5.40 & 5.56 & 5.81 & 6.09 \\
\hline Artvin & 4.74 & 5.17 & 5.49 & 5.67 & 5.86 & 6.11 & 6.35 & 6.58 & 6.74 & 7.00 & 7.19 \\
\hline Aydın & 5.11 & 5.55 & 5.97 & 6.09 & 6.20 & 6.48 & 6.66 & 6.90 & 7.07 & 7.28 & 7.45 \\
\hline Balıkesir & 5.28 & 5.62 & 5.99 & 6.11 & 6.24 & 6.52 & 6.68 & 6.88 & 7.03 & 7.25 & 7.39 \\
\hline Bartın & 4.13 & 4.56 & 4.88 & 5.01 & 5.16 & 5.38 & 5.59 & 5.83 & 5.99 & 6.20 & 6.38 \\
\hline Batman & 2.52 & 3.44 & 3.86 & 4.00 & 4.13 & 4.37 & 4.61 & 4.87 & 5.14 & 5.46 & 6.38 \\
\hline Bayburt & 3.70 & 4.67 & 4.73 & 4.91 & 5.10 & 5.27 & 5.53 & 5.76 & 5.91 & 6.06 & 6.48 \\
\hline Bilecik & 5.47 & 5.88 & 6.24 & 6.36 & 6.49 & 6.70 & 6.86 & 7.06 & 7.23 & 7.40 & 7.58 \\
\hline Bingöl & 2.75 & 3.41 & 3.92 & 4.06 & 4.23 & 4.51 & 4.79 & 5.10 & 5.38 & 5.74 & 6.94 \\
\hline Bitlis & 2.61 & 3.24 & 3.64 & 3.77 & 3.87 & 4.09 & 4.28 & 4.57 & 4.79 & 5.10 & 6.02 \\
\hline Bolu & 5.15 & 5.57 & 5.87 & 6.01 & 6.15 & 6.36 & 6.56 & 6.78 & 6.96 & 7.11 & 7.25 \\
\hline Burdur & 4.96 & 5.33 & 5.60 & 5.73 & 5.87 & 6.06 & 6.25 & 6.47 & 6.64 & 6.88 & 7.05 \\
\hline Bursa & 5.70 & 6.13 & 6.44 & 6.57 & 6.70 & 7.00 & 7.18 & 7.36 & 7.55 & 7.69 & 7.83 \\
\hline Çanakkale & 5.39 & 5.73 & 6.09 & 6.24 & 6.39 & 6.64 & 6.83 & 7.07 & 7.25 & 7.46 & 7.65 \\
\hline Çankırı & 4.44 & 4.84 & 5.22 & 5.35 & 5.46 & 5.61 & 5.78 & 5.98 & 6.14 & 6.39 & 6.49 \\
\hline Çorum & 4.04 & 4.50 & 4.82 & 4.97 & 5.10 & 5.31 & 5.50 & 5.73 & 5.89 & 6.08 & 6.26 \\
\hline Denizli & 5.22 & 5.67 & 6.10 & 6.24 & 6.39 & 6.62 & 6.82 & 7.04 & 7.21 & 7.42 & 7.57 \\
\hline Diyarbakır & 2.75 & 3.36 & 3.69 & 3.87 & 4.02 & 4.26 & 4.47 & 4.71 & 4.94 & 5.25 & 5.93 \\
\hline Düzce & 4.72 & 5.22 & 5.45 & 5.71 & 5.87 & 6.13 & 6.37 & 6.60 & 6.80 & 7.00 & 7.19 \\
\hline Edirne & 5.57 & 5.94 & 6.20 & 6.32 & 6.45 & 6.66 & 6.82 & 7.03 & 7.19 & 7.38 & 7.54 \\
\hline
\end{tabular}




\begin{tabular}{|c|c|c|c|c|c|c|c|c|c|c|c|}
\hline Elazığ & 4.07 & 4.58 & 4.90 & 5.04 & 5.20 & 5.46 & 5.68 & 5.89 & 6.08 & 6.33 & 6.76 \\
\hline Erzincan & 4.43 & 4.91 & 5.21 & 5.38 & 5.56 & 5.77 & 6.03 & 6.26 & 6.46 & 6.65 & 6.96 \\
\hline Erzurum & 3.89 & 4.42 & 4.77 & 4.92 & 5.04 & 5.26 & 5.49 & 5.70 & 5.92 & 6.13 & 6.33 \\
\hline Eskişehir & 6.18 & 6.59 & 6.87 & 7.02 & 7.19 & 7.47 & 7.66 & 7.83 & 7.97 & 8.12 & 8.24 \\
\hline Gaziantep & 4.04 & 4.65 & 5.00 & 5.32 & 5.43 & 5.67 & 5.87 & 6.09 & 6.30 & 6.50 & 6.70 \\
\hline Giresun & 4.02 & 4.48 & 4.73 & 4.86 & 5.00 & 5.25 & 5.48 & 5.74 & 5.90 & 6.09 & 6.33 \\
\hline Gümüşhane & 4.04 & 4.41 & 4.84 & 4.99 & 5.18 & 5.36 & 5.65 & 5.76 & 5.74 & 6.35 & 6.35 \\
\hline Hakkâri & 2.42 & 3.06 & 3.66 & 3.86 & 3.89 & 4.14 & 4.33 & 4.50 & 4.78 & 5.30 & 7.19 \\
\hline Hatay & 4.61 & 5.09 & 5.43 & 5.55 & 5.67 & 5.91 & 6.12 & 6.35 & 6.51 & 6.70 & 6.90 \\
\hline Iğdır & 3.11 & 3.81 & 4.32 & 4.46 & 4.57 & 4.81 & 5.02 & 5.27 & 5.44 & 5.72 & 6.12 \\
\hline Isparta & 5.42 & 5.84 & 6.09 & 6.23 & 6.37 & 6.61 & 6.83 & 7.08 & 7.24 & 7.43 & 7.58 \\
\hline İstanbul & 6.29 & 6.74 & 7.00 & 7.12 & 7.27 & 7.62 & 7.85 & 7.99 & 8.09 & 8.24 & 8.30 \\
\hline İzmir & 6.29 & 6.66 & 7.06 & 7.17 & 7.30 & 7.54 & 7.75 & 7.92 & 8.08 & 8.27 & 8.42 \\
\hline Kahramanmaraş & 4.05 & 4.61 & 4.92 & 5.05 & 5.20 & 5.46 & 5.68 & 5.94 & 6.12 & 6.35 & 6.57 \\
\hline Karabük & 4.79 & 5.27 & 5.55 & 5.71 & 5.86 & 6.07 & 6.27 & 6.51 & 6.68 & 6.87 & 7.09 \\
\hline Karaman & 4.93 & 5.38 & 5.69 & 5.86 & 6.00 & 6.21 & 6.40 & 6.63 & 6.77 & 6.98 & 7.14 \\
\hline Kars & 3.46 & 4.10 & 4.55 & 4.65 & 4.77 & 5.00 & 5.20 & 5.43 & 5.63 & 5.84 & 6.11 \\
\hline Kastamonu & 3.99 & 4.37 & 4.64 & 4.78 & 4.92 & 5.12 & 5.31 & 5.52 & 5.69 & 5.87 & 6.07 \\
\hline Kayseri & 5.08 & 5.57 & 5.86 & 6.15 & 6.30 & 6.53 & 6.75 & 6.94 & 7.12 & 7.29 & 7.46 \\
\hline Kırıkkale & 4.82 & 5.37 & 5.90 & 6.02 & 6.13 & 6.33 & 6.49 & 6.67 & 6.83 & 7.00 & 7.17 \\
\hline Kirklareli & 5.84 & 6.27 & 6.55 & 6.67 & 6.79 & 7.00 & 7.15 & 7.35 & 7.50 & 7.67 & 7.83 \\
\hline Kırşehir & 4.79 & 5.22 & 5.67 & 5.78 & 5.91 & 6.12 & 6.29 & 6.48 & 6.56 & 6.70 & 6.86 \\
\hline Kilis & 3.87 & 4.73 & 5.18 & 5.34 & 5.45 & 5.70 & 5.82 & 6.09 & 6.29 & 6.66 & 7.28 \\
\hline Kocaeli & 5.66 & 6.21 & 6.56 & 6.71 & 6.86 & 7.19 & 7.41 & 7.62 & 7.79 & 8.02 & 8.17 \\
\hline Konya & 4.88 & 5.26 & 5.52 & 5.68 & 5.81 & 6.05 & 6.25 & 6.45 & 6.63 & 6.82 & 6.99 \\
\hline Kütahya & 4.65 & 5.01 & 5.36 & 5.49 & 5.63 & 5.81 & 6.00 & 6.22 & 6.39 & 6.59 & 6.80 \\
\hline Malatya & 4.60 & 5.11 & 5.52 & 5.66 & 5.84 & 6.10 & 6.33 & 6.54 & 6.72 & 6.93 & 7.13 \\
\hline Manisa & 4.84 & 5.25 & 5.61 & 5.74 & 5.87 & 6.07 & 6.25 & 6.46 & 6.62 & 6.83 & 7.02 \\
\hline Mardin & 2.58 & 3.11 & 3.53 & 3.65 & 3.76 & 3.98 & 4.20 & 4.40 & 4.63 & 4.87 & 5.41 \\
\hline Mersin & 5.38 & 5.79 & 6.15 & 6.26 & 6.36 & 6.60 & 6.79 & 6.96 & 7.11 & 7.29 & 7.43 \\
\hline Muğla & 5.78 & 6.18 & 6.53 & 6.63 & 6.70 & 7.11 & 7.28 & 7.50 & 7.70 & 7.93 & 8.06 \\
\hline Muş & 1.94 & 2.65 & 3.10 & 3.24 & 3.31 & 3.50 & 3.69 & 3.94 & 4.18 & 4.41 & 5.61 \\
\hline Nevşehir & 4.78 & 5.25 & 5.66 & 5.79 & 5.94 & 6.13 & 6.32 & 6.51 & 6.67 & 6.82 & 6.99 \\
\hline Niğde & 4.56 & 5.06 & 5.51 & 5.61 & 5.76 & 5.95 & 6.13 & 6.35 & 6.52 & 6.70 & 6.89 \\
\hline Ordu & 4.03 & 4.52 & 4.74 & 4.88 & 5.00 & 5.24 & 5.44 & 5.65 & 5.82 & 6.04 & 6.24 \\
\hline Osmaniye & 4.77 & 5.30 & 5.60 & 5.73 & 5.89 & 6.16 & 6.40 & 6.68 & 6.86 & 7.09 & 7.29 \\
\hline Rize & 4.52 & 5.05 & 5.39 & 5.54 & 5.70 & 5.94 & 6.21 & 6.52 & 6.73 & 6.97 & 7.23 \\
\hline Sakarya & 5.07 & 5.54 & 5.89 & 6.03 & 6.18 & 6.45 & 6.65 & 6.85 & 7.07 & 7.28 & 7.46 \\
\hline Samsun & 4.72 & 5.16 & 5.47 & 5.63 & 5.79 & 6.04 & 6.27 & 6.50 & 6.67 & 6.87 & 7.05 \\
\hline Siirt & 2.25 & 2.95 & 3.36 & 3.46 & 3.57 & 3.93 & 3.96 & 4.19 & 4.42 & 4.70 & 5.44 \\
\hline Sinop & 4.37 & 4.79 & 5.10 & 5.21 & 5.32 & 5.53 & 5.73 & 5.96 & 6.12 & 6.28 & 6.44 \\
\hline Sivas & 4.32 & 4.79 & 5.06 & 5.33 & 5.47 & 5.62 & 5.84 & 6.07 & 6.27 & 6.41 & 6.67 \\
\hline Şanlıurfa & 2.06 & 2.65 & 2.97 & 3.07 & 3.14 & 3.39 & 3.57 & 3.76 & 3.97 & 4.19 & 4.84 \\
\hline Şirnak & 1.70 & 2.38 & 2.86 & 2.96 & 3.04 & 3.25 & 3.36 & 3.50 & 3.86 & 4.21 & 5.58 \\
\hline Tekirdağ & 5.87 & 6.34 & 6.64 & 6.75 & 6.87 & 7.13 & 7.30 & 7.48 & 7.61 & 7.79 & 7.95 \\
\hline Tokat & 4.23 & 4.69 & 4.96 & 5.12 & 5.24 & 5.44 & 5.64 & 5.86 & 6.02 & 6.22 & 6.41 \\
\hline Trabzon & 4.87 & 5.32 & 5.61 & 5.77 & 5.93 & 6.16 & 6.45 & 6.71 & 6.91 & 7.10 & 7.29 \\
\hline
\end{tabular}




\begin{tabular}{|l|c|c|c|c|c|c|c|c|c|c|c|}
\hline Tunceli & 4.49 & 4.99 & 5.47 & 5.63 & 5.85 & 6.16 & 6.35 & 6.58 & 6.79 & 7.00 & 7.27 \\
\hline Uşak & 4.92 & 5.36 & 5.74 & 5.86 & 6.00 & 6.18 & 6.36 & 6.55 & 6.69 & 6.87 & 7.05 \\
\hline Van & 2.48 & 3.07 & 3.31 & 3.47 & 3.60 & 3.84 & 4.05 & 4.25 & 4.50 & 4.75 & 5.21 \\
\hline Yalova & 5.81 & 6.26 & 6.54 & 6.68 & 6.79 & 7.16 & 7.28 & 7.35 & 7.45 & 7.50 & 7.52 \\
\hline Yozgat & 4.09 & 4.48 & 4.77 & 5.06 & 5.16 & 5.33 & 5.48 & 5.68 & 5.82 & 5.97 & 6.18 \\
\hline Zonguldak & 4.81 & 5.17 & 5.42 & 5.55 & 5.68 & 5.88 & 6.06 & 6.24 & 6.38 & 6.56 & 6.70 \\
\hline
\end{tabular}

Tablo 2. İl ve Yil Kırılımında Erkekler İçin Bütün Eğitimi Dikkate Alan Ortalama Okullaşma Okullaşma Y1lı (Mean Years of Schooling-Men)

\begin{tabular}{|c|c|c|c|c|c|c|c|c|c|c|c|}
\hline & 2009 & 2010 & 2011 & 2012 & 2013 & 2014 & 2015 & 2016 & 2017 & 2018 & 2019 \\
\hline Türkiye & 6.51 & 7.13 & 7.53 & 7.67 & 7.80 & 8.06 & 8.26 & 8.43 & 8.57 & 8.74 & 8.90 \\
\hline Adana & 6.95 & 7.60 & 7.94 & 7.93 & 8.15 & 8.37 & 8.58 & 8.74 & 8.86 & 9.02 & 9.17 \\
\hline Adiyaman & 6.30 & 6.80 & 7.19 & 7.56 & 7.72 & 7.95 & 8.17 & 8.39 & 8.53 & 8.70 & 8.95 \\
\hline Afyonkarahisar & 6.69 & 7.26 & 7.63 & 7.72 & 7.83 & 8.00 & 8.17 & 8.31 & 8.43 & 8.55 & 8.65 \\
\hline Ağrı & 4.26 & 5.11 & 5.88 & 5.98 & 6.07 & 6.43 & 6.66 & 6.92 & 7.06 & 7.35 & 7.76 \\
\hline Aksaray & 6.13 & 6.72 & 7.21 & 7.32 & 7.41 & 7.62 & 7.78 & 7.92 & 8.02 & 8.14 & 8.25 \\
\hline Amasya & 6.74 & 7.29 & 7.57 & 7.73 & 7.89 & 8.15 & 8.32 & 8.51 & 8.64 & 8.88 & 9.03 \\
\hline Ankara & 8.64 & 9.04 & 9.28 & 9.39 & 9.53 & 9.84 & 10.03 & 10.12 & 10.21 & 10.31 & 10.35 \\
\hline Antalya & 7.08 & 7.60 & 7.89 & 8.03 & 8.11 & 8.48 & 8.71 & 8.86 & 9.00 & 9.09 & 9.12 \\
\hline Ardahan & 5.77 & 6.32 & 6.91 & 7.02 & 7.11 & 7.39 & 7.61 & 7.90 & 8.04 & 8.28 & 8.48 \\
\hline Artvin & 7.09 & 7.72 & 8.09 & 8.27 & 8.43 & 8.72 & 8.94 & 9.10 & 9.24 & 9.42 & 9.54 \\
\hline Aydin & 6.45 & 7.01 & 7.44 & 7.56 & 7.65 & 7.95 & 8.12 & 8.33 & 8.48 & 8.65 & 8.77 \\
\hline Balıkesir & 6.74 & 7.21 & 7.61 & 7.73 & 7.85 & 8.13 & 8.31 & 8.47 & 8.61 & 8.78 & 8.88 \\
\hline Bartın & 6.04 & 6.82 & 7.10 & 7.22 & 7.36 & 7.60 & 7.79 & 7.92 & 8.06 & 8.24 & 8.38 \\
\hline Batman & 5.84 & 7.03 & 7.51 & 7.67 & 7.82 & 8.05 & 8.30 & 8.52 & 8.69 & 8.92 & 9.31 \\
\hline Bayburt & 6.54 & 7.18 & 7.66 & 7.82 & 7.99 & 8.14 & 8.28 & 8.49 & 8.74 & 8.79 & 9.16 \\
\hline Bilecik & 7.29 & 7.89 & 8.22 & 8.32 & 8.40 & 8.60 & 8.75 & 8.87 & 9.00 & 9.15 & 9.25 \\
\hline Bingöl & 5.64 & 6.42 & 7.03 & 7.19 & 7.37 & 7.69 & 7.97 & 8.22 & 8.42 & 8.64 & 9.17 \\
\hline Bitlis & 5.65 & 6.51 & 7.10 & 7.27 & 7.39 & 7.68 & 7.91 & 8.20 & 8.33 & 8.67 & 8.96 \\
\hline Bolu & 7.06 & 7.58 & 7.88 & 8.00 & 8.14 & 8.38 & 8.53 & 8.71 & 8.85 & 8.95 & 8.99 \\
\hline Burdur & 6.78 & 7.29 & 7.52 & 7.64 & 7.77 & 7.98 & 8.17 & 8.33 & 8.52 & 8.72 & 8.84 \\
\hline Bursa & 7.25 & 7.82 & 8.13 & 8.24 & 8.35 & 8.66 & 8.83 & 8.96 & 9.10 & 9.19 & 9.27 \\
\hline Çanakkale & 6.73 & 7.19 & 7.59 & 7.72 & 7.89 & 8.15 & 8.33 & 8.44 & 8.64 & 8.81 & 8.93 \\
\hline Çankırı & 6.69 & 7.19 & 7.56 & 7.70 & 7.79 & 7.97 & 8.15 & 8.23 & 8.41 & 8.53 & 8.60 \\
\hline Çorum & 5.92 & 6.51 & 6.89 & 7.04 & 7.17 & 7.41 & 7.59 & 7.76 & 7.89 & 8.03 & 8.19 \\
\hline Denizli & 6.69 & 7.27 & 7.70 & 7.82 & 7.95 & 8.19 & 8.37 & 8.53 & 8.68 & 8.83 & 8.93 \\
\hline Diyarbakır & 5.49 & 6.34 & 6.80 & 6.99 & 7.14 & 7.45 & 7.69 & 7.95 & 8.13 & 8.42 & 8.85 \\
\hline Düzce & 6.60 & 7.34 & 7.68 & 7.80 & 7.95 & 8.20 & 8.39 & 8.55 & 8.73 & 8.86 & 8.99 \\
\hline Edirne & 6.83 & 7.23 & 7.55 & 7.66 & 7.81 & 8.07 & 8.20 & 8.36 & 8.51 & 8.66 & 8.76 \\
\hline Elazı ̆ & 6.96 & 7.45 & 7.95 & 8.08 & 8.24 & 8.54 & 8.78 & 8.96 & 9.10 & 9.24 & 9.46 \\
\hline Erzincan & 6.95 & 7.50 & 7.80 & 7.96 & 8.17 & 8.37 & 8.66 & 8.73 & 8.91 & 9.00 & 9.30 \\
\hline Erzurum & 6.62 & 7.21 & 7.58 & 7.76 & 7.89 & 8.17 & 8.42 & 8.62 & 8.79 & 8.94 & 9.12 \\
\hline Eskişehir & 7.92 & 8.43 & 8.70 & 8.83 & 8.97 & 9.26 & 9.41 & 9.54 & 9.64 & 9.74 & 9.80 \\
\hline Gaziantep & 6.08 & 6.90 & 7.26 & 7.60 & 7.69 & 7.91 & 8.06 & 8.24 & 8.37 & 8.54 & 8.70 \\
\hline Giresun & 6.32 & 6.85 & 7.15 & 7.28 & 7.41 & 7.69 & 7.93 & 8.11 & 8.23 & 8.37 & 8.52 \\
\hline Gümüşhane & 6.58 & 6.94 & 7.50 & 7.64 & 7.80 & 8.02 & 8.24 & 8.06 & 7.96 & 8.69 & 8.41 \\
\hline Hakkâri & 5.74 & 6.45 & 7.40 & 7.55 & 7.76 & 8.06 & 8.35 & 8.39 & 8.56 & 9.12 & 9.43 \\
\hline
\end{tabular}




\begin{tabular}{|c|c|c|c|c|c|c|c|c|c|c|c|}
\hline Hatay & 6.28 & 6.82 & 7.20 & 7.30 & 7.44 & 7.71 & 7.93 & 8.16 & 8.26 & 8.39 & 8.53 \\
\hline Ĭğdır & 5.14 & 5.98 & 6.63 & 6.75 & 6.89 & 7.14 & 7.37 & 7.56 & 7.74 & 8.02 & 8.20 \\
\hline Isparta & 7.38 & 7.92 & 8.10 & 8.23 & 8.37 & 8.65 & 8.87 & 9.02 & 9.17 & 9.28 & 9.37 \\
\hline İstanbul & 7.38 & 7.91 & 8.19 & 8.30 & 8.43 & 8.86 & 9.09 & 9.21 & 9.27 & 9.38 & 9.34 \\
\hline İzmir & 7.42 & 7.89 & 8.42 & 8.44 & 8.55 & 8.80 & 9.00 & 9.13 & 9.26 & 9.41 & 9.53 \\
\hline Kahramanmaraş & 6.27 & 6.94 & 7.26 & 7.38 & 7.51 & 7.80 & 8.02 & 8.26 & 8.39 & 8.58 & 8.73 \\
\hline Karabük & 7.08 & 7.70 & 7.97 & 8.12 & 8.26 & 8.45 & 8.65 & 8.80 & 8.94 & 8.99 & 9.09 \\
\hline Karaman & 6.63 & 7.24 & 7.55 & 7.68 & 7.80 & 8.03 & 8.21 & 8.35 & 8.45 & 8.60 & 8.71 \\
\hline Kars & 5.71 & 6.28 & 6.88 & 6.96 & 7.09 & 7.40 & 7.62 & 7.91 & 8.04 & 8.23 & 8.43 \\
\hline Kastamonu & 6.19 & 6.67 & 6.97 & 7.08 & 7.29 & 7.52 & 7.52 & 7.77 & 7.91 & 8.06 & 8.19 \\
\hline Kayseri & 7.13 & 7.76 & 8.05 & 8.34 & 8.47 & 8.67 & 8.85 & 8.98 & 9.11 & 9.25 & 9.34 \\
\hline Kirıkkale & 7.66 & 8.25 & 8.67 & 8.76 & 8.86 & 9.06 & 9.20 & 9.28 & 9.44 & 9.52 & 9.58 \\
\hline Kırklareli & 7.09 & 7.59 & 7.92 & 8.03 & 8.17 & 8.40 & 8.55 & 8.69 & 8.86 & 8.98 & 9.06 \\
\hline Kırşehir & 7.05 & 7.62 & 8.07 & 8.17 & 8.27 & 8.48 & 8.66 & 8.82 & 8.87 & 8.91 & 8.98 \\
\hline Kilis & 6.03 & 6.76 & 7.32 & 7.50 & 7.50 & 7.79 & 8.01 & 8.26 & 8.29 & 8.58 & 8.82 \\
\hline Kocaeli & 7.46 & 8.12 & 8.47 & 8.60 & 8.72 & 9.02 & 9.23 & 9.38 & 9.49 & 9.64 & 9.72 \\
\hline Konya & 6.95 & 7.46 & 7.73 & 7.88 & 7.99 & 8.22 & 8.41 & 8.55 & 8.69 & 8.82 & 8.92 \\
\hline Kütahya & 6.81 & 7.41 & 7.68 & 7.82 & 7.99 & 8.12 & 8.28 & 8.41 & 8.54 & 8.69 & 8.84 \\
\hline Malatya & 6.97 & 7.61 & 8.06 & 8.18 & 8.32 & 8.58 & 8.80 & 8.96 & 9.09 & 9.22 & 9.35 \\
\hline Manisa & 6.31 & 6.89 & 7.23 & 7.35 & 7.48 & 7.68 & 7.85 & 8.03 & 8.16 & 8.35 & 8.50 \\
\hline Mardin & 5.34 & 6.01 & 6.63 & 6.78 & 6.94 & 7.24 & 7.51 & 7.77 & 7.94 & 8.20 & 8.56 \\
\hline Mersin & 6.85 & 7.38 & 7.77 & 7.87 & 7.94 & 8.21 & 8.39 & 8.54 & 8.66 & 8.81 & 8.91 \\
\hline Muğla & 6.85 & 7.33 & 7.70 & 7.80 & 7.86 & 8.29 & 8.48 & 8.65 & 8.82 & 8.99 & 9.09 \\
\hline Muş & 4.77 & 5.78 & 6.41 & 6.57 & 6.72 & 7.01 & 7.27 & 7.53 & 7.71 & 7.96 & 8.41 \\
\hline Nevşehir & 6.81 & 7.41 & 7.78 & 7.88 & 8.01 & 8.16 & 8.36 & 8.49 & 8.56 & 8.63 & 8.73 \\
\hline Niğde & 6.52 & 7.15 & 7.58 & 7.66 & 7.78 & 7.99 & 8.14 & 8.32 & 8.42 & 8.53 & 8.64 \\
\hline Ordu & 6.08 & 6.60 & 6.86 & 6.99 & 7.13 & 7.42 & 7.64 & 7.83 & 7.97 & 8.15 & 8.29 \\
\hline Osmaniye & 6.84 & 7.47 & 7.81 & 7.94 & 8.09 & 8.36 & 8.56 & 8.81 & 8.96 & 9.12 & 9.24 \\
\hline Rize & 6.87 & 7.61 & 7.97 & 8.08 & 8.21 & 8.49 & 8.75 & 8.90 & 9.04 & 9.16 & 9.29 \\
\hline Sakarya & 6.89 & 7.49 & 7.86 & 7.98 & 8.10 & 8.37 & 8.52 & 8.62 & 8.81 & 8.94 & 9.05 \\
\hline Samsun & 6.36 & 6.91 & 7.24 & 7.40 & 7.54 & 7.83 & 8.02 & 8.19 & 8.32 & 8.47 & 8.59 \\
\hline Siirt & 5.59 & 6.52 & 7.21 & 7.32 & 7.51 & 7.77 & 8.02 & 8.28 & 8.44 & 8.76 & 9.07 \\
\hline Sinop & 5.96 & 6.50 & 6.87 & 7.00 & 7.11 & 7.32 & 7.52 & 7.71 & 7.85 & 7.95 & 8.09 \\
\hline Sivas & 6.73 & 7.26 & 7.51 & 7.78 & 7.91 & 8.09 & 8.29 & 8.48 & 8.65 & 8.70 & 8.87 \\
\hline Şanlıurfa & 4.60 & 5.65 & 6.21 & 6.33 & 6.43 & 6.79 & 7.03 & 7.27 & 7.44 & 7.67 & 8.11 \\
\hline Şırnak & 4.87 & 5.81 & 6.59 & 6.71 & 6.91 & 7.26 & 7.49 & 7.65 & 8.05 & 8.47 & 8.98 \\
\hline Tekirdağ & 7.13 & 7.67 & 7.99 & 8.09 & 8.22 & 8.53 & 8.68 & 8.82 & 8.94 & 9.09 & 9.19 \\
\hline Tokat & 6.20 & 6.78 & 7.08 & 7.26 & 7.41 & 7.64 & 7.85 & 8.04 & 8.20 & 8.36 & 8.50 \\
\hline Trabzon & 7.22 & 7.78 & 8.08 & 8.21 & 8.35 & 8.60 & 8.85 & 9.00 & 9.11 & 9.23 & 9.32 \\
\hline Tunceli & 6.88 & 7.23 & 7.93 & 8.03 & 8.23 & 8.64 & 8.88 & 9.00 & 9.14 & 9.31 & 9.46 \\
\hline Uşak & 6.71 & 7.32 & 7.69 & 7.79 & 7.90 & 8.06 & 8.19 & 8.27 & 8.37 & 8.52 & 8.64 \\
\hline Van & 5.08 & 5.92 & 6.38 & 6.55 & 6.73 & 7.08 & 7.35 & 7.61 & 7.81 & 8.12 & 8.50 \\
\hline Yalova & 7.16 & 7.73 & 8.04 & 8.20 & 8.30 & 8.72 & 8.79 & 8.79 & 8.87 & 8.88 & 8.82 \\
\hline Yozgat & 5.99 & 6.51 & 6.85 & 7.19 & 7.30 & 7.54 & 7.70 & 7.87 & 8.02 & 8.16 & 8.29 \\
\hline Zonguldak & 6.87 & 7.53 & 7.77 & 7.87 & 7.98 & 8.20 & 8.35 & 8.46 & 8.56 & 8.69 & 8.78 \\
\hline
\end{tabular}


Tablo 3. İl ve Yıl Kırılımında Genel Olarak Bütün Eğitimi Dikkate Alan Ortalama Okullaşma Okullaşma Yılı (Mean Years of Schooling)

\begin{tabular}{|c|c|c|c|c|c|c|c|c|c|c|c|}
\hline & 2009 & 2010 & 2011 & 2012 & 2013 & 2014 & 2015 & 2016 & 2017 & 2018 & 2019 \\
\hline Türkiye & 5.46 & 6.02 & 6.39 & 6.53 & 6.67 & 6.92 & 7.12 & 7.31 & 7.47 & 7.67 & 7.90 \\
\hline Adana & 6.15 & 6.72 & 7.03 & 7.04 & 7.26 & 7.49 & 7.69 & 7.86 & 8.00 & 8.17 & 8.33 \\
\hline Adiyaman & 4.92 & 5.47 & 5.84 & 6.19 & 6.36 & 6.58 & 6.80 & 7.06 & 7.23 & 7.46 & 7.81 \\
\hline Afyonkarahisar & 5.61 & 6.08 & 6.47 & 6.57 & 6.68 & 6.86 & 7.03 & 7.20 & 7.33 & 7.49 & 7.62 \\
\hline Ăgrn & 3.13 & 3.88 & 4.50 & 4.59 & 4.66 & 4.95 & 5.15 & 5.38 & 5.55 & 5.82 & 6.30 \\
\hline Aksaray & 5.14 & 5.65 & 6.12 & 6.25 & 6.36 & 6.61 & 6.73 & 6.91 & 7.03 & 7.18 & 7.33 \\
\hline Amasya & 5.74 & 6.23 & 6.51 & 6.66 & 6.81 & 7.05 & 7.23 & 7.45 & 7.60 & 7.81 & 7.98 \\
\hline Ankara & 7.83 & 8.21 & 8.45 & 8.56 & 8.71 & 9.00 & 9.20 & 9.32 & 9.43 & 9.55 & 9.62 \\
\hline Antalya & 6.47 & 6.94 & 7.22 & 7.36 & 7.43 & 7.76 & 7.99 & 8.14 & 8.31 & 8.41 & 8.45 \\
\hline Ardahan & 4.69 & 5.23 & 5.74 & 5.86 & 5.95 & 6.19 & 6.40 & 6.69 & 6.84 & 7.09 & 7.33 \\
\hline Artvin & 5.90 & 6.43 & 6.78 & 6.96 & 7.14 & 7.41 & 7.64 & 7.84 & 7.99 & 8.21 & 8.36 \\
\hline Aydın & 5.77 & 6.27 & 6.69 & 6.82 & 6.92 & 7.20 & 7.38 & 7.60 & 7.76 & 7.95 & 8.10 \\
\hline Balıkesir & 6.00 & 6.40 & 6.79 & 6.90 & 7.03 & 7.31 & 7.48 & 7.66 & 7.81 & 8.00 & 8.12 \\
\hline Bartın & 5.06 & 5.66 & 5.96 & 6.08 & 6.23 & 6.47 & 6.66 & 6.85 & 7.01 & 7.21 & 7.36 \\
\hline Batman & 4.16 & 5.21 & 5.66 & 5.81 & 5.95 & 6.18 & 6.43 & 6.68 & 6.90 & 7.18 & 7.83 \\
\hline Bayburt & 5.12 & 5.92 & 6.19 & 6.36 & 6.54 & 6.71 & 6.91 & 7.14 & 7.34 & 7.43 & 7.84 \\
\hline Bilecik & 6.38 & 6.90 & 7.24 & 7.34 & 7.45 & 7.66 & 7.82 & 7.99 & 8.14 & 8.30 & 8.43 \\
\hline Bingöl & 4.19 & 4.91 & 5.48 & 5.63 & 5.80 & 6.10 & 6.38 & 6.67 & 6.91 & 7.21 & 8.06 \\
\hline Bitlis & 4.16 & 4.90 & 5.42 & 5.56 & 5.67 & 5.93 & 6.15 & 6.45 & 6.61 & 6.97 & 7.55 \\
\hline Bolu & 6.08 & 6.55 & 6.85 & 6.99 & 7.13 & 7.34 & 7.53 & 7.73 & 7.89 & 8.01 & 8.11 \\
\hline Burdur & 5.85 & 6.29 & 6.53 & 6.66 & 6.80 & 7.00 & 7.19 & 7.38 & 7.57 & 7.79 & 7.94 \\
\hline Bursa & 6.47 & 6.97 & 7.28 & 7.40 & 7.51 & 7.82 & 8.00 & 8.15 & 8.32 & 8.43 & 8.54 \\
\hline Çanakkale & 6.05 & 6.46 & 6.84 & 6.98 & 7.14 & 7.38 & 7.58 & 7.75 & 7.94 & 8.13 & 8.28 \\
\hline Çankırı & 5.55 & 5.99 & 6.36 & 6.50 & 6.61 & 6.78 & 6.95 & 7.09 & 7.27 & 7.46 & 7.54 \\
\hline Çorum & 4.96 & 5.48 & 5.83 & 5.98 & 6.11 & 6.33 & 6.52 & 6.72 & 6.86 & 7.03 & 7.21 \\
\hline Denizli & 5.95 & 6.46 & 6.89 & 7.02 & 7.16 & 7.40 & 7.59 & 7.77 & 7.93 & 8.11 & 8.24 \\
\hline Diyarbakır & 4.10 & 4.83 & 5.23 & 5.42 & 5.56 & 5.84 & 6.07 & 6.31 & 6.52 & 6.83 & 7.38 \\
\hline Düzce & 5.65 & 6.27 & 6.61 & 6.74 & 6.89 & 7.16 & 7.37 & 7.57 & 7.76 & 7.93 & 8.09 \\
\hline Edirne & 6.20 & 6.58 & 6.87 & 6.99 & 7.13 & 7.36 & 7.51 & 7.69 & 7.85 & 8.02 & 8.15 \\
\hline Elazı̆̆ & 5.46 & 6.02 & 6.37 & 6.50 & 6.66 & 6.94 & 7.17 & 7.37 & 7.54 & 7.74 & 8.07 \\
\hline Erzincan & 5.68 & 6.20 & 6.49 & 6.65 & 6.86 & 7.06 & 7.34 & 7.49 & 7.69 & 7.82 & 8.15 \\
\hline Erzurum & 5.24 & 5.80 & 6.16 & 6.32 & 6.45 & 6.70 & 6.94 & 7.15 & 7.33 & 7.52 & 7.71 \\
\hline Eskişehir & 7.03 & 7.49 & 7.77 & 7.91 & 8.06 & 8.35 & 8.52 & 8.67 & 8.79 & 8.91 & 9.00 \\
\hline Gaziantep & 5.06 & 5.78 & 6.13 & 6.46 & 6.56 & 6.79 & 6.97 & 7.17 & 7.34 & 7.52 & 7.70 \\
\hline Giresun & 5.14 & 5.63 & 5.91 & 6.04 & 6.18 & 6.44 & 6.68 & 6.90 & 7.04 & 7.22 & 7.41 \\
\hline Gümüşhane & 5.30 & 5.78 & 6.17 & 6.31 & 6.50 & 6.76 & 6.96 & 6.93 & 6.87 & 7.54 & 7.40 \\
\hline Hakkâri & 4.11 & 4.75 & 5.57 & 5.75 & 5.88 & 6.17 & 6.44 & 6.53 & 6.77 & 7.37 & 8.38 \\
\hline Hatay & 5.44 & 5.95 & 6.30 & 6.41 & 6.54 & 6.80 & 7.01 & 7.24 & 7.37 & 7.54 & 7.70 \\
\hline Iğdır & 4.14 & 4.92 & 5.49 & 5.62 & 5.75 & 6.00 & 6.21 & 6.43 & 6.61 & 6.89 & 7.18 \\
\hline Isparta & 6.38 & 6.87 & 7.07 & 7.21 & 7.35 & 7.61 & 7.82 & 8.03 & 8.19 & 8.34 & 8.46 \\
\hline İstanbul & 6.83 & 7.32 & 7.59 & 7.71 & 7.85 & 8.24 & 8.47 & 8.59 & 8.67 & 8.80 & 8.82 \\
\hline İzmir & 6.84 & 7.26 & 7.73 & 7.80 & 7.91 & 8.16 & 8.36 & 8.51 & 8.66 & 8.83 & 8.96 \\
\hline Kahramanmaraş & 5.17 & 5.78 & 6.11 & 6.23 & 6.37 & 6.64 & 6.86 & 7.11 & 7.26 & 7.47 & 7.66 \\
\hline Karabük & 5.90 & 6.45 & 6.73 & 6.89 & 7.04 & 7.23 & 7.44 & 7.64 & 7.80 & 7.92 & 8.07 \\
\hline
\end{tabular}


PJESS'2021 / 8(2)

\begin{tabular}{|c|c|c|c|c|c|c|c|c|c|c|c|}
\hline Karaman & 5.76 & 6.30 & 6.61 & 6.76 & 6.89 & 7.11 & 7.30 & 7.48 & 7.61 & 7.79 & 7.92 \\
\hline Kars & 4.61 & 5.21 & 5.74 & 5.83 & 5.95 & 6.23 & 6.44 & 6.70 & 6.87 & 7.07 & 7.30 \\
\hline Kastamonu & 5.05 & 5.48 & 5.77 & 5.89 & 6.07 & 6.29 & 6.39 & 6.62 & 6.78 & 6.95 & 7.11 \\
\hline Kayseri & 6.10 & 6.66 & 6.95 & 7.24 & 7.38 & 7.59 & 7.79 & 7.95 & 8.10 & 8.26 & 8.39 \\
\hline Kırıkkale & 6.21 & 6.79 & 7.26 & 7.37 & 7.47 & 7.67 & 7.82 & 7.97 & 8.13 & 8.25 & 8.37 \\
\hline Kirklareli & 6.46 & 6.93 & 7.24 & 7.35 & 7.48 & 7.70 & 7.86 & 8.02 & 8.19 & 8.33 & 8.45 \\
\hline Kırşehir & 5.89 & 6.39 & 6.84 & 6.95 & 7.07 & 7.28 & 7.46 & 7.63 & 7.70 & 7.79 & 7.91 \\
\hline Kilis & 4.92 & 5.71 & 6.22 & 6.39 & 6.46 & 6.73 & 6.90 & 7.17 & 7.31 & 7.64 & 8.06 \\
\hline Kocaeli & 6.57 & 7.17 & 7.53 & 7.66 & 7.80 & 8.11 & 8.32 & 8.50 & 8.64 & 8.83 & 8.94 \\
\hline Konya & 5.89 & 6.33 & 6.60 & 6.75 & 6.88 & 7.11 & 7.31 & 7.48 & 7.64 & 7.80 & 7.93 \\
\hline Kütahya & 5.71 & 6.19 & 6.49 & 6.63 & 6.79 & 6.93 & 7.11 & 7.29 & 7.43 & 7.61 & 7.79 \\
\hline Malatya & 5.76 & 6.34 & 6.76 & 6.89 & 7.06 & 7.31 & 7.54 & 7.73 & 7.88 & 8.05 & 8.21 \\
\hline Manisa & 5.57 & 6.06 & 6.41 & 6.53 & 6.66 & 6.87 & 7.04 & 7.23 & 7.38 & 7.58 & 7.75 \\
\hline Mardin & 3.93 & 4.53 & 5.05 & 5.18 & 5.32 & 5.57 & 5.82 & 6.05 & 6.25 & 6.52 & 6.96 \\
\hline Mersin & 6.10 & 6.57 & 6.94 & 7.05 & 7.14 & 7.39 & 7.58 & 7.74 & 7.87 & 8.04 & 8.16 \\
\hline Muğla & 6.33 & 6.77 & 7.13 & 7.22 & 7.28 & 7.70 & 7.89 & 8.08 & 8.26 & 8.47 & 8.58 \\
\hline Muş & 3.38 & 4.24 & 4.79 & 4.93 & 5.04 & 5.28 & 5.50 & 5.76 & 5.97 & 6.22 & 7.04 \\
\hline Nevşehir & 5.77 & 6.30 & 6.70 & 6.81 & 6.95 & 7.12 & 7.31 & 7.48 & 7.59 & 7.70 & 7.82 \\
\hline Niğde & 5.52 & 6.09 & 6.53 & 6.62 & 6.75 & 6.96 & 7.12 & 7.33 & 7.46 & 7.61 & 7.76 \\
\hline Ordu & 5.05 & 5.55 & 5.78 & 5.92 & 6.05 & 6.31 & 6.52 & 6.73 & 6.88 & 7.09 & 7.25 \\
\hline Osmaniye & 5.79 & 6.38 & 6.69 & 6.83 & 6.98 & 7.25 & 7.47 & 7.74 & 7.90 & 8.10 & 8.26 \\
\hline Rize & 5.66 & 6.29 & 6.64 & 6.78 & 6.92 & 7.18 & 7.45 & 7.69 & 7.87 & 8.05 & 8.25 \\
\hline Sakarya & 5.97 & 6.51 & 6.87 & 7.00 & 7.14 & 7.40 & 7.58 & 7.73 & 7.93 & 8.10 & 8.25 \\
\hline Samsun & 5.52 & 6.01 & 6.33 & 6.49 & 6.64 & 6.91 & 7.12 & 7.33 & 7.47 & 7.65 & 7.80 \\
\hline Siirt & 3.93 & 4.73 & 5.30 & 5.40 & 5.55 & 5.88 & 6.02 & 6.26 & 6.46 & 6.78 & 7.29 \\
\hline Sinop & 5.15 & 5.62 & 5.96 & 6.08 & 6.19 & 6.40 & 6.60 & 6.81 & 6.97 & 7.11 & 7.26 \\
\hline Sivas & 5.52 & 6.02 & 6.27 & 6.55 & 6.68 & 6.84 & 7.05 & 7.26 & 7.45 & 7.54 & 7.76 \\
\hline Şanlıurfa & 3.31 & 4.12 & 4.56 & 4.66 & 4.76 & 5.06 & 5.28 & 5.49 & 5.69 & 5.92 & 6.46 \\
\hline Şırnak & 3.29 & 4.08 & 4.72 & 4.83 & 4.97 & 5.27 & 5.44 & 5.59 & 6.01 & 6.44 & 7.34 \\
\hline Tekirdağ & 6.51 & 7.01 & 7.33 & 7.43 & 7.56 & 7.84 & 8.00 & 8.16 & 8.29 & 8.45 & 8.58 \\
\hline Tokat & 5.20 & 5.71 & 6.00 & 6.16 & 6.29 & 6.51 & 6.72 & 6.92 & 7.09 & 7.26 & 7.43 \\
\hline Trabzon & 6.01 & 6.52 & 6.81 & 6.95 & 7.10 & 7.34 & 7.61 & 7.83 & 7.98 & 8.14 & 8.28 \\
\hline Tunceli & 5.74 & 6.14 & 6.76 & 6.88 & 7.09 & 7.45 & 7.69 & 7.85 & 8.03 & 8.24 & 8.45 \\
\hline Uşak & 5.80 & 6.32 & 6.70 & 6.81 & 6.93 & 7.11 & 7.26 & 7.40 & 7.51 & 7.68 & 7.83 \\
\hline Van & 3.81 & 4.51 & 4.88 & 5.04 & 5.19 & 5.49 & 5.73 & 5.96 & 6.18 & 6.47 & 6.88 \\
\hline Yalova & 6.48 & 6.98 & 7.28 & 7.43 & 7.53 & 7.92 & 8.02 & 8.06 & 8.14 & 8.18 & 8.16 \\
\hline Yozgat & 5.03 & 5.48 & 5.80 & 6.11 & 6.21 & 6.41 & 6.57 & 6.76 & 6.90 & 7.05 & 7.22 \\
\hline Zonguldak & 5.81 & 6.32 & 6.57 & 6.68 & 6.79 & 7.01 & 7.17 & 7.32 & 7.44 & 7.60 & 7.72 \\
\hline
\end{tabular}


Tablo 4. İl ve Yıl Kırılımında Kadınlar İçin Liseye Kadar Olan Eğitimi Dikkate Alan

Ortalama Okullaşma Yılı (Mean Years of Schooling-Women-High School)

\begin{tabular}{|c|c|c|c|c|c|c|c|c|c|c|c|}
\hline & 2009 & 2010 & 2011 & 2012 & 2013 & 2014 & 2015 & 2016 & 2017 & 2018 & 2019 \\
\hline Türkiye & 4.24 & 4.71 & 5.03 & 5.15 & 5.24 & 5.45 & 5.60 & 5.79 & 5.93 & 6.11 & 6.38 \\
\hline Adana & 5.11 & 5.57 & 5.82 & 5.83 & 6.01 & 6.20 & 6.35 & 6.50 & 6.63 & 6.78 & 6.93 \\
\hline Adiyaman & 3.47 & 4.04 & 4.35 & 4.66 & 4.78 & 4.97 & 5.14 & 5.39 & 5.55 & 5.81 & 6.22 \\
\hline Afyonkarahisar & 4.41 & 4.78 & 5.17 & 5.26 & 5.35 & 5.51 & 5.65 & 5.81 & 5.93 & 6.09 & 6.22 \\
\hline Ağrn & 1.84 & 2.47 & 2.88 & 2.96 & 2.99 & 3.18 & 3.33 & 3.50 & 3.67 & 3.87 & 4.38 \\
\hline Aksaray & 4.05 & 4.48 & 4.90 & 5.02 & 5.11 & 5.30 & 5.44 & 5.61 & 5.73 & 5.88 & 6.05 \\
\hline Amasya & 4.61 & 5.02 & 5.27 & 5.41 & 5.50 & 5.70 & 5.85 & 6.07 & 6.20 & 6.33 & 6.49 \\
\hline Ankara & 6.46 & 6.79 & 6.97 & 7.07 & 7.15 & 7.37 & 7.51 & 7.62 & 7.71 & 7.81 & 7.87 \\
\hline Antalya & 5.51 & 5.93 & 6.16 & 6.25 & 6.30 & 6.55 & 6.71 & 6.84 & 6.98 & 7.07 & 7.11 \\
\hline Ardahan & 3.45 & 3.97 & 4.36 & 4.46 & 4.53 & 4.70 & 4.87 & 5.10 & 5.24 & 5.46 & 5.71 \\
\hline Artvin & 4.58 & 4.98 & 5.27 & 5.42 & 5.55 & 5.77 & 5.97 & 6.17 & 6.30 & 6.52 & 6.68 \\
\hline Aydın & 4.87 & 5.28 & 5.66 & 5.77 & 5.84 & 6.07 & 6.21 & 6.42 & 6.55 & 6.72 & 6.86 \\
\hline Balıkesir & 5.06 & 5.38 & 5.72 & 5.82 & 5.91 & 6.14 & 6.27 & 6.44 & 6.56 & 6.73 & 6.85 \\
\hline Bartın & 3.98 & 4.40 & 4.69 & 4.80 & 4.91 & 5.12 & 5.29 & 5.50 & 5.64 & 5.84 & 5.99 \\
\hline Batman & 2.43 & 3.33 & 3.70 & 3.82 & 3.91 & 4.12 & 4.33 & 4.55 & 4.78 & 5.07 & 5.95 \\
\hline Bayburt & 3.60 & 4.36 & 4.57 & 4.72 & 4.87 & 5.02 & 5.24 & 5.46 & 5.56 & 5.69 & 6.05 \\
\hline Bilecik & 5.29 & 5.68 & 6.00 & 6.11 & 6.19 & 6.37 & 6.49 & 6.65 & 6.79 & 6.94 & 7.08 \\
\hline Bingöl & 2.66 & 3.31 & 3.78 & 3.90 & 4.02 & 4.27 & 4.52 & 4.81 & 5.04 & 5.37 & 6.53 \\
\hline Bitlis & 2.50 & 3.12 & 3.48 & 3.60 & 3.68 & 3.88 & 4.04 & 4.31 & 4.49 & 4.76 & 5.65 \\
\hline Bolu & 4.91 & 5.31 & 5.56 & 5.68 & 5.78 & 5.95 & 6.11 & 6.30 & 6.43 & 6.55 & 6.66 \\
\hline Burdur & 4.76 & 5.12 & 5.35 & 5.46 & 5.56 & 5.73 & 5.88 & 6.07 & 6.20 & 6.39 & 6.53 \\
\hline Bursa & 5.44 & 5.85 & 6.12 & 6.23 & 6.31 & 6.57 & 6.71 & 6.85 & 7.00 & 7.12 & 7.22 \\
\hline Çanakl & 5.14 & 5.45 & 5.78 & 5.90 & 6.00 & 6.21 & 6.36 & 6.55 & 6.68 & 6.85 & 7.00 \\
\hline Çankırı & 4.30 & 4.68 & 5.03 & 5.15 & 5.24 & 5.36 & 5.49 & 5.66 & 5.79 & 6.03 & 6.09 \\
\hline Çorum & 3.91 & 4.35 & 4.65 & 4.78 & 4.87 & 5.05 & 5.22 & 5.43 & 5.55 & 5.72 & 5.88 \\
\hline & 4.98 & 5.41 & 5.80 & 5.93 & 6.03 & 6.23 & 6.38 & 6.56 & 6.70 & 6.87 & 6.99 \\
\hline Diyarba & 2.61 & 3.20 & 3.50 & 3.66 & 3.75 & 3.97 & 4.14 & 4.34 & 4.53 & 4.81 & 5.45 \\
\hline Düzce & 4.55 & 5.03 & 5.23 & 5.46 & 5.58 & 5.81 & 6.00 & 6.20 & 6.35 & 6.51 & 6.67 \\
\hline Edirne & 5.31 & 5.65 & 5.87 & 5.97 & 6.05 & 6.23 & 6.35 & 6.5 & 6.65 & 6.81 & 6.94 \\
\hline Elazı̆̆ & 3.87 & 4.36 & 4.64 & 4.76 & 4.87 & 5.10 & 5.27 & 5.45 & 5.60 & 5.82 & 6.22 \\
\hline Erzincar & 4.24 & 4.71 & 4.97 & 5.12 & 5.24 & 5.41 & 5.62 & 5.8 & 5.97 & 6.13 & 6.43 \\
\hline Erzurum & 3.69 & 4.20 & 4.52 & 4.64 & 4.73 & 4.91 & 5.10 & 5.29 & 5.45 & 5.63 & 5.81 \\
\hline Eskişehir & 5.81 & 6.19 & 6.43 & 6.55 & 6.64 & 6.88 & 7.01 & 7.15 & 7.25 & 7.36 & 7.44 \\
\hline Gaziantep & 3.88 & 4.47 & 4.80 & 5.09 & 5.16 & 5.38 & 5.54 & 5.73 & 5.90 & 6.07 & 6.24 \\
\hline Giresun & 3.86 & 4.29 & 4.52 & 4.63 & 4.73 & 4.95 & 5.14 & 5.37 & 5.49 & 5.67 & 5.86 \\
\hline Gümüşhane & 3.93 & 4.28 & 4.67 & 4.79 & 4.93 & 5.08 & 5.33 & 5.42 & 5.36 & 5.91 & 5.87 \\
\hline Hakkâri & 2.33 & 2.97 & 3.52 & 3.67 & 3.71 & 3.92 & 4.09 & 4.25 & 4.48 & 4.96 & 6.81 \\
\hline Hatay & 4.43 & 4.88 & 5.19 & 5.30 & 5.38 & 5.60 & 5.77 & 5.96 & 6.09 & 6.25 & 6.42 \\
\hline Iğdır & 2.97 & 3.65 & 4.11 & 4.23 & 4.30 & 4.51 & 4.67 & 4.90 & 5.03 & 5.29 & 5.64 \\
\hline Isparta & 5.16 & 5.54 & 5.76 & 5.88 & 5.98 & 6.18 & 6.34 & 6.56 & 6.68 & 6.83 & 6.94 \\
\hline İstanbul & 5.88 & 6.29 & 6.51 & 6.60 & 6.68 & 6.98 & 7.13 & 7.23 & 7.29 & 7.40 & 7.44 \\
\hline İzmir & 5.88 & 6.22 & 6.57 & 6.66 & 6.74 & 6.93 & 7.08 & 7.22 & 7.33 & 7.47 & 7.59 \\
\hline Kahramanr & 3.90 & 4.44 & 4.73 & 4.84 & 4.96 & 5.19 & 5.37 & 5.60 & 5.75 & 5.95 & 6.14 \\
\hline Karabük & 4.60 & 5.05 & 5.30 & 5.43 & 5.53 & 5.69 & 5.85 & 6.05 & 6.18 & 6.34 & 6.52 \\
\hline
\end{tabular}


PJESS'2021 / 8(2)

\begin{tabular}{|c|c|c|c|c|c|c|c|c|c|c|c|}
\hline Karaman & 4.77 & 5.20 & 5.49 & 5.63 & 5.72 & 5.91 & 6.06 & 6.26 & 6.37 & 6.55 & 6.68 \\
\hline Kars & 3.32 & 3.94 & 4.34 & 4.42 & 4.51 & 4.71 & 4.87 & 5.08 & 5.24 & 5.43 & 5.66 \\
\hline Kastamonu & 3.84 & 4.20 & 4.46 & 4.57 & 4.68 & 4.86 & 5.01 & 5.21 & 5.34 & 5.50 & 5.67 \\
\hline Kayseri & 4.84 & 5.30 & 5.56 & 5.82 & 5.92 & 6.12 & 6.29 & 6.45 & 6.59 & 6.73 & 6.87 \\
\hline Kırıkkale & 4.64 & 5.17 & 5.68 & 5.78 & 5.85 & 6.01 & 6.14 & 6.29 & 6.41 & 6.55 & 6.70 \\
\hline Kırklareli & 5.61 & 6.02 & 6.27 & 6.36 & 6.45 & 6.62 & 6.74 & 6.90 & 7.01 & 7.15 & 7.29 \\
\hline Kırşehir & 4.60 & 5.01 & 5.43 & 5.52 & 5.60 & 5.79 & 5.91 & 6.08 & 6.12 & 6.24 & 6.36 \\
\hline Kilis & 3.74 & 4.58 & 5.00 & 5.14 & 5.21 & 5.44 & 5.52 & 5.78 & 5.93 & 6.25 & 6.83 \\
\hline Kocaeli & 5.39 & 5.91 & 6.23 & 6.35 & 6.44 & 6.72 & 6.89 & 7.06 & 7.19 & 7.38 & 7.50 \\
\hline Konya & 4.68 & 5.04 & 5.28 & 5.41 & 5.51 & 5.71 & 5.87 & 6.04 & 6.18 & 6.34 & 6.48 \\
\hline Kütahya & 4.49 & 4.84 & 5.17 & 5.28 & 5.38 & 5.54 & 5.69 & 5.88 & 6.01 & 6.18 & 6.34 \\
\hline Malatya & 4.38 & 4.87 & 5.23 & 5.35 & 5.46 & 5.68 & 5.87 & 6.05 & 6.19 & 6.36 & 6.53 \\
\hline Manisa & 4.67 & 5.06 & 5.39 & 5.50 & 5.60 & 5.78 & 5.92 & 6.10 & 6.23 & 6.41 & 6.57 \\
\hline Mardin & 2.49 & 3.01 & 3.40 & 3.50 & 3.58 & 3.78 & 3.96 & 4.14 & 4.33 & 4.55 & 5.05 \\
\hline Mersin & 5.12 & 5.51 & 5.83 & 5.92 & 5.98 & 6.18 & 6.33 & 6.47 & 6.58 & 6.73 & 6.85 \\
\hline Muğla & 5.48 & 5.84 & 6.15 & 6.23 & 6.25 & 6.59 & 6.72 & 6.89 & 7.05 & 7.23 & 7.33 \\
\hline Muş & 1.87 & 2.56 & 2.98 & 3.10 & 3.15 & 3.33 & 3.48 & 3.72 & 3.91 & 4.13 & 5.29 \\
\hline Nevşehir & 4.61 & 5.07 & 5.45 & 5.56 & 5.66 & 5.82 & 5.97 & 6.14 & 6.26 & 6.38 & 6.52 \\
\hline Niğde & 4.36 & 4.83 & 5.26 & 5.35 & 5.45 & 5.63 & 5.77 & 5.97 & 6.10 & 6.26 & 6.42 \\
\hline Ordu & 3.88 & 4.34 & 4.54 & 4.67 & 4.76 & 4.96 & 5.13 & 5.32 & 5.46 & 5.65 & 5.82 \\
\hline Osmaniye & 4.59 & 5.10 & 5.37 & 5.48 & 5.59 & 5.82 & 6.03 & 6.27 & 6.41 & 6.61 & 6.79 \\
\hline Rize & 4.35 & 4.85 & 5.15 & 5.27 & 5.38 & 5.58 & 5.81 & 6.09 & 6.25 & 6.46 & 6.68 \\
\hline Sakarya & 4.88 & 5.33 & 5.65 & 5.77 & 5.87 & 6.10 & 6.26 & 6.43 & 6.61 & 6.78 & 6.93 \\
\hline Samsun & 4.50 & 4.91 & 5.19 & 5.33 & 5.44 & 5.66 & 5.84 & 6.04 & 6.17 & 6.34 & 6.49 \\
\hline Siirt & 2.14 & 2.83 & 3.20 & 3.29 & 3.37 & 3.71 & 3.71 & 3.91 & 4.10 & 4.35 & 5.06 \\
\hline Sinop & 4.19 & 4.59 & 4.88 & 4.98 & 5.05 & 5.23 & 5.39 & 5.60 & 5.72 & 5.88 & 6.01 \\
\hline Sivas & 4.13 & 4.57 & 4.81 & 5.07 & 5.16 & 5.29 & 5.47 & 5.67 & 5.83 & 5.94 & 6.17 \\
\hline Şanlıurfa & 1.98 & 2.55 & 2.84 & 2.92 & 2.97 & 3.20 & 3.35 & 3.52 & 3.70 & 3.91 & 4.52 \\
\hline Şırnak & 1.61 & 2.29 & 2.72 & 2.81 & 2.87 & 3.06 & 3.16 & 3.29 & 3.60 & 3.93 & 5.25 \\
\hline Tekirdağ & 5.64 & 6.07 & 6.34 & 6.44 & 6.51 & 6.74 & 6.86 & 7.01 & 7.11 & 7.26 & 7.39 \\
\hline Tokat & 4.09 & 4.52 & 4.76 & 4.91 & 4.99 & 5.17 & 5.34 & 5.52 & 5.66 & 5.83 & 6.00 \\
\hline Trabzon & 4.61 & 5.04 & 5.29 & 5.42 & 5.53 & 5.73 & 5.96 & 6.19 & 6.34 & 6.51 & 6.66 \\
\hline Tunceli & 4.27 & 4.74 & 5.16 & 5.28 & 5.43 & 5.69 & 5.82 & 6.01 & 6.16 & 6.35 & 6.60 \\
\hline Uşak & 4.73 & 5.15 & 5.50 & 5.61 & 5.70 & 5.86 & 6.00 & 6.16 & 6.27 & 6.43 & 6.57 \\
\hline Van & 2.38 & 2.95 & 3.16 & 3.31 & 3.41 & 3.63 & 3.80 & 3.98 & 4.19 & 4.42 & 4.83 \\
\hline Yalova & 5.55 & 5.97 & 6.20 & 6.32 & 6.38 & 6.70 & 6.77 & 6.82 & 6.88 & 6.91 & 6.90 \\
\hline Yozgat & 3.99 & 4.37 & 4.63 & 4.90 & 4.97 & 5.12 & 5.24 & 5.41 & 5.53 & 5.66 & 5.84 \\
\hline Zonguldak & 4.61 & 4.95 & 5.18 & 5.29 & 5.37 & 5.55 & 5.69 & 5.85 & 5.96 & 6.12 & 6.24 \\
\hline
\end{tabular}


Tablo 5. İl ve Yıl Kırılımında Erkekler İçin Liseye Kadar Olan Eğitimi Dikkate Alan Ortalama Okullaşma Yılı (Mean Years of Schooling-Men-High school)

\begin{tabular}{|c|c|c|c|c|c|c|c|c|c|c|c|}
\hline & 2009 & 2010 & 2011 & 2012 & 2013 & 2014 & 2015 & 2016 & 2017 & 2018 & 2019 \\
\hline Türkiye & 6.15 & 6.73 & 7.08 & 7.20 & 7.28 & 7.50 & 7.65 & 7.79 & 7.89 & 8.03 & 8.17 \\
\hline Adana & 6.55 & 7.15 & 7.44 & 7.43 & 7.60 & 7.79 & 7.94 & 8.08 & 8.16 & 8.29 & 8.42 \\
\hline Adiyaman & 6.00 & 6.47 & 6.81 & 7.15 & 7.24 & 7.42 & 7.58 & 7.76 & 7.85 & 8.01 & 8.23 \\
\hline Afyonkarahisar & 6.37 & 6.90 & 7.23 & 7.31 & 7.37 & 7.52 & 7.64 & 7.76 & 7.84 & 7.95 & 8.03 \\
\hline Ăgrı & 4.09 & 4.91 & 5.61 & 5.70 & 5.74 & 6.07 & 6.26 & 6.49 & 6.60 & 6.87 & 7.25 \\
\hline Aksaray & 5.85 & 6.39 & 6.85 & 6.95 & 6.99 & 7.17 & 7.29 & 7.41 & 7.47 & 7.58 & 7.66 \\
\hline Amasya & 6.36 & 6.87 & 7.12 & 7.25 & 7.35 & 7.58 & 7.70 & 7.85 & 7.95 & 8.11 & 8.24 \\
\hline Ankara & 7.81 & 8.17 & 8.35 & 8.43 & 8.49 & 8.75 & 8.86 & 8.93 & 8.98 & 9.05 & 9.07 \\
\hline Antalya & 6.64 & 7.11 & 7.35 & 7.48 & 7.51 & 7.84 & 8.02 & 8.13 & 8.24 & 8.31 & 8.31 \\
\hline Ardahan & 5.55 & 6.08 & 6.58 & 6.67 & 6.72 & 6.96 & 7.13 & 7.39 & 7.50 & 7.72 & 7.90 \\
\hline Artvin & 6.75 & 7.34 & 7.64 & 7.79 & 7.89 & 8.13 & 8.30 & 8.43 & 8.53 & 8.68 & 8.77 \\
\hline Aydın & 6.08 & 6.60 & 6.98 & 7.08 & 7.14 & 7.38 & 7.51 & 7.70 & 7.81 & 7.95 & 8.04 \\
\hline Balıkesir & 6.36 & 6.78 & 7.14 & 7.24 & 7.31 & 7.55 & 7.68 & 7.81 & 7.91 & 8.05 & 8.13 \\
\hline Bartın & 5.76 & 6.50 & 6.75 & 6.84 & 6.94 & 7.14 & 7.29 & 7.41 & 7.52 & 7.69 & 7.81 \\
\hline Batman & 5.54 & 6.67 & 7.08 & 7.19 & 7.28 & 7.46 & 7.65 & 7.85 & 7.97 & 8.17 & 8.53 \\
\hline Bayburt & 6.20 & 6.79 & 7.20 & 7.33 & 7.42 & 7.53 & 7.60 & 7.85 & 8.00 & 8.06 & 8.34 \\
\hline Bilecik & 6.93 & 7.46 & 7.74 & 7.82 & 7.86 & 8.04 & 8.13 & 8.23 & 8.33 & 8.45 & 8.53 \\
\hline Bingöl & 5.37 & 6.12 & 6.64 & 6.78 & 6.88 & 7.15 & 7.35 & 7.56 & 7.71 & 7.92 & 8.42 \\
\hline Bitlis & 5.39 & 6.20 & 6.70 & 6.84 & 6.91 & 7.15 & 7.33 & 7.59 & 7.69 & 7.97 & 8.27 \\
\hline Bolu & 6.65 & 7.13 & 7.37 & 7.48 & 7.55 & 7.75 & 7.86 & 8.00 & 8.10 & 8.17 & 8.20 \\
\hline Burdur & 6.41 & 6.88 & 7.07 & 7.17 & 7.25 & 7.42 & 7.56 & 7.68 & 7.82 & 7.96 & 8.05 \\
\hline Bursa & 6.84 & 7.37 & 7.64 & 7.73 & 7.79 & 8.07 & 8.18 & 8.28 & 8.40 & 8.46 & 8.51 \\
\hline Çanakkale & 6.33 & 6.75 & 7.09 & 7.19 & 7.29 & 7.50 & 7.63 & 7.71 & 7.86 & 8.00 & 8.09 \\
\hline Çankırı & 6.36 & 6.83 & 7.15 & 7.28 & 7.32 & 7.47 & 7.59 & 7.66 & 7.79 & 7.93 & 7.97 \\
\hline Çorum & 5.62 & 6.18 & 6.51 & 6.64 & 6.72 & 6.94 & 7.08 & 7.23 & 7.32 & 7.45 & 7.59 \\
\hline Denizli & 6.32 & 6.86 & 7.24 & 7.35 & 7.42 & 7.63 & 7.77 & 7.90 & 8.01 & 8.14 & 8.21 \\
\hline Diyarbakır & 5.18 & 5.99 & 6.38 & 6.55 & 6.64 & 6.91 & 7.08 & 7.31 & 7.45 & 7.70 & 8.11 \\
\hline Düzce & 6.29 & 6.99 & 7.28 & 7.38 & 7.48 & 7.70 & 7.84 & 7.97 & 8.09 & 8.20 & 8.30 \\
\hline Edirne & 6.44 & 6.82 & 7.08 & 7.17 & 7.26 & 7.48 & 7.58 & 7.72 & 7.83 & 7.95 & 8.04 \\
\hline Elazı̆̆ & 6.50 & 6.95 & 7.40 & 7.50 & 7.59 & 7.85 & 8.03 & 8.17 & 8.26 & 8.39 & 8.58 \\
\hline Erzincan & 6.53 & 7.03 & 7.28 & 7.40 & 7.51 & 7.68 & 7.90 & 7.97 & 8.08 & 8.15 & 8.40 \\
\hline Erzurum & 6.19 & 6.74 & 7.05 & 7.20 & 7.27 & 7.51 & 7.71 & 7.87 & 7.99 & 8.13 & 8.30 \\
\hline Eskişehir & 7.38 & 7.84 & 8.05 & 8.15 & 8.21 & 8.45 & 8.55 & 8.64 & 8.71 & 8.78 & 8.81 \\
\hline Gaziantep & 5.79 & 6.57 & 6.89 & 7.21 & 7.25 & 7.44 & 7.54 & 7.69 & 7.79 & 7.94 & 8.07 \\
\hline Giresun & 5.99 & 6.48 & 6.74 & 6.85 & 6.94 & 7.18 & 7.38 & 7.54 & 7.61 & 7.75 & 7.87 \\
\hline Gümüşhane & 6.26 & 6.58 & 7.05 & 7.16 & 7.26 & 7.43 & 7.61 & 7.44 & 7.31 & 7.98 & 7.71 \\
\hline Hakkâri & 5.42 & 6.14 & 6.95 & 7.07 & 7.19 & 7.46 & 7.69 & 7.73 & 7.89 & 8.30 & 8.66 \\
\hline Hatay & 5.96 & 6.47 & 6.80 & 6.89 & 6.97 & 7.22 & 7.39 & 7.58 & 7.65 & 7.76 & 7.88 \\
\hline Iğdır & 4.88 & 5.70 & 6.26 & 6.36 & 6.45 & 6.67 & 6.84 & 7.03 & 7.17 & 7.42 & 7.58 \\
\hline Isparta & 6.87 & 7.35 & 7.50 & 7.61 & 7.69 & 7.92 & 8.07 & 8.20 & 8.29 & 8.38 & 8.44 \\
\hline İstanbul & 6.85 & 7.34 & 7.56 & 7.66 & 7.72 & 8.10 & 8.25 & 8.34 & 8.37 & 8.44 & 8.40 \\
\hline İzmir & 6.89 & 7.33 & 7.78 & 7.80 & 7.86 & 8.07 & 8.20 & 8.31 & 8.40 & 8.52 & 8.61 \\
\hline Kahramanmaraş & 5.96 & 6.59 & 6.88 & 6.98 & 7.07 & 7.31 & 7.48 & 7.70 & 7.79 & 7.95 & 8.08 \\
\hline Karabük & 6.68 & 7.25 & 7.47 & 7.59 & 7.65 & 7.81 & 7.95 & 8.05 & 8.14 & 8.21 & 8.28 \\
\hline
\end{tabular}


PJESS'2021 / 8(2)

\begin{tabular}{|c|c|c|c|c|c|c|c|c|c|c|c|}
\hline Karaman & 6.28 & 6.86 & 7.12 & 7.23 & 7.30 & 7.49 & 7.62 & 7.75 & 7.81 & 7.93 & 8.02 \\
\hline Kars & 5.46 & 6.00 & 6.53 & 6.59 & 6.67 & 6.95 & 7.12 & 7.37 & 7.47 & 7.65 & 7.83 \\
\hline Kastamonu & 5.90 & 6.35 & 6.62 & 6.71 & 6.83 & 7.02 & 7.03 & 7.25 & 7.36 & 7.49 & 7.60 \\
\hline Kayseri & 6.69 & 7.27 & 7.52 & 7.78 & 7.85 & 8.02 & 8.14 & 8.26 & 8.35 & 8.46 & 8.53 \\
\hline Kırıkkale & 7.27 & 7.79 & 8.17 & 8.24 & 8.29 & 8.44 & 8.52 & 8.57 & 8.67 & 8.74 & 8.79 \\
\hline Kirklareli & 6.75 & 7.21 & 7.48 & 7.57 & 7.66 & 7.85 & 7.97 & 8.08 & 8.20 & 8.30 & 8.37 \\
\hline Kırşehir & 6.65 & 7.18 & 7.58 & 7.65 & 7.70 & 7.86 & 7.97 & 8.09 & 8.10 & 8.14 & 8.19 \\
\hline Kilis & 5.72 & 6.42 & 6.92 & 7.08 & 7.02 & 7.27 & 7.43 & 7.66 & 7.66 & 7.90 & 8.11 \\
\hline Kocaeli & 7.03 & 7.65 & 7.95 & 8.05 & 8.12 & 8.37 & 8.52 & 8.63 & 8.71 & 8.83 & 8.89 \\
\hline Konya & 6.53 & 7.00 & 7.23 & 7.35 & 7.41 & 7.60 & 7.74 & 7.86 & 7.95 & 8.06 & 8.13 \\
\hline Kütahya & 6.47 & 7.03 & 7.27 & 7.39 & 7.49 & 7.60 & 7.72 & 7.82 & 7.91 & 8.04 & 8.16 \\
\hline Malatya & 6.55 & 7.14 & 7.52 & 7.62 & 7.70 & 7.90 & 8.06 & 8.20 & 8.29 & 8.40 & 8.50 \\
\hline Manisa & 6.01 & 6.56 & 6.87 & 6.97 & 7.06 & 7.23 & 7.36 & 7.51 & 7.61 & 7.77 & 7.89 \\
\hline Mardin & 5.10 & 5.74 & 6.28 & 6.41 & 6.51 & 6.77 & 6.98 & 7.21 & 7.35 & 7.57 & 7.90 \\
\hline Mersin & 6.44 & 6.95 & 7.28 & 7.37 & 7.40 & 7.63 & 7.76 & 7.89 & 7.97 & 8.10 & 8.18 \\
\hline Muğla & 6.44 & 6.88 & 7.20 & 7.28 & 7.30 & 7.65 & 7.80 & 7.94 & 8.06 & 8.20 & 8.28 \\
\hline Muş & 4.60 & 5.57 & 6.11 & 6.24 & 6.33 & 6.59 & 6.79 & 7.03 & 7.16 & 7.38 & 7.81 \\
\hline Nevşehir & 6.49 & 7.05 & 7.38 & 7.46 & 7.53 & 7.66 & 7.80 & 7.91 & 7.95 & 8.01 & 8.06 \\
\hline Niğde & 6.17 & 6.77 & 7.15 & 7.22 & 7.30 & 7.47 & 7.59 & 7.74 & 7.82 & 7.93 & 8.02 \\
\hline Ordu & 5.81 & 6.29 & 6.51 & 6.64 & 6.73 & 6.98 & 7.16 & 7.33 & 7.44 & 7.61 & 7.73 \\
\hline Osmaniye & 6.49 & 7.09 & 7.38 & 7.49 & 7.59 & 7.82 & 7.96 & 8.17 & 8.27 & 8.41 & 8.51 \\
\hline Rize & 6.51 & 7.20 & 7.51 & 7.60 & 7.67 & 7.92 & 8.12 & 8.24 & 8.34 & 8.45 & 8.55 \\
\hline Sakarya & 6.53 & 7.10 & 7.41 & 7.51 & 7.58 & 7.82 & 7.92 & 8.01 & 8.15 & 8.26 & 8.34 \\
\hline Samsun & 6.00 & 6.51 & 6.80 & 6.94 & 7.03 & 7.28 & 7.42 & 7.56 & 7.65 & 7.77 & 7.87 \\
\hline Siirt & 5.28 & 6.19 & 6.78 & 6.87 & 6.97 & 7.18 & 7.37 & 7.58 & 7.70 & 7.96 & 8.28 \\
\hline Sinop & 5.65 & 6.15 & 6.48 & 6.60 & 6.66 & 6.85 & 7.00 & 7.16 & 7.27 & 7.38 & 7.49 \\
\hline Sivas & 6.35 & 6.85 & 7.05 & 7.30 & 7.38 & 7.52 & 7.68 & 7.84 & 7.96 & 8.01 & 8.15 \\
\hline Şanlıurfa & 4.39 & 5.40 & 5.90 & 6.00 & 6.06 & 6.39 & 6.58 & 6.79 & 6.92 & 7.14 & 7.55 \\
\hline Şırnak & 4.60 & 5.55 & 6.22 & 6.32 & 6.44 & 6.75 & 6.93 & 7.10 & 7.42 & 7.76 & 8.27 \\
\hline Tekirdağ & 6.78 & 7.29 & 7.57 & 7.65 & 7.73 & 8.00 & 8.11 & 8.24 & 8.33 & 8.46 & 8.54 \\
\hline Tokat & 5.87 & 6.41 & 6.67 & 6.83 & 6.92 & 7.12 & 7.28 & 7.45 & 7.56 & 7.71 & 7.83 \\
\hline Trabzon & 6.74 & 7.26 & 7.51 & 7.62 & 7.69 & 7.92 & 8.10 & 8.23 & 8.30 & 8.40 & 8.47 \\
\hline Tunceli & 6.48 & 6.84 & 7.41 & 7.49 & 7.60 & 7.93 & 8.11 & 8.21 & 8.32 & 8.46 & 8.59 \\
\hline Uşak & 6.37 & 6.95 & 7.27 & 7.36 & 7.42 & 7.55 & 7.64 & 7.71 & 7.77 & 7.90 & 7.99 \\
\hline Van & 4.82 & 5.63 & 6.04 & 6.20 & 6.32 & 6.62 & 6.83 & 7.07 & 7.22 & 7.50 & 7.85 \\
\hline Yalova & 6.72 & 7.24 & 7.49 & 7.62 & 7.66 & 8.02 & 8.04 & 8.03 & 8.07 & 8.06 & 8.00 \\
\hline Yozgat & 5.73 & 6.22 & 6.52 & 6.84 & 6.91 & 7.11 & 7.22 & 7.37 & 7.48 & 7.61 & 7.72 \\
\hline Zonguldak & 6.55 & 7.18 & 7.39 & 7.48 & 7.54 & 7.73 & 7.84 & 7.93 & 8.00 & 8.11 & 8.18 \\
\hline
\end{tabular}


Tablo 6. İl ve Yıl Kırılımında Genel Olarak Liseye Kadar Olan Eğitimi Dikkate Alan Ortalama Okullaşma Yılı (Mean Years of Schooling-High School)

\begin{tabular}{|c|c|c|c|c|c|c|c|c|c|c|c|}
\hline & 2009 & 2010 & 2011 & 2012 & 2013 & 2014 & 2015 & 2016 & 2017 & 2018 & 2019 \\
\hline Türkiye & 5.19 & 5.71 & 6.05 & 6.17 & 6.25 & 6.47 & 6.62 & 6.78 & 6.90 & 7.07 & 7.28 \\
\hline Adana & 5.82 & 6.35 & 6.62 & 6.62 & 6.79 & 6.98 & 7.13 & 7.28 & 7.38 & 7.52 & 7.66 \\
\hline Adiyaman & 4.72 & 5.24 & 5.57 & 5.89 & 6.00 & 6.18 & 6.35 & 6.57 & 6.70 & 6.91 & 7.22 \\
\hline Afyonkarahisar & 5.37 & 5.82 & 6.18 & 6.26 & 6.34 & 6.49 & 6.62 & 6.76 & 6.86 & 7.00 & 7.11 \\
\hline Ağr1 & 3.00 & 3.73 & 4.30 & 4.38 & 4.41 & 4.67 & 4.84 & 5.04 & 5.18 & 5.43 & 5.88 \\
\hline Aksaray & 4.92 & 5.41 & 5.85 & 5.96 & 6.03 & 6.25 & 6.34 & 6.49 & 6.58 & 6.71 & 6.84 \\
\hline Amasya & 5.46 & 5.92 & 6.17 & 6.30 & 6.40 & 6.61 & 6.75 & 6.94 & 7.05 & 7.21 & 7.36 \\
\hline Ankara & 7.12 & 7.46 & 7.64 & 7.74 & 7.80 & 8.04 & 8.17 & 8.26 & 8.33 & 8.41 & 8.45 \\
\hline Antalya & 6.09 & 6.52 & 6.76 & 6.88 & 6.91 & 7.19 & 7.36 & 7.49 & 7.61 & 7.69 & 7.71 \\
\hline Arda & 4.52 & 5.04 & 5.49 & 5.59 & 5.64 & 5.85 & 6.02 & 6.28 & 6.40 & 6.63 & 6.85 \\
\hline Artvin & 5.65 & 6.14 & 6.45 & 6.60 & 6.72 & 6.94 & 7.13 & 7.30 & 7.41 & 7.60 & 7.72 \\
\hline Aydın & 5.47 & 5.93 & 6.31 & 6.42 & 6.48 & 6.72 & 6.85 & 7.05 & 7.17 & 7.33 & 7.44 \\
\hline Balık & 5.70 & 6.07 & 6.42 & 6.52 & 6.60 & 6.83 & 6.96 & 7.11 & 7.22 & 7.38 & 7.48 \\
\hline Bartın & 4.85 & 5.42 & 5.69 & 5.79 & 5.90 & 6.10 & 6.27 & 6.44 & 6.56 & 6.75 & 6.88 \\
\hline Batman & 3.96 & 4.98 & 5.37 & 5.48 & 5.57 & 5.77 & 5.97 & 6.18 & 6.36 & 6.61 & 7.23 \\
\hline Bay & 4.89 & 5.57 & 5.89 & 6.03 & 6.14 & 6.28 & 6.43 & 6.67 & 6.78 & 6.88 & 7.21 \\
\hline Bilecik & 6.12 & 6.59 & 6.88 & 6.97 & 7.03 & 7.21 & 7.32 & 7.46 & 7.58 & 7.71 & 7.82 \\
\hline Bingöl & 4.02 & 4.71 & 5.21 & 5.34 & 5.45 & 5.71 & 5.94 & 6.20 & 6.38 & 6.66 & 7.48 \\
\hline Bitlis & 3.97 & 4.69 & 5.14 & 5.26 & 5.33 & 5.55 & 5.73 & 6.00 & 6.14 & 6.44 & 7.01 \\
\hline Bolu & 5.76 & 6.19 & 6.45 & 6.57 & 6.65 & 6.83 & 6.97 & 7.13 & 7.25 & 7.35 & 7.42 \\
\hline Burdur & 5.57 & 5.98 & 6.19 & 6.29 & 6.38 & 6.55 & 6.70 & 6.86 & 6.99 & 7.16 & 7.28 \\
\hline Bursa & 6.14 & 6.60 & 6.87 & 6.97 & 7.04 & 7.31 & 7.44 & 7.56 & 7.69 & 7.78 & 7.86 \\
\hline Çanakka & 5.73 & 6.09 & 6.43 & 6.54 & 6.64 & 6.85 & 6.99 & 7.13 & 7.27 & 7.42 & 7.54 \\
\hline Çankırı & 5.32 & 5.73 & 6.07 & 6.20 & 6.26 & 6.40 & 6.53 & 6.65 & 6.79 & 6.98 & 7.03 \\
\hline Çorum & 4.74 & 5.24 & 5.56 & 5.69 & 5.77 & 5.97 & 6.13 & 6.30 & 6.41 & 6.56 & 6.71 \\
\hline Denizli & 5.64 & 6.12 & 6.51 & 6.63 & 6.72 & 6.92 & 7.06 & 7.22 & 7.34 & 7.49 & 7.59 \\
\hline Diyarl & 3.88 & 4.58 & 4.93 & 5.09 & 5.18 & 5.42 & 5.59 & 5.81 & 5.98 & 6.25 & 6.77 \\
\hline Düzce & 5.41 & 6.00 & 6.30 & 6.41 & 6.52 & 6.75 & 6.91 & 7.08 & 7.22 & 7.35 & 7.48 \\
\hline Edirne & 5.87 & 6.23 & 6.47 & 6.57 & 6.66 & 6.85 & 6.96 & 7.12 & 7.24 & 7.38 & 7.49 \\
\hline Elazığ & 5.14 & 5.66 & 5.97 & 6.08 & 6.18 & 6.42 & 6.60 & 6.76 & 6.89 & 7.07 & 7.36 \\
\hline Erzincan & 5.37 & 5.87 & 6.12 & 6.25 & 6.37 & 6.53 & 6.76 & 6.88 & 7.02 & 7.14 & 7.43 \\
\hline Erzurum & 4.93 & 5.45 & 5.76 & 5.91 & 5.99 & 6.20 & 6.39 & 6.56 & 6.71 & 6.87 & 7.04 \\
\hline Eskişehir & 6.58 & 6.99 & 7.22 & 7.33 & 7.41 & 7.65 & 7.77 & 7.88 & 7.96 & 8.05 & 8.12 \\
\hline Gaziantep & 4.83 & 5.53 & 5.84 & 6.15 & 6.21 & 6.41 & 6.54 & 6.72 & 6.85 & 7.01 & 7.16 \\
\hline Giresun & 4.90 & 5.36 & 5.60 & 5.71 & 5.81 & 6.04 & 6.23 & 6.43 & 6.53 & 6.69 & 6.86 \\
\hline Gümüşha & 5.08 & 5.53 & 5.86 & 5.98 & 6.10 & 6.32 & 6.48 & 6.45 & 6.35 & 6.96 & 6.80 \\
\hline Hakkâri & 3.90 & 4.55 & 5.28 & 5.42 & 5.50 & 5.76 & 5.98 & 6.06 & 6.28 & 6.77 & 7.79 \\
\hline Hatay & 5.18 & 5.67 & 5.98 & 6.08 & 6.16 & 6.40 & 6.56 & 6.76 & 6.86 & 7.00 & 7.14 \\
\hline Iğdır & 3.94 & 4.69 & 5.21 & 5.32 & 5.39 & 5.60 & 5.77 & 5.98 & 6.12 & 6.38 & 6.63 \\
\hline Isparta & 6.00 & 6.44 & 6.61 & 6.73 & 6.81 & 7.03 & 7.19 & 7.36 & 7.47 & 7.59 & 7.68 \\
\hline İstanbul & 6.36 & 6.82 & 7.04 & 7.13 & 7.19 & 7.53 & 7.69 & 7.78 & 7.83 & 7.92 & 7.91 \\
\hline İzmir & 6.37 & 6.76 & 7.16 & 7.22 & 7.29 & 7.49 & 7.63 & 7.75 & 7.85 & 7.99 & 8.09 \\
\hline Kahramanmaraş & 4.94 & 5.53 & 5.82 & 5.92 & 6.02 & 6.26 & 6.44 & 6.66 & 6.78 & 6.96 & 7.12 \\
\hline
\end{tabular}




\begin{tabular}{|c|c|c|c|c|c|c|c|c|c|c|c|}
\hline Karabük & 5.60 & 6.12 & 6.35 & 6.48 & 6.57 & 6.73 & 6.88 & 7.04 & 7.15 & 7.26 & 7.38 \\
\hline Karaman & 5.52 & 6.02 & 6.29 & 6.42 & 6.50 & 6.69 & 6.84 & 7.00 & 7.09 & 7.24 & 7.34 \\
\hline Kars & 4.41 & 4.99 & 5.46 & 5.53 & 5.61 & 5.86 & 6.02 & 6.26 & 6.39 & 6.57 & 6.78 \\
\hline Kastamonu & 4.84 & 5.24 & 5.50 & 5.61 & 5.73 & 5.91 & 6.00 & 6.20 & 6.33 & 6.48 & 6.61 \\
\hline Kayseri & 5.76 & 6.28 & 6.53 & 6.80 & 6.88 & 7.06 & 7.21 & 7.34 & 7.46 & 7.58 & 7.69 \\
\hline Kırıkkale & 5.93 & 6.46 & 6.90 & 6.99 & 7.05 & 7.20 & 7.31 & 7.42 & 7.53 & 7.64 & 7.74 \\
\hline Kirklareli & 6.18 & 6.62 & 6.88 & 6.97 & 7.05 & 7.24 & 7.36 & 7.50 & 7.61 & 7.73 & 7.84 \\
\hline Kurşehir & 5.60 & 6.07 & 6.48 & 6.56 & 6.63 & 6.80 & 6.93 & 7.07 & 7.10 & 7.18 & 7.27 \\
\hline Kilis & 4.70 & 5.47 & 5.93 & 6.08 & 6.10 & 6.34 & 6.46 & 6.71 & 6.81 & 7.09 & 7.47 \\
\hline Kocaeli & 6.22 & 6.79 & 7.10 & 7.20 & 7.28 & 7.55 & 7.71 & 7.85 & 7.95 & 8.10 & 8.19 \\
\hline Konya & 5.58 & 5.99 & 6.23 & 6.36 & 6.43 & 6.63 & 6.78 & 6.93 & 7.05 & 7.18 & 7.29 \\
\hline Kütahya & 5.46 & 5.92 & 6.20 & 6.31 & 6.42 & 6.54 & 6.68 & 6.83 & 6.94 & 7.09 & 7.22 \\
\hline Malatya & 5.44 & 5.98 & 6.36 & 6.46 & 6.55 & 6.77 & 6.94 & 7.11 & 7.22 & 7.36 & 7.50 \\
\hline Manisa & 5.33 & 5.80 & 6.12 & 6.22 & 6.32 & 6.50 & 6.63 & 6.80 & 6.91 & 7.08 & 7.22 \\
\hline Mardin & 3.77 & 4.34 & 4.81 & 4.92 & 5.01 & 5.24 & 5.44 & 5.65 & 5.81 & 6.04 & 6.46 \\
\hline Mersin & 5.77 & 6.21 & 6.54 & 6.63 & 6.68 & 6.89 & 7.03 & 7.16 & 7.26 & 7.40 & 7.50 \\
\hline Muğla & 5.97 & 6.37 & 6.68 & 6.76 & 6.78 & 7.13 & 7.27 & 7.42 & 7.56 & 7.72 & 7.81 \\
\hline Muş & 3.25 & 4.09 & 4.57 & 4.69 & 4.76 & 4.98 & 5.16 & 5.40 & 5.56 & 5.79 & 6.58 \\
\hline Nevşehir & 5.53 & 6.03 & 6.39 & 6.48 & 6.57 & 6.72 & 6.87 & 7.00 & 7.08 & 7.18 & 7.27 \\
\hline Niğde & 5.25 & 5.78 & 6.19 & 6.27 & 6.36 & 6.54 & 6.67 & 6.84 & 6.95 & 7.09 & 7.21 \\
\hline Ordu & 4.83 & 5.30 & 5.51 & 5.64 & 5.73 & 5.96 & 6.13 & 6.32 & 6.44 & 6.62 & 6.76 \\
\hline Osmaniye & 5.53 & 6.08 & 6.37 & 6.48 & 6.58 & 6.82 & 6.99 & 7.21 & 7.34 & 7.50 & 7.64 \\
\hline Rize & 5.40 & 5.99 & 6.30 & 6.40 & 6.50 & 6.72 & 6.94 & 7.14 & 7.28 & 7.44 & 7.61 \\
\hline Sakarya & 5.70 & 6.21 & 6.53 & 6.63 & 6.72 & 6.95 & 7.08 & 7.21 & 7.37 & 7.51 & 7.63 \\
\hline Samsun & 5.23 & 5.69 & 5.97 & 6.12 & 6.21 & 6.44 & 6.61 & 6.78 & 6.89 & 7.04 & 7.17 \\
\hline Siirt & 3.72 & 4.51 & 5.01 & 5.09 & 5.18 & 5.47 & 5.56 & 5.77 & 5.93 & 6.20 & 6.70 \\
\hline Sinop & 4.90 & 5.35 & 5.66 & 5.77 & 5.84 & 6.02 & 6.18 & 6.36 & 6.48 & 6.62 & 6.74 \\
\hline Sivas & 5.23 & 5.71 & 5.92 & 6.18 & 6.26 & 6.39 & 6.56 & 6.74 & 6.88 & 6.97 & 7.15 \\
\hline Şanlıurfa & 3.16 & 3.95 & 4.34 & 4.43 & 4.49 & 4.76 & 4.94 & 5.14 & 5.30 & 5.51 & 6.02 \\
\hline Şırnak & 3.12 & 3.91 & 4.47 & 4.56 & 4.65 & 4.92 & 5.06 & 5.21 & 5.56 & 5.93 & 6.82 \\
\hline Tekirdağ & 6.22 & 6.69 & 6.96 & 7.05 & 7.13 & 7.38 & 7.50 & 7.64 & 7.73 & 7.87 & 7.97 \\
\hline Tokat & 4.96 & 5.44 & 5.69 & 5.85 & 5.93 & 6.12 & 6.28 & 6.46 & 6.59 & 6.75 & 6.90 \\
\hline Trabzon & 5.65 & 6.12 & 6.37 & 6.49 & 6.58 & 6.79 & 7.01 & 7.18 & 7.30 & 7.43 & 7.55 \\
\hline Tunceli & 5.43 & 5.82 & 6.34 & 6.44 & 6.56 & 6.86 & 7.03 & 7.17 & 7.30 & 7.48 & 7.67 \\
\hline Uşak & 5.54 & 6.03 & 6.37 & 6.47 & 6.55 & 6.69 & 6.81 & 6.92 & 7.01 & 7.15 & 7.27 \\
\hline Van & 3.62 & 4.31 & 4.63 & 4.78 & 4.89 & 5.15 & 5.34 & 5.55 & 5.73 & 5.99 & 6.36 \\
\hline Yalova & 6.13 & 6.59 & 6.84 & 6.96 & 7.00 & 7.34 & 7.40 & 7.41 & 7.46 & 7.48 & 7.44 \\
\hline Yozgat & 4.85 & 5.28 & 5.56 & 5.85 & 5.92 & 6.10 & 6.22 & 6.38 & 6.49 & 6.62 & 6.77 \\
\hline Zonguldak & 5.55 & 6.03 & 6.25 & 6.35 & 6.42 & 6.61 & 6.74 & 6.87 & 6.95 & 7.10 & 7.19 \\
\hline
\end{tabular}


Tablo 7. İl ve Yil Kırılımında Kadınlar İçin Beklenen Okullaşma Y1lı (Expected Years of Schooling-Women)

\begin{tabular}{|c|c|c|c|c|c|c|c|c|c|c|c|}
\hline & $\begin{array}{c}2009- \\
10 \\
\end{array}$ & $\begin{array}{c}2010- \\
11 \\
\end{array}$ & $\begin{array}{c}2011- \\
12 \\
\end{array}$ & $\begin{array}{c}2012- \\
13 \\
\end{array}$ & $\begin{array}{c}2013- \\
14 \\
\end{array}$ & $\begin{array}{c}2014- \\
15 \\
\end{array}$ & $\begin{array}{c}2015- \\
16 \\
\end{array}$ & $\begin{array}{c}2016- \\
17 \\
\end{array}$ & $\begin{array}{c}2017- \\
18 \\
\end{array}$ & $\begin{array}{c}2018- \\
19 \\
\end{array}$ & $\begin{array}{c}2019- \\
20\end{array}$ \\
\hline Türkiye & 10.69 & 10.84 & 11.18 & 10.98 & 11.21 & 11.33 & 11.34 & 11.35 & 11.45 & 11.46 & 11.68 \\
\hline Adana & 10.75 & 10.82 & 11.17 & 10.98 & 11.13 & 11.29 & 11.22 & 11.30 & 11.37 & 11.38 & 11.58 \\
\hline Adiyaman & 10.24 & 10.44 & 10.89 & 10.75 & 11.08 & 11.30 & 11.38 & 11.40 & 11.51 & 11.48 & 11.68 \\
\hline $\begin{array}{l}\text { Afyonkarah } \\
\text { isar }\end{array}$ & 10.44 & 10.62 & 11.11 & 10.90 & 11.15 & 11.31 & 11.37 & 11.36 & 11.42 & 11.35 & 11.64 \\
\hline Ağr1 & 8.84 & 8.98 & 9.33 & 8.73 & 9.21 & 9.65 & 9.67 & 9.81 & 10.13 & 10.35 & 10.48 \\
\hline Aksaray & 10.23 & 10.44 & 10.82 & 10.58 & 10.94 & 10.97 & 11.06 & 11.26 & 11.26 & 11.23 & 11.45 \\
\hline Amasya & 11.75 & 11.95 & 12.14 & 11.93 & 12.13 & 12.18 & 12.17 & 12.13 & 12.17 & 12.08 & 12.36 \\
\hline Ankara & 11.66 & 11.65 & 11.94 & 11.82 & 11.94 & 11.90 & 11.81 & 11.83 & 11.83 & 11.89 & 12.11 \\
\hline Antalya & 11.10 & 11.21 & 11.62 & 11.55 & 11.69 & 11.63 & 11.65 & 11.71 & 11.75 & 11.69 & 12.02 \\
\hline Ardahan & 10.35 & 10.58 & 11.20 & 11.08 & 11.18 & 11.39 & 11.57 & 11.54 & 11.70 & 11.71 & 11.68 \\
\hline Artvin & 11.62 & 11.66 & 12.11 & 12.03 & 12.10 & 12.13 & 12.08 & 12.14 & 12.00 & 11.82 & 12.21 \\
\hline Aydın & 11.15 & 11.30 & 11.67 & 11.54 & 11.63 & 11.70 & 11.69 & 11.67 & 11.64 & 11.61 & 11.91 \\
\hline Balıkesir & 11.33 & 11.40 & 11.74 & 11.63 & 11.73 & 11.74 & 11.76 & 11.77 & 11.87 & 11.78 & 12.09 \\
\hline Bartın & 10.97 & 11.22 & 11.70 & 11.54 & 11.83 & 11.98 & 12.12 & 12.06 & 12.11 & 11.89 & 12.29 \\
\hline Batman & 9.62 & 9.79 & 10.21 & 9.92 & 10.27 & 10.64 & 10.75 & 10.86 & 11.05 & 11.17 & 11.22 \\
\hline Bayburt & 10.46 & 10.53 & 11.12 & 11.07 & 11.53 & 11.08 & 11.11 & 9.88 & 11.57 & 11.35 & 11.47 \\
\hline Bilecik & 11.90 & 11.96 & 12.28 & 12.12 & 12.13 & 12.07 & 11.93 & 12.04 & 11.99 & 11.84 & 12.09 \\
\hline Bingöl & 9.28 & 9.59 & 10.12 & 9.83 & 10.33 & 10.70 & 10.85 & 10.82 & 11.12 & 11.14 & 11.34 \\
\hline Bitlis & 8.83 & 9.03 & 9.64 & 9.13 & 9.74 & 10.06 & 10.02 & 10.06 & 10.17 & 10.38 & 10.55 \\
\hline Bolu & 11.68 & 11.67 & 11.99 & 11.89 & 11.99 & 11.89 & 11.78 & 11.88 & 11.89 & 11.81 & 12.10 \\
\hline Burdur & 11.43 & 11.44 & 11.84 & 11.86 & 11.85 & 11.57 & 11.66 & 11.76 & 11.81 & 11.74 & 12.11 \\
\hline Bursa & 11.18 & 11.21 & 11.55 & 11.46 & 11.60 & 11.67 & 11.67 & 11.63 & 11.67 & 11.64 & 11.88 \\
\hline Çanakkale & 11.60 & 11.72 & 12.01 & 11.91 & 11.82 & 11.72 & 11.70 & 11.63 & 11.71 & 11.69 & 12.03 \\
\hline Çankırı & 10.10 & 10.38 & 11.08 & 10.44 & 10.43 & 10.93 & 10.98 & 11.11 & 11.12 & 9.71 & 11.22 \\
\hline Çorum & 10.57 & 10.84 & 11.20 & 11.20 & 11.41 & 11.51 & 11.44 & 11.59 & 11.68 & 11.57 & 11.93 \\
\hline Denizli & 11.22 & 11.37 & 11.70 & 11.64 & 11.72 & 11.70 & 11.68 & 11.74 & 11.79 & 11.72 & 12.05 \\
\hline Diyarbakır & 9.68 & 9.84 & 10.26 & 9.89 & 10.27 & 10.51 & 10.52 & 10.60 & 10.96 & 11.05 & 11.18 \\
\hline Düzce & 11.15 & 11.18 & 11.55 & 11.36 & 11.50 & 11.70 & 11.63 & 11.66 & 11.74 & 11.75 & 12.02 \\
\hline Edirne & 11.54 & 11.67 & 12.02 & 11.85 & 11.89 & 11.77 & 11.72 & 11.66 & 11.76 & 11.72 & 11.94 \\
\hline Elazı̆̆ & 10.89 & 11.13 & 11.67 & 11.18 & 11.32 & 11.54 & 11.64 & 11.56 & 11.66 & 11.50 & 11.84 \\
\hline Erzincan & 11.02 & 11.09 & 11.61 & 11.38 & 11.63 & 11.66 & 11.60 & 11.70 & 11.81 & 11.85 & 12.14 \\
\hline Erzurum & 9.71 & 9.89 & 10.29 & 9.96 & 10.49 & 10.72 & 10.77 & 10.87 & 10.96 & 10.99 & 11.19 \\
\hline Eskişehir & 11.75 & 11.80 & 12.08 & 11.89 & 12.00 & 11.96 & 11.88 & 11.95 & 12.05 & 11.98 & 12.24 \\
\hline Gaziantep & 10.12 & 10.22 & 10.58 & 10.44 & 10.70 & 10.94 & 11.00 & 11.09 & 11.22 & 11.28 & 11.35 \\
\hline Giresun & 11.24 & 11.43 & 11.90 & 11.79 & 11.88 & 11.75 & 11.81 & 11.33 & 11.70 & 11.52 & 12.01 \\
\hline $\begin{array}{l}\text { Gümüşhan } \\
\text { e }\end{array}$ & 10.30 & 10.55 & 10.97 & 10.16 & 10.21 & 9.58 & 8.92 & 7.51 & 7.65 & 8.78 & 8.59 \\
\hline Hakkâri & 8.94 & 9.27 & 9.87 & 9.38 & 9.73 & 9.87 & 9.93 & 9.98 & 10.38 & 10.58 & 10.61 \\
\hline Hatay & 10.64 & 11.06 & 11.39 & 11.00 & 11.23 & 11.46 & 11.47 & 11.43 & 11.55 & 11.52 & 11.75 \\
\hline Iğdır & 10.03 & 10.24 & 10.67 & 10.36 & 10.68 & 10.93 & 11.10 & 11.21 & 11.41 & 11.52 & 11.47 \\
\hline Isparta & 11.77 & 11.83 & 12.31 & 12.11 & 12.22 & 11.99 & 12.02 & 12.06 & 12.21 & 12.07 & 12.30 \\
\hline İstanbul & 11.01 & 11.03 & 11.28 & 11.17 & 11.43 & 11.49 & 11.50 & 11.52 & 11.55 & 11.63 & 11.88 \\
\hline
\end{tabular}


PJESS'2021 / 8(2)

\begin{tabular}{|c|c|c|c|c|c|c|c|c|c|c|c|}
\hline İzmir & 11.35 & 11.54 & 11.89 & 11.57 & 11.66 & 11.71 & 11.72 & 11.63 & 11.73 & 11.70 & 11.97 \\
\hline $\begin{array}{l}\text { Kahraman } \\
\text { maraş }\end{array}$ & 10.15 & 10.28 & 10.79 & 10.56 & 10.81 & 10.99 & 11.02 & 11.11 & 11.21 & 11.22 & 11.50 \\
\hline Karabük & 11.77 & 11.87 & 12.21 & 12.06 & 12.06 & 12.14 & 11.92 & 12.03 & 12.14 & 12.01 & 12.33 \\
\hline Karaman & 10.98 & 11.20 & 11.59 & 11.56 & 11.85 & 11.83 & 11.93 & 11.91 & 11.95 & 11.84 & 12.19 \\
\hline Kars & 9.48 & 9.76 & 10.17 & 9.99 & 10.30 & 10.65 & 10.73 & 11.55 & 10.91 & 10.98 & 11.18 \\
\hline Kastamonu & 10.82 & 11.00 & 11.59 & 11.32 & 11.63 & 11.78 & 11.69 & 11.70 & 11.85 & 11.74 & 12.05 \\
\hline Kayseri & 11.08 & 11.12 & 11.46 & 11.34 & 11.57 & 11.66 & 11.70 & 11.93 & 11.81 & 11.82 & 12.02 \\
\hline Kırıkkale & 11.24 & 11.53 & 11.97 & 11.63 & 11.66 & 11.89 & 11.88 & 11.86 & 11.95 & 11.68 & 12.06 \\
\hline Kirklareli & 11.70 & 11.71 & 11.99 & 11.91 & 11.91 & 11.78 & 11.76 & 11.75 & 11.70 & 11.65 & 11.92 \\
\hline Kırşehir & 11.36 & 11.44 & 11.88 & 11.74 & 11.69 & 11.72 & 11.68 & 11.72 & 11.86 & 11.69 & 11.99 \\
\hline Kilis & 10.54 & 10.70 & 11.11 & 10.97 & 11.13 & 11.32 & 11.37 & 10.37 & 11.26 & 11.16 & 11.51 \\
\hline Kocaeli & 11.41 & 11.41 & 11.77 & 11.67 & 11.77 & 11.83 & 11.84 & 11.98 & 12.00 & 12.12 & 12.29 \\
\hline Konya & 10.48 & 10.71 & 11.27 & 10.97 & 11.31 & 11.43 & 11.51 & 11.63 & 11.50 & 11.42 & 11.68 \\
\hline Kütahya & 11.10 & 11.44 & 11.99 & 11.84 & 12.02 & 12.00 & 11.92 & 11.99 & 12.13 & 11.95 & 12.21 \\
\hline Malatya & 11.04 & 11.20 & 11.66 & 11.43 & 11.67 & 11.72 & 11.76 & 11.79 & 11.97 & 11.96 & 12.13 \\
\hline Manisa & 10.93 & 11.13 & 11.52 & 11.45 & 11.61 & 11.68 & 11.69 & 11.61 & 11.67 & 11.60 & 11.90 \\
\hline Mardin & 9.24 & 9.42 & 9.86 & 9.63 & 10.00 & 10.38 & 10.47 & 10.45 & 10.68 & 10.80 & 10.89 \\
\hline Mersin & 10.97 & 11.19 & 11.74 & 11.33 & 11.45 & 11.58 & 11.58 & 11.61 & 11.69 & 11.69 & 11.92 \\
\hline Muğla & 11.32 & 11.34 & 11.65 & 11.59 & 11.71 & 11.66 & 11.65 & 11.69 & 11.73 & 11.67 & 11.95 \\
\hline Muş & 8.76 & 9.49 & 9.74 & 8.94 & 9.19 & 9.63 & 9.52 & 9.64 & 9.68 & 9.89 & 10.03 \\
\hline Nevşehir & 11.06 & 11.21 & 11.62 & 11.33 & 11.50 & 11.63 & 11.75 & 11.67 & 11.76 & 11.76 & 11.96 \\
\hline Niğde & 10.39 & 10.57 & 11.13 & 10.98 & 11.14 & 11.40 & 11.44 & 11.46 & 11.47 & 11.35 & 11.72 \\
\hline Ordu & 10.46 & 10.76 & 11.27 & 10.78 & 11.29 & 11.61 & 11.68 & 11.44 & 11.88 & 11.58 & 12.13 \\
\hline Osmaniye & 10.79 & 10.93 & 11.19 & 11.14 & 11.27 & 11.30 & 11.19 & 11.27 & 11.35 & 11.39 & 11.62 \\
\hline Rize & 11.69 & 11.80 & 12.22 & 12.00 & 12.23 & 12.25 & 12.17 & 12.15 & 12.21 & 11.86 & 12.29 \\
\hline Sakarya & 11.12 & 11.23 & 11.61 & 11.38 & 11.61 & 11.71 & 11.65 & 11.70 & 11.74 & 11.74 & 11.95 \\
\hline Samsun & 11.04 & 11.15 & 11.56 & 11.44 & 11.60 & 11.80 & 11.80 & 11.79 & 11.86 & 11.84 & 12.10 \\
\hline Siirt & 9.13 & 9.39 & 9.92 & 9.46 & 9.82 & 10.31 & 10.26 & 10.38 & 10.51 & 10.47 & 10.62 \\
\hline Sinop & 10.89 & 11.26 & 11.65 & 11.51 & 11.50 & 11.69 & 11.75 & 11.83 & 11.90 & 11.35 & 11.67 \\
\hline Sivas & 10.69 & 10.84 & 11.25 & 11.11 & 11.34 & 11.53 & 11.55 & 11.68 & 11.81 & 11.61 & 11.91 \\
\hline Şanlıurfa & 9.20 & 9.51 & 9.78 & 9.22 & 9.64 & 9.98 & 10.06 & 9.99 & 10.18 & 10.19 & 10.22 \\
\hline Şırnak & 8.92 & 9.13 & 9.61 & 9.26 & 9.91 & 10.28 & 10.12 & 10.07 & 10.53 & 10.57 & 10.61 \\
\hline Tekirdağ & 11.28 & 11.37 & 11.77 & 11.47 & 11.58 & 11.50 & 11.50 & 11.58 & 11.54 & 11.50 & 11.82 \\
\hline Tokat & 10.14 & 10.42 & 10.72 & 10.46 & 11.06 & 11.21 & 11.18 & 11.10 & 11.15 & 11.10 & 11.14 \\
\hline Trabzon & 11.38 & 11.45 & 11.96 & 11.79 & 12.02 & 12.07 & 12.10 & 12.07 & 12.08 & 11.88 & 12.26 \\
\hline Tunceli & 11.33 & 11.40 & 11.72 & 11.58 & 11.58 & 11.57 & 11.43 & 11.52 & 11.48 & 11.14 & 11.65 \\
\hline Uşak & 11.49 & 11.51 & 11.99 & 11.81 & 11.88 & 11.94 & 11.89 & 11.85 & 11.90 & 11.88 & 12.14 \\
\hline Van & 8.70 & 9.19 & 8.41 & 9.06 & 9.49 & 9.85 & 10.02 & 10.22 & 10.52 & 10.74 & 10.88 \\
\hline Yalova & 11.44 & 11.51 & 11.96 & 11.57 & 11.67 & 11.61 & 11.58 & 11.73 & 11.64 & 11.63 & 11.94 \\
\hline Yozgat & 9.79 & 10.03 & 10.69 & 10.52 & 10.81 & 10.77 & 10.89 & 10.89 & 10.96 & 10.89 & 11.21 \\
\hline Zonguldak & 11.06 & 11.22 & 11.57 & 11.59 & 11.77 & 11.86 & 11.91 & 11.83 & 11.87 & 11.82 & 12.09 \\
\hline
\end{tabular}


Tablo 8. İl ve Yıl Kırılımında Erkekler İçin Beklenen Okullaşma Yılı (Expected Years of Schooling-Men)

\begin{tabular}{|c|c|c|c|c|c|c|c|c|c|c|c|}
\hline & $\begin{array}{c}2009- \\
10\end{array}$ & $\begin{array}{c}2010- \\
11\end{array}$ & $\begin{array}{c}2011- \\
12\end{array}$ & $\begin{array}{c}2012- \\
13\end{array}$ & $\begin{array}{c}2013- \\
14\end{array}$ & $\begin{array}{c}2014- \\
15\end{array}$ & $\begin{array}{c}2015- \\
16\end{array}$ & $\begin{array}{l}2016- \\
17\end{array}$ & $\begin{array}{l}2017- \\
18\end{array}$ & $\begin{array}{c}2018- \\
19\end{array}$ & $\begin{array}{c}2019- \\
20\end{array}$ \\
\hline Türkiye & 10.97 & 11.05 & 11.30 & 11.08 & 11.30 & 11.35 & 11.30 & 11.38 & 11.46 & 11.46 & 11.70 \\
\hline Adana & 10.97 & 10.99 & 11.26 & 11.05 & 11.20 & 11.38 & 11.21 & 10.75 & 11.37 & 11.39 & 11.59 \\
\hline Adiyaman & 10.59 & 10.71 & 11.08 & 10.88 & 11.15 & 11.28 & 11.26 & 11.33 & 11.45 & 11.41 & 11.65 \\
\hline $\begin{array}{l}\text { Afyonkarah } \\
\text { isar }\end{array}$ & 10.84 & 11.00 & 11.33 & 11.04 & 11.21 & 11.42 & 11.22 & 11.34 & 11.38 & 11.35 & 11.63 \\
\hline Ăgrı & 9.27 & 9.35 & 9.67 & 9.20 & 9.60 & 9.99 & 9.90 & 9.92 & 10.15 & 10.29 & 10.34 \\
\hline Aksaray & 10.48 & 10.60 & 10.91 & 10.58 & 10.90 & 10.90 & 10.97 & 11.52 & 11.55 & 11.47 & 11.43 \\
\hline Amasya & 12.05 & 12.20 & 12.35 & 12.13 & 12.28 & 12.23 & 12.14 & 12.19 & 12.21 & 12.03 & 12.39 \\
\hline Ankara & 11.67 & 11.63 & 11.86 & 11.73 & 11.89 & 11.82 & 11.63 & 11.97 & 11.75 & 11.82 & 12.08 \\
\hline Antalya & 11.11 & 11.22 & 11.53 & 11.48 & 11.57 & 11.46 & 11.44 & 11.60 & 11.62 & 11.58 & 11.97 \\
\hline Ardahan & 10.49 & 10.66 & 11.17 & 11.06 & 11.24 & 11.34 & 11.35 & 11.40 & 11.42 & 11.41 & 11.50 \\
\hline Artvin & 11.92 & 11.88 & 12.27 & 12.08 & 12.11 & 12.10 & 11.97 & 12.15 & 12.10 & 11.93 & 12.30 \\
\hline Aydın & 11.16 & 11.30 & 11.55 & 11.43 & 11.52 & 11.68 & 11.52 & 11.66 & 11.64 & 11.64 & 11.96 \\
\hline Balıkesir & 11.42 & 11.44 & 11.71 & 11.63 & 11.69 & 11.65 & 11.64 & 11.68 & 11.76 & 11.79 & 12.05 \\
\hline Bartın & 11.40 & 11.55 & 11.99 & 11.77 & 11.91 & 12.03 & 12.07 & 11.92 & 12.05 & 11.84 & 12.26 \\
\hline Batman & 10.20 & 10.28 & 10.64 & 10.24 & 10.60 & 10.80 & 10.85 & 10.97 & 11.17 & 11.22 & 11.26 \\
\hline Bayburt & 11.28 & 11.37 & 11.80 & 11.68 & 11.81 & 11.17 & 11.11 & 10.03 & 11.54 & 11.35 & 11.45 \\
\hline Bilecik & 12.04 & 12.21 & 12.32 & 12.14 & 12.11 & 11.91 & 11.79 & 12.13 & 11.96 & 11.66 & 11.97 \\
\hline Bingöl & 10.04 & 10.23 & 10.59 & 10.26 & 10.78 & 11.04 & 11.07 & 11.04 & 11.29 & 11.23 & 11.44 \\
\hline Bitlis & 9.79 & 9.81 & 10.39 & 9.90 & 10.33 & 10.61 & 10.58 & 10.68 & 10.78 & 10.88 & 10.98 \\
\hline Bolu & 12.22 & 12.17 & 12.43 & 12.34 & 12.38 & 12.20 & 12.12 & 12.08 & 12.06 & 12.06 & 12.56 \\
\hline Burdur & 11.43 & 11.55 & 11.83 & 11.87 & 11.72 & 11.44 & 11.46 & 11.65 & 11.67 & 11.63 & 11.94 \\
\hline Bursa & 11.42 & 11.38 & 11.66 & 11.53 & 11.61 & 11.63 & 11.60 & 11.64 & 11.66 & 11.63 & 11.90 \\
\hline Çanakkale & 11.84 & 11.74 & 12.11 & 12.02 & 11.99 & 11.80 & 11.71 & 11.61 & 11.70 & 11.67 & 12.00 \\
\hline Çankırı & 10.69 & 10.89 & 11.60 & 10.75 & 10.57 & 10.90 & 10.87 & 11.01 & 11.00 & 9.56 & 11.15 \\
\hline Çorum & 10.89 & 11.09 & 11.35 & 11.26 & 11.40 & 11.39 & 11.27 & 11.51 & 11.65 & 11.50 & 12.01 \\
\hline Denizli & 11.22 & 11.65 & 11.59 & 11.50 & 11.60 & 11.60 & 11.47 & 11.67 & 11.72 & 11.60 & 11.95 \\
\hline Diyarbakır & 10.27 & 10.30 & 10.63 & 10.22 & 10.59 & 10.70 & 10.69 & 10.80 & 11.03 & 11.11 & 11.24 \\
\hline Düzce & 11.53 & 11.46 & 11.73 & 11.52 & 11.57 & 11.64 & 11.62 & 11.66 & 11.65 & 11.67 & 11.98 \\
\hline Edirne & 11.65 & 11.76 & 12.12 & 11.82 & 12.17 & 11.88 & 11.72 & 11.65 & 11.63 & 11.53 & 11.89 \\
\hline Elazı̆̆ & 11.43 & 11.62 & 12.01 & 11.52 & 11.58 & 11.70 & 11.73 & 11.65 & 11.74 & 11.55 & 11.90 \\
\hline Erzincan & 11.72 & 11.69 & 12.06 & 11.76 & 11.90 & 11.82 & 11.68 & 11.90 & 11.92 & 11.87 & 12.22 \\
\hline Erzurum & 10.40 & 10.44 & 10.77 & 10.39 & 10.74 & 10.80 & 10.81 & 10.97 & 11.05 & 11.03 & 11.23 \\
\hline Eskişehir & 11.98 & 11.96 & 12.19 & 12.06 & 12.08 & 11.96 & 11.83 & 11.95 & 12.05 & 12.01 & 12.24 \\
\hline Gaziantep & 10.50 & 10.53 & 10.79 & 10.52 & 10.78 & 10.95 & 10.99 & 11.08 & 11.26 & 11.24 & 11.33 \\
\hline Giresun & 11.63 & 11.85 & 12.19 & 12.01 & 12.06 & 11.90 & 11.95 & 11.45 & 11.79 & 11.55 & 12.03 \\
\hline $\begin{array}{l}\text { Gümüşhan } \\
\text { e }\end{array}$ & 10.78 & 11.07 & 11.29 & 10.28 & 10.23 & 9.52 & 8.88 & 7.58 & 7.68 & 8.77 & 8.68 \\
\hline Hakkâri & 9.64 & 9.71 & 10.25 & 9.64 & 9.93 & 9.94 & 9.93 & 10.10 & 10.46 & 10.66 & 10.73 \\
\hline Hatay & 10.94 & 11.28 & 11.51 & 11.09 & 11.45 & 11.52 & 11.46 & 11.47 & 11.59 & 11.55 & 11.80 \\
\hline Iğdır & 10.31 & 10.29 & 10.61 & 10.21 & 10.50 & 10.66 & 10.79 & 10.81 & 10.98 & 10.99 & 10.99 \\
\hline Isparta & 11.71 & 11.76 & 12.22 & 12.09 & 12.10 & 11.87 & 11.85 & 11.93 & 12.12 & 11.98 & 12.22 \\
\hline İstanbul & 11.07 & 11.08 & 11.26 & 11.14 & 11.40 & 11.43 & 11.39 & 11.47 & 11.51 & 11.60 & 11.88 \\
\hline
\end{tabular}


PJESS'2021 / 8(2)

\begin{tabular}{|c|c|c|c|c|c|c|c|c|c|c|c|}
\hline İzmir & 11.29 & 11.45 & 11.75 & 11.44 & 11.58 & 11.55 & 11.56 & 11.55 & 11.64 & 11.62 & 11.92 \\
\hline $\begin{array}{l}\text { Kahraman } \\
\text { maraş }\end{array}$ & 10.58 & 10.61 & 11.01 & 10.73 & 10.91 & 10.97 & 10.94 & 11.07 & 11.23 & 11.22 & 11.53 \\
\hline Karabük & 11.98 & 12.00 & 12.35 & 12.07 & 12.05 & 12.02 & 11.92 & 12.05 & 12.19 & 12.02 & 12.32 \\
\hline Karaman & 11.05 & 11.15 & 11.48 & 11.40 & 11.67 & 11.84 & 11.67 & 11.70 & 11.79 & 11.72 & 12.06 \\
\hline Kars & 9.78 & 9.95 & 10.30 & 10.14 & 10.43 & 10.68 & 10.70 & 10.68 & 10.82 & 10.78 & 10.97 \\
\hline Kastamonu & 11.30 & 11.47 & 11.95 & 11.64 & 11.75 & 11.87 & 11.64 & 11.87 & 11.91 & 11.81 & 12.10 \\
\hline Kayseri & 11.29 & 11.30 & 11.54 & 11.36 & 11.55 & 11.57 & 11.54 & 11.64 & 11.71 & 11.74 & 11.98 \\
\hline Kirıkkale & 11.59 & 11.79 & 12.11 & 11.71 & 11.72 & 11.79 & 11.81 & 11.93 & 12.03 & 11.80 & 12.10 \\
\hline Kırklareli & 11.88 & 11.86 & 12.07 & 12.01 & 12.05 & 11.91 & 11.80 & 11.80 & 11.81 & 11.78 & 11.99 \\
\hline Kırşehir & 11.56 & 11.68 & 12.01 & 11.83 & 11.81 & 11.75 & 11.75 & 11.81 & 11.88 & 11.65 & 12.01 \\
\hline Kilis & 10.71 & 10.76 & 11.10 & 11.02 & 11.25 & 11.31 & 11.40 & 11.18 & 11.31 & 11.18 & 11.62 \\
\hline Kocaeli & 11.74 & 11.69 & 11.94 & 11.74 & 11.83 & 11.77 & 11.75 & 11.93 & 11.94 & 12.04 & 12.24 \\
\hline Konya & 10.74 & 10.90 & 11.33 & 11.00 & 11.26 & 11.34 & 11.37 & 11.57 & 11.46 & 11.43 & 11.69 \\
\hline Kütahya & 11.76 & 12.02 & 12.37 & 12.08 & 12.16 & 12.11 & 11.91 & 11.96 & 12.10 & 11.95 & 12.17 \\
\hline Malatya & 11.47 & 11.54 & 11.89 & 11.61 & 11.77 & 11.78 & 11.65 & 11.86 & 11.94 & 11.93 & 12.09 \\
\hline Manisa & 11.07 & 11.26 & 11.54 & 11.44 & 11.59 & 11.61 & 11.56 & 11.57 & 11.66 & 11.67 & 11.92 \\
\hline Mardin & 9.95 & 10.04 & 10.35 & 10.10 & 10.51 & 10.71 & 10.73 & 10.74 & 10.98 & 11.00 & 11.00 \\
\hline Mersin & 11.16 & 11.33 & 11.78 & 11.40 & 11.47 & 11.54 & 11.51 & 11.58 & 11.66 & 11.68 & 11.97 \\
\hline Muğla & 11.28 & 11.30 & 11.56 & 11.54 & 11.68 & 11.51 & 11.50 & 11.60 & 11.65 & 11.62 & 11.90 \\
\hline Muş & 9.47 & 9.87 & 10.18 & 9.48 & 9.70 & 9.99 & 9.84 & 9.98 & 10.10 & 10.27 & 10.39 \\
\hline Nevşehir & 11.13 & 11.26 & 11.54 & 11.23 & 11.40 & 11.49 & 11.61 & 11.60 & 11.68 & 11.61 & 11.95 \\
\hline Niğde & 10.57 & 10.76 & 11.23 & 11.01 & 11.13 & 11.30 & 11.27 & 11.32 & 11.26 & 11.12 & 11.52 \\
\hline Ordu & 10.74 & 10.96 & 11.41 & 10.80 & 11.23 & 11.52 & 11.52 & 11.52 & 11.76 & 11.44 & 12.05 \\
\hline Osmaniye & 11.03 & 11.13 & 11.28 & 11.16 & 11.21 & 11.13 & 11.00 & 11.23 & 11.14 & 11.22 & 11.52 \\
\hline Rize & 12.18 & 12.15 & 12.48 & 12.28 & 12.40 & 12.37 & 12.39 & 12.29 & 12.40 & 12.14 & 12.53 \\
\hline Sakarya & 11.61 & 11.60 & 11.82 & 11.54 & 11.67 & 11.66 & 11.58 & 11.70 & 11.72 & 11.73 & 11.95 \\
\hline Samsun & 11.27 & 11.32 & 11.63 & 11.50 & 11.61 & 11.74 & 11.70 & 11.74 & 11.79 & 11.75 & 12.05 \\
\hline Siirt & 10.04 & 10.10 & 10.51 & 10.01 & 10.49 & 10.77 & 10.76 & 10.92 & 10.91 & 10.88 & 11.03 \\
\hline Sinop & 11.21 & 11.50 & 11.81 & 11.65 & 11.66 & 11.64 & 11.70 & 11.80 & 11.84 & 11.26 & 11.68 \\
\hline Sivas & 10.99 & 11.10 & 11.48 & 11.28 & 11.42 & 11.74 & 11.49 & 11.67 & 11.78 & 11.61 & 11.93 \\
\hline Şanlıurfa & 10.03 & 10.13 & 10.33 & 9.90 & 10.30 & 10.53 & 10.51 & 10.55 & 10.68 & 10.66 & 10.67 \\
\hline Şırnak & 9.70 & 9.78 & 10.14 & 9.72 & 10.21 & 10.43 & 10.28 & 10.28 & 10.68 & 10.68 & 10.68 \\
\hline Tekirdağ & 11.51 & 11.60 & 11.86 & 11.52 & 11.60 & 11.50 & 11.44 & 11.58 & 11.46 & 11.45 & 11.77 \\
\hline Tokat & 10.57 & 10.78 & 10.97 & 10.64 & 11.11 & 11.18 & 11.08 & 11.25 & 11.27 & 11.15 & 11.23 \\
\hline Trabzon & 11.58 & 11.64 & 12.04 & 11.85 & 12.05 & 12.25 & 12.02 & 12.02 & 12.02 & 11.86 & 12.28 \\
\hline Tunceli & 11.37 & 11.59 & 11.61 & 11.48 & 11.52 & 11.53 & 11.48 & 11.55 & 11.55 & 11.38 & 11.69 \\
\hline Uşak & 11.42 & 11.35 & 11.69 & 11.43 & 11.56 & 11.50 & 11.47 & 11.54 & 11.68 & 11.72 & 12.03 \\
\hline Van & 9.60 & 9.84 & 8.76 & 9.51 & 9.87 & 10.12 & 10.16 & 10.33 & 10.54 & 10.72 & 10.86 \\
\hline Yalova & 11.50 & 11.55 & 12.01 & 11.64 & 11.72 & 11.71 & 11.57 & 11.83 & 11.76 & 11.66 & 11.88 \\
\hline Yozgat & 10.20 & 10.37 & 10.91 & 10.68 & 10.87 & 10.68 & 10.83 & 10.87 & 11.06 & 10.92 & 11.35 \\
\hline Zonguldak & 11.42 & 11.54 & 11.89 & 11.79 & 11.83 & 11.85 & 11.79 & 11.80 & 11.83 & 11.76 & 12.06 \\
\hline
\end{tabular}


Tablo 9. İl ve Yıl Kırılımında Genel Olarak Beklenen Okullaşma Yılı (Expected Years of Schooling)

\begin{tabular}{|c|c|c|c|c|c|c|c|c|c|c|c|}
\hline & $\begin{array}{c}2009- \\
10\end{array}$ & $\begin{array}{c}2010- \\
11\end{array}$ & $\begin{array}{c}2011- \\
12\end{array}$ & $\begin{array}{c}2012- \\
13\end{array}$ & $\begin{array}{c}2013- \\
14\end{array}$ & $\begin{array}{c}2014- \\
15\end{array}$ & $\begin{array}{c}2015- \\
16\end{array}$ & $\begin{array}{c}2016- \\
17\end{array}$ & $\begin{array}{c}2017- \\
18\end{array}$ & $\begin{array}{c}2018- \\
19 \\
\end{array}$ & $\begin{array}{c}2019- \\
20\end{array}$ \\
\hline Türkiye & 10.84 & 10.95 & 11.25 & 11.03 & 11.26 & 11.34 & 11.32 & 11.36 & 11.45 & 11.46 & 11.69 \\
\hline Adana & .86 & .91 & 11.22 & 11.02 & 1.17 & 11.33 & 1.22 & 1.33 & 1.37 & 1.39 & 1.59 \\
\hline Adıyaman & .42 & .58 & 0.99 & 0.82 & 1.11 & 1.29 & 1.32 & 1.36 & 1.48 & 1.44 & 1.66 \\
\hline isar & 10.65 & 10.81 & 11.23 & 10.97 & 11.18 & 11.37 & 11.30 & 11.35 & 11.40 & 11.35 & 11.63 \\
\hline Ă̆gr1 & 9.06 & 9.18 & 9.51 & 8.98 & 9.41 & 9.82 & 9.79 & 9.87 & 0.14 & 10.32 & 10.41 \\
\hline Aksar & 0.36 & 10.52 & 10.87 & 10.58 & 10.92 & 10.94 & 11.01 & 11.39 & 1.40 & 11.35 & 11.44 \\
\hline $\mathrm{Am}$ & 1.91 & 12.09 & 12.25 & 12.03 & 12.21 & 12.20 & 12.16 & 2.16 & 2.19 & 12.05 & 12.38 \\
\hline & 1.67 & 1.64 & 11.90 & 11.78 & 11.91 & 11.86 & 11.71 & 11.80 & 1.79 & 1.85 & 12.10 \\
\hline & 11 & .22 & 11.57 & 1.51 & 1.62 & 11.54 & 1.54 & 1.65 & 1.68 & 1.63 & 12.00 \\
\hline & 42 & .62 & 11.18 & .07 & .21 & 11.37 & 11.46 & 1.47 & 1.55 & 1.55 & 11.59 \\
\hline & 1.77 & .77 & 12.19 & 12.06 & 2.10 & 12.11 & 12.03 & 2.15 & 2.05 & 1.87 & 12.25 \\
\hline & 16 & .30 & 11.61 & .48 & 1.57 & 11.69 & 1.60 & 1.66 & 1.64 & 1.63 & 1.94 \\
\hline & 38 & 42 & 1.72 & & 1.71 & 1.70 & 1.70 & 1.72 & 1.82 & 1.79 & 2.07 \\
\hline Bar & 1.18 & 1.38 & 11.84 & 11.65 & 1.87 & 12.01 & 12.10 & 1.99 & 2.08 & 1.86 & 12.27 \\
\hline & 92 & .04 & 10.43 & 0.08 & 0.44 & 10.72 & 10.80 & 0.92 & 1.11 & 1.19 & 11.24 \\
\hline & 89 & .96 & 11.48 & 1.38 & 1.67 & 1.12 & 1.11 & 9.96 & 1.56 & 1.35 & 1.46 \\
\hline & .97 & 12.08 & 12.30 & 12.13 & 12.12 & 11.99 & 11.86 & 12.09 & 1.98 & 11.75 & 12.03 \\
\hline & 66 & & 10.36 & 0.05 & 10.56 & 10.87 & 0.96 & 0.93 & 20 & 1.19 & 1.39 \\
\hline & & & .03 & & .05 & 0.34 & & .38 & & & 0.77 \\
\hline Bolu & 1.96 & 1.93 & 12.22 & 12.12 & 2.18 & 12.05 & 11.95 & 2.11 & 2.07 & 2.06 & 12.34 \\
\hline & 43 & & 1.84 & & 1.78 & 11.50 & & .70 & & & 12.02 \\
\hline & & & & & & & & 1.63 & & & 11.89 \\
\hline & .72 & .73 & 12.06 & 11.97 & 1.91 & 11.76 & 11.70 & 11.62 & 1.71 & 11.68 & 12.01 \\
\hline & .40 & & 1.35 & 0.60 & 0.50 & 10.92 & 0.92 & 1.06 & & 9.63 & 11.18 \\
\hline & & & 1.28 & & & 1.45 & & 1.75 & & 1.53 & 1.97 \\
\hline & .22 & .51 & 11.65 & 1.56 & 1.66 & 11.65 & 11.57 & 1.70 & 1.75 & 1.66 & 12.00 \\
\hline & & & 10.45 & & 0.44 & 10.61 & 10.61 & 0.70 & 00 & 1.08 & 11.21 \\
\hline & & & .64 & & & .67 & & .66 & & 1.71 & 12.00 \\
\hline & .60 & .72 & 12.09 & 1.84 & 2.03 & 11.83 & 11.72 & 1.66 & 1.70 & 11.62 & 11.91 \\
\hline Elazığ & .16 & & 11.84 & 11.36 & 11.45 & 11.62 & 11.69 & 11.61 & 1.70 & 11.53 & 11.87 \\
\hline & & & 11.84 & & 1.77 & 11.74 & 1.04 & 1.80 & & 1.86 & 12.18 \\
\hline & .06 & .17 & 10.54 & .18 & 0.62 & 10.76 & 10.79 & 0.92 & 1.01 & 1.01 & 11.21 \\
\hline Eskiş & 1.87 & .88 & 12.14 & 11.98 & 12.04 & 11.96 & 11.85 & 1.95 & 2.05 & 12.00 & 12.24 \\
\hline & & & 10.69 & & 0.74 & 10.95 & 1.00 & 1.08 & & 1.26 & 11.34 \\
\hline & & & 12.05 & 190 & 1.97 & 11.83 & 1100 & 1.39 & 11.75 & 11.54 & 12.02 \\
\hline $\begin{array}{l}\text { Gümüşhan } \\
\text { e }\end{array}$ & 10.55 & 10.81 & 11.13 & 10.22 & 10.22 & 9.55 & 8.90 & 7.57 & 7.67 & 8.77 & 8.64 \\
\hline & & & 10.06 & & & & & 10.04 & 10.42 & 10.62 & 10.67 \\
\hline & 10.79 & 11.17 & 11.45 & 11.05 & 11.34 & 11.49 & 11.46 & 11.45 & 11.57 & 11.54 & 11.78 \\
\hline Ĭğdır & 0.18 & 10.27 & 10.64 & 10.28 & 10.59 & 10.79 & 10.94 & 11.01 & 11.19 & 11.25 & 11.22 \\
\hline & 11.74 & 11.79 & 12.26 & 12.10 & 12.16 & 11.93 & 11.93 & 11.99 & 12.17 & 2.02 & 12.26 \\
\hline İstanbul & 11.04 & 11.05 & 11.26 & 11.16 & 11.41 & 11.46 & 11.44 & 11.49 & 11.53 & 11.62 & 11.88 \\
\hline
\end{tabular}


PJESS'2021 / 8(2)

\begin{tabular}{|c|c|c|c|c|c|c|c|c|c|c|c|}
\hline İzmir & 11.32 & 11.49 & 11.82 & 11.51 & 11.62 & 11.63 & 11.64 & 11.59 & 11.68 & 11.66 & 11.94 \\
\hline $\begin{array}{l}\text { Kahraman } \\
\text { maraş }\end{array}$ & 10.37 & 10.45 & 10.90 & 10.65 & 10.86 & 10.98 & 10.98 & 11.09 & 11.22 & 11.22 & 11.52 \\
\hline Karabük & 11.88 & 11.94 & 12.28 & 12.06 & 12.06 & 12.08 & 11.92 & 12.04 & 12.16 & 12.01 & 12.32 \\
\hline Karaman & 11.01 & 11.17 & 11.53 & 11.48 & 11.76 & 11.84 & 11.80 & 11.81 & 11.87 & 11.78 & 12.12 \\
\hline Kars & 9.63 & 9.86 & 10.24 & 10.07 & 10.37 & 10.66 & 10.71 & 10.71 & 10.86 & 10.88 & 11.07 \\
\hline Kastamonu & 11.06 & 11.23 & 11.78 & 11.49 & 11.69 & 11.83 & 11.66 & 11.79 & 11.88 & 11.78 & 12.07 \\
\hline Kayseri & 11.19 & 11.21 & 11.50 & 11.35 & 11.56 & 11.61 & 11.62 & 11.68 & 11.76 & 11.78 & 12.00 \\
\hline Kırıkkale & 11.42 & 11.66 & 12.04 & 11.67 & 11.69 & 11.84 & 11.85 & 12.09 & 11.99 & 11.74 & 12.08 \\
\hline Kurklareli & 11.79 & 11.79 & 12.03 & 11.96 & 11.98 & 11.85 & 11.78 & 11.78 & 11.75 & 11.72 & 11.96 \\
\hline Kurşehir & 11.47 & 11.56 & 11.95 & 11.79 & 11.75 & 11.73 & 11.72 & 11.77 & 11.87 & 11.67 & 12.00 \\
\hline Kilis & 10.63 & 10.73 & 11.10 & 10.99 & 11.19 & 11.31 & 11.39 & 11.17 & 11.28 & 11.17 & 11.57 \\
\hline Kocaeli & 11.58 & 11.56 & 11.86 & 11.70 & 11.80 & 11.80 & 11.80 & 11.95 & 11.97 & 12.08 & 12.26 \\
\hline Konya & 10.61 & 10.81 & 11.30 & 10.98 & 11.28 & 11.38 & 11.44 & 11.40 & 11.48 & 11.43 & 11.68 \\
\hline Kütahya & 11.44 & 11.74 & 12.18 & 11.96 & 12.09 & 12.06 & 11.92 & 11.98 & 12.11 & 11.95 & 12.19 \\
\hline Malatya & 11.26 & 11.38 & 11.78 & 11.52 & 11.72 & 11.75 & 11.70 & 11.82 & 11.95 & 11.95 & 12.11 \\
\hline Manisa & 11.00 & 11.20 & 11.53 & 11.45 & 11.60 & 11.65 & 11.62 & 11.59 & 11.66 & 11.64 & 11.91 \\
\hline Mardin & 9.60 & 9.74 & 10.11 & 9.87 & 10.26 & 10.55 & 10.60 & 11.47 & 10.83 & 10.90 & 10.95 \\
\hline Mersin & 11.07 & 11.26 & 11.76 & 11.36 & 11.46 & 11.56 & 11.54 & 11.60 & 11.68 & 11.68 & 11.95 \\
\hline Muğla & 11.30 & 11.32 & 11.60 & 11.56 & 11.70 & 11.58 & 11.57 & 11.64 & 11.69 & 11.64 & 11.92 \\
\hline Muş & 9.13 & 9.69 & 9.97 & 9.22 & 9.45 & 9.81 & 9.69 & 9.81 & 9.90 & 10.08 & 10.21 \\
\hline Nevşehir & 11.10 & 11.24 & 11.58 & 11.28 & 11.45 & 11.56 & 11.68 & 11.63 & 11.72 & 11.69 & 11.96 \\
\hline Niğde & 10.48 & 10.66 & 11.18 & 11.00 & 11.14 & 11.35 & 11.35 & 10.98 & 11.36 & 11.23 & 11.61 \\
\hline Ordu & 10.60 & 10.86 & 11.34 & 10.79 & 11.26 & 11.56 & 11.60 & 11.52 & 11.82 & 11.51 & 12.09 \\
\hline Osmaniye & 10.91 & 11.03 & 11.24 & 11.15 & 11.24 & 11.21 & 11.09 & 11.21 & 11.24 & 11.30 & 11.57 \\
\hline Rize & 11.94 & 11.97 & 12.35 & 12.14 & 12.36 & 12.34 & 12.33 & 12.22 & 12.31 & 12.04 & 12.45 \\
\hline Sakarya & 11.37 & 11.42 & 11.72 & 11.46 & 11.64 & 11.69 & 11.61 & 11.70 & 11.73 & 11.73 & 11.95 \\
\hline Samsun & 11.15 & 11.24 & 11.59 & 11.47 & 11.61 & 11.77 & 11.75 & 11.76 & 11.82 & 11.79 & 12.07 \\
\hline Siirt & 9.60 & 9.76 & 10.23 & 9.74 & 10.16 & 10.55 & 10.52 & 10.65 & 10.72 & 10.68 & 10.84 \\
\hline Sinop & 11.05 & 11.38 & 11.73 & 11.58 & 11.58 & 11.66 & 11.73 & 11.82 & 11.87 & 11.30 & 11.67 \\
\hline Sivas & 10.85 & 10.97 & 11.37 & 11.19 & 11.38 & 11.64 & 11.52 & 11.63 & 11.79 & 11.61 & 11.92 \\
\hline Şanlıurfa & 9.63 & 9.82 & 10.06 & 9.57 & 9.98 & 10.26 & 10.29 & 10.28 & 10.44 & 10.43 & 10.45 \\
\hline Şırnak & 9.32 & 9.47 & 9.88 & 9.50 & 10.07 & 10.36 & 10.20 & 10.18 & 10.60 & 10.63 & 10.65 \\
\hline Tekirdağ & 11.40 & 11.49 & 11.82 & 11.50 & 11.59 & 11.50 & 11.47 & 11.66 & 11.50 & 11.47 & 11.79 \\
\hline Tokat & 10.36 & 10.61 & 10.85 & 10.55 & 11.08 & 11.19 & 11.13 & 11.18 & 11.21 & 11.12 & 11.19 \\
\hline Trabzon & 11.48 & 11.54 & 12.00 & 11.82 & 12.04 & 12.16 & 12.06 & 12.04 & 12.05 & 11.87 & 12.27 \\
\hline Tunceli & 11.35 & 11.50 & 11.66 & 11.53 & 11.55 & 11.55 & 11.45 & 11.53 & 11.52 & 11.26 & 11.67 \\
\hline Uşak & 11.46 & 11.42 & 11.84 & 11.61 & 11.71 & 11.71 & 11.67 & 11.69 & 11.79 & 11.80 & 12.08 \\
\hline Van & 9.16 & 9.52 & 8.59 & 9.29 & 9.69 & 9.99 & 10.09 & 10.27 & 10.53 & 10.73 & 10.87 \\
\hline Yalova & 11.47 & 11.53 & 11.99 & 11.61 & 11.69 & 11.66 & 11.58 & 11.78 & 11.70 & 11.65 & 11.91 \\
\hline Yozgat & 10.00 & 10.20 & 10.80 & 10.60 & 10.84 & 10.73 & 10.86 & 10.88 & 11.01 & 10.90 & 11.28 \\
\hline Zonguldak & 11.24 & 11.38 & 11.73 & 11.69 & 11.80 & 11.85 & 11.85 & 11.81 & 11.85 & 11.79 & 12.08 \\
\hline
\end{tabular}


Tablo 10. İl ve Yıl Kırılımlı Eğitim, Gelir ve Sağlık Endeksleri (2013-2014) (EE-Education Index, GE-Income Index, SE-Health Index)

\begin{tabular}{|c|c|c|c|c|c|c|}
\hline & \multicolumn{3}{|c|}{2013} & \multicolumn{3}{|c|}{2014} \\
\hline & EE_lise & GE & SE & EE_lise & GE & SE \\
\hline Türkiye & 0.58 & 0.69 & 0.53 & 0.59 & 0.70 & 0.55 \\
\hline Adana & 0.65 & 0.49 & 0.38 & 0.66 & 0.50 & 0.44 \\
\hline Adiyaman & 0.52 & 0.24 & 0.81 & 0.54 & 0.29 & 0.82 \\
\hline Afyonkarahisar & 0.58 & 0.44 & 0.40 & 0.60 & 0.47 & 0.36 \\
\hline A ğr1 & 0.00 & 0.00 & 0.14 & 0.05 & 0.00 & 0.11 \\
\hline Aksaray & 0.49 & 0.41 & 0.64 & 0.48 & 0.47 & 0.58 \\
\hline Amasya & 0.77 & 0.50 & 0.52 & 0.76 & 0.49 & 0.51 \\
\hline Ankara & 0.92 & 0.90 & 0.74 & 0.91 & 0.89 & 0.80 \\
\hline Antalya & 0.74 & 0.77 & 0.76 & 0.73 & 0.76 & 0.76 \\
\hline Ardahan & 0.49 & 0.30 & 0.26 & 0.50 & 0.30 & 0.29 \\
\hline Artvin & 0.80 & 0.58 & 0.72 & 0.80 & 0.58 & 0.78 \\
\hline Aydın & 0.67 & 0.48 & 0.66 & 0.69 & 0.50 & 0.67 \\
\hline Balıkesir & 0.71 & 0.57 & 0.50 & 0.71 & 0.59 & 0.47 \\
\hline Bartın & 0.64 & 0.43 & 0.48 & 0.65 & 0.43 & 0.47 \\
\hline Batman & 0.34 & 0.21 & 0.69 & 0.37 & 0.20 & 0.67 \\
\hline Bayburt & 0.64 & 0.39 & 0.45 & 0.52 & 0.38 & 0.45 \\
\hline Bilecik & 0.85 & 0.83 & 0.47 & 0.81 & 0.82 & 0.49 \\
\hline Bingöl & 0.35 & 0.23 & 0.40 & 0.39 & 0.25 & 0.51 \\
\hline Bitlis & 0.24 & 0.21 & 0.41 & 0.27 & 0.21 & 0.45 \\
\hline Bolu & 0.80 & 0.77 & 0.72 & 0.77 & 0.78 & 0.76 \\
\hline Burdur & 0.69 & 0.60 & 0.66 & 0.63 & 0.62 & 0.65 \\
\hline Bursa & 0.76 & 0.76 & 0.43 & 0.77 & 0.77 & 0.45 \\
\hline Çanakkale & 0.75 & 0.68 & 0.48 & 0.72 & 0.70 & 0.49 \\
\hline Çankırı & 0.46 & 0.48 & 0.62 & 0.50 & 0.49 & 0.58 \\
\hline Çorum & 0.54 & 0.41 & 0.57 & 0.53 & 0.43 & 0.60 \\
\hline Denizli & 0.72 & 0.63 & 0.67 & 0.71 & 0.65 & 0.69 \\
\hline Diyarbakır & 0.29 & 0.24 & 0.53 & 0.30 & 0.25 & 0.58 \\
\hline Düzce & 0.67 & 0.61 & 0.55 & 0.69 & 0.64 & 0.49 \\
\hline Edirne & 0.78 & 0.60 & 0.53 & 0.73 & 0.62 & 0.49 \\
\hline Elazığ & 0.61 & 0.42 & 0.60 & 0.63 & 0.42 & 0.64 \\
\hline Erzincan & 0.69 & 0.62 & 0.74 & 0.67 & 0.61 & 0.75 \\
\hline Erzurum & 0.44 & 0.34 & 0.34 & 0.44 & 0.37 & 0.42 \\
\hline Eskişehir & 0.89 & 0.75 & 0.47 & 0.88 & 0.75 & 0.45 \\
\hline Gaziantep & 0.49 & 0.45 & 0.31 & 0.51 & 0.49 & 0.31 \\
\hline Giresun & 0.64 & 0.34 & 0.93 & 0.61 & 0.35 & 0.93 \\
\hline Gümüşhane & 0.39 & 0.47 & 0.98 & 0.25 & 0.47 & 0.89 \\
\hline Hakkâri & 0.23 & 0.18 & 0.38 & 0.22 & 0.19 & 0.42 \\
\hline Hatay & 0.59 & 0.40 & 0.55 & 0.60 & 0.41 & 0.53 \\
\hline Iğdır & 0.34 & 0.30 & 0.55 & 0.36 & 0.29 & 0.60 \\
\hline
\end{tabular}




\begin{tabular}{|c|c|c|c|c|c|c|}
\hline Isparta & 0.82 & 0.54 & 0.64 & 0.78 & 0.55 & 0.67 \\
\hline İstanbul & 0.75 & 1.00 & 0.67 & 0.77 & 1.00 & 0.67 \\
\hline İzmir & 0.80 & 0.79 & 0.71 & 0.79 & 0.79 & 0.69 \\
\hline Kahramanmaraş & 0.48 & 0.37 & 0.71 & 0.49 & 0.38 & 0.75 \\
\hline Karabük & 0.77 & 0.54 & 0.60 & 0.76 & 0.56 & 0.64 \\
\hline Karaman & 0.71 & 0.64 & 0.74 & 0.71 & 0.65 & 0.73 \\
\hline Kars & 0.34 & 0.21 & 0.48 & 0.38 & 0.23 & 0.49 \\
\hline Kastamonu & 0.58 & 0.51 & 0.53 & 0.59 & 0.52 & 0.45 \\
\hline Kayseri & 0.73 & 0.61 & 0.55 & 0.72 & 0.61 & 0.55 \\
\hline Kırıkkale & 0.78 & 0.31 & 0.00 & 0.79 & 0.29 & 0.00 \\
\hline Kırklareli & 0.83 & 0.52 & 0.48 & 0.79 & 0.51 & 0.38 \\
\hline Kırşehir & 0.72 & 0.72 & 0.36 & 0.71 & 0.73 & 0.38 \\
\hline Kilis & 0.55 & 0.45 & 0.62 & 0.56 & 0.45 & 0.58 \\
\hline Kocaeli & 0.83 & 1.00 & 0.48 & 0.83 & 1.00 & 0.53 \\
\hline Konya & 0.62 & 0.52 & 0.57 & 0.62 & 0.55 & 0.56 \\
\hline Kütahya & 0.75 & 0.50 & 0.33 & 0.73 & 0.52 & 0.35 \\
\hline Malatya & 0.71 & 0.35 & 0.66 & 0.71 & 0.36 & 0.69 \\
\hline Manisa & 0.65 & 0.62 & 0.48 & 0.65 & 0.64 & 0.44 \\
\hline Mardin & 0.23 & 0.25 & 1.00 & 0.26 & 0.27 & 0.96 \\
\hline Mersin & 0.68 & 0.54 & 0.59 & 0.69 & 0.56 & 0.60 \\
\hline Muğla & 0.74 & 0.70 & 0.97 & 0.73 & 0.71 & 1.00 \\
\hline Muş & 0.06 & 0.21 & 0.45 & 0.09 & 0.20 & 0.45 \\
\hline Nevşehir & 0.66 & 0.47 & 0.41 & 0.66 & 0.49 & 0.47 \\
\hline Niğde & 0.58 & 0.41 & 0.59 & 0.60 & 0.44 & 0.62 \\
\hline Ordu & 0.51 & 0.30 & 0.86 & 0.55 & 0.33 & 0.87 \\
\hline Osmaniye & 0.63 & 0.36 & 0.60 & 0.62 & 0.38 & 0.65 \\
\hline Rize & 0.81 & 0.57 & 0.86 & 0.80 & 0.59 & 0.84 \\
\hline Sakarya & 0.72 & 0.63 & 0.43 & 0.72 & 0.64 & 0.45 \\
\hline Samsun & 0.64 & 0.48 & 0.59 & 0.66 & 0.50 & 0.56 \\
\hline Siirt & 0.24 & 0.08 & 0.38 & 0.30 & 0.09 & 0.44 \\
\hline Sinop & 0.58 & 0.22 & 0.57 & 0.58 & 0.22 & 0.53 \\
\hline Sivas & 0.61 & 0.45 & 0.67 & 0.63 & 0.43 & 0.65 \\
\hline Şanlıurfa & 0.11 & 0.23 & 0.59 & 0.14 & 0.22 & 0.55 \\
\hline Şırnak & 0.15 & 0.48 & 0.45 & 0.18 & 0.48 & 0.51 \\
\hline Tekirdağ & 0.77 & 0.83 & 0.43 & 0.75 & 0.83 & 0.38 \\
\hline Tokat & 0.51 & 0.31 & 0.45 & 0.51 & 0.31 & 0.47 \\
\hline Trabzon & 0.77 & 0.56 & 0.93 & 0.78 & 0.58 & 0.87 \\
\hline Tunceli & 0.68 & 0.58 & 1.00 & 0.68 & 0.59 & 1.00 \\
\hline Uşak & 0.71 & 0.57 & 0.52 & 0.69 & 0.58 & 0.55 \\
\hline Van & 0.12 & 0.11 & 0.07 & 0.15 & 0.09 & 0.11 \\
\hline Yalova & 0.77 & 0.70 & 0.78 & 0.78 & 0.74 & 0.65 \\
\hline Yozgat & 0.46 & 0.36 & 0.52 & 0.42 & 0.38 & 0.51 \\
\hline Zonguldak & 0.70 & 0.46 & 0.53 & 0.70 & 0.47 & 0.53 \\
\hline
\end{tabular}


Tablo 11. İl ve Yıl Kırılımlı Eğitim, Gelir ve Sağlık Endeksleri (2015-2016) (EE-Education Index,

\section{GE-Income Index, SE-Health Index)}

\begin{tabular}{|c|c|c|c|c|c|c|}
\hline & \multicolumn{3}{|c|}{2015} & \multicolumn{3}{|c|}{2016} \\
\hline & EE_lise & GE & SE & EE_lise & GE & SE \\
\hline Türkiye & 0.62 & 0.69 & 0.55 & 0.68 & 0.68 & 0.55 \\
\hline Adana & 0.68 & 0.49 & 0.44 & 0.75 & 0.49 & 0.44 \\
\hline Adiyaman & 0.58 & 0.27 & 0.82 & 0.65 & 0.24 & 0.82 \\
\hline Afyonkarahisar & 0.62 & 0.46 & 0.36 & 0.67 & 0.45 & 0.36 \\
\hline Ağrn & 0.13 & 0.00 & 0.11 & 0.25 & 0.00 & 0.11 \\
\hline Aksaray & 0.53 & 0.48 & 0.58 & 0.64 & 0.45 & 0.58 \\
\hline Amasya & 0.76 & 0.51 & 0.51 & 0.79 & 0.49 & 0.51 \\
\hline Ankara & 0.91 & 0.88 & 0.80 & 0.95 & 0.88 & 0.80 \\
\hline Antalya & 0.76 & 0.75 & 0.76 & 0.82 & 0.68 & 0.76 \\
\hline Ardahan & 0.55 & 0.37 & 0.29 & 0.61 & 0.36 & 0.29 \\
\hline Artvin & 0.80 & 0.58 & 0.78 & 0.84 & 0.57 & 0.78 \\
\hline Aydin & 0.70 & 0.48 & 0.67 & 0.75 & 0.47 & 0.67 \\
\hline Balıkesir & 0.73 & 0.56 & 0.47 & 0.77 & 0.57 & 0.47 \\
\hline Bartın & 0.68 & 0.42 & 0.47 & 0.69 & 0.40 & 0.47 \\
\hline Batman & 0.45 & 0.16 & 0.67 & 0.54 & 0.14 & 0.67 \\
\hline Bayburt & 0.56 & 0.38 & 0.45 & 0.51 & 0.35 & 0.45 \\
\hline Bilecik & 0.80 & 0.79 & 0.49 & 0.86 & 0.77 & 0.49 \\
\hline Bingöl & 0.47 & 0.26 & 0.51 & 0.54 & 0.26 & 0.51 \\
\hline Bitlis & 0.34 & 0.19 & 0.45 & 0.45 & 0.15 & 0.45 \\
\hline Bolu & 0.76 & 0.76 & 0.76 & 0.81 & 0.73 & 0.76 \\
\hline Burdur & 0.67 & 0.61 & 0.65 & 0.73 & 0.59 & 0.65 \\
\hline Bursa & 0.79 & 0.76 & 0.45 & 0.83 & 0.75 & 0.45 \\
\hline Çanakkale & 0.73 & 0.68 & 0.49 & 0.76 & 0.68 & 0.49 \\
\hline Çankırı & 0.55 & 0.50 & 0.58 & 0.63 & 0.50 & 0.58 \\
\hline Çorum & 0.55 & 0.43 & 0.60 & 0.65 & 0.42 & 0.60 \\
\hline Denizli & 0.72 & 0.62 & 0.69 & 0.78 & 0.63 & 0.69 \\
\hline Diyarbakır & 0.36 & 0.24 & 0.58 & 0.46 & 0.22 & 0.58 \\
\hline Düzce & 0.71 & 0.65 & 0.49 & 0.76 & 0.62 & 0.49 \\
\hline Edirne & 0.73 & 0.59 & 0.49 & 0.76 & 0.57 & 0.49 \\
\hline Elazığ & 0.67 & 0.42 & 0.64 & 0.70 & 0.40 & 0.64 \\
\hline Erzincan & 0.69 & 0.57 & 0.75 & 0.74 & 0.56 & 0.75 \\
\hline Erzurum & 0.51 & 0.36 & 0.42 & 0.60 & 0.36 & 0.42 \\
\hline Eskişehir & 0.87 & 0.73 & 0.45 & 0.91 & 0.72 & 0.45 \\
\hline Gaziantep & 0.56 & 0.49 & 0.31 & 0.64 & 0.48 & 0.31 \\
\hline Giresun & 0.64 & 0.42 & 0.93 & 0.63 & 0.33 & 0.93 \\
\hline Gümüşhane & 0.25 & 0.43 & 0.89 & 0.22 & 0.35 & 0.89 \\
\hline Hakkâri & 0.32 & 0.17 & 0.42 & 0.42 & 0.19 & 0.42 \\
\hline Hatay & 0.63 & 0.41 & 0.53 & 0.68 & 0.41 & 0.53 \\
\hline Iğdır & 0.44 & 0.32 & 0.60 & 0.52 & 0.28 & 0.60 \\
\hline
\end{tabular}




\begin{tabular}{|c|c|c|c|c|c|c|}
\hline Isparta & 0.80 & 0.52 & 0.67 & 0.84 & 0.54 & 0.67 \\
\hline İstanbul & 0.80 & 1.00 & 0.67 & 0.85 & 1.00 & 0.67 \\
\hline İzmir & 0.82 & 0.77 & 0.69 & 0.85 & 0.77 & 0.69 \\
\hline Kahramanmaraş & 0.54 & 0.38 & 0.75 & 0.63 & 0.35 & 0.75 \\
\hline Karabük & 0.75 & 0.54 & 0.64 & 0.79 & 0.52 & 0.64 \\
\hline Karaman & 0.72 & 0.64 & 0.73 & 0.76 & 0.61 & 0.73 \\
\hline Kars & 0.44 & 0.28 & 0.49 & 0.53 & 0.26 & 0.49 \\
\hline Kastamonu & 0.58 & 0.50 & 0.45 & 0.63 & 0.49 & 0.45 \\
\hline Kayseri & 0.75 & 0.59 & 0.55 & 0.80 & 0.58 & 0.55 \\
\hline Kırıkkale & 0.80 & 0.36 & 0.00 & 0.86 & 0.32 & 0.00 \\
\hline Kırklareli & 0.80 & 0.51 & 0.38 & 0.83 & 0.49 & 0.38 \\
\hline Kırşehir & 0.72 & 0.70 & 0.38 & 0.77 & 0.69 & 0.38 \\
\hline Kilis & 0.61 & 0.44 & 0.58 & 0.65 & 0.45 & 0.58 \\
\hline Kocaeli & 0.85 & 0.99 & 0.53 & 0.91 & 0.98 & 0.53 \\
\hline Konya & 0.66 & 0.55 & 0.56 & 0.70 & 0.53 & 0.56 \\
\hline Kütahya & 0.72 & 0.50 & 0.35 & 0.75 & 0.49 & 0.35 \\
\hline Malatya & 0.72 & 0.38 & 0.69 & 0.78 & 0.36 & 0.69 \\
\hline Manisa & 0.67 & 0.63 & 0.44 & 0.70 & 0.63 & 0.44 \\
\hline Mardin & 0.34 & 0.28 & 0.96 & 0.51 & 0.25 & 0.96 \\
\hline Mersin & 0.71 & 0.56 & 0.60 & 0.76 & 0.55 & 0.60 \\
\hline Muğla & 0.75 & 0.69 & 1.00 & 0.81 & 0.66 & 1.00 \\
\hline Muş & 0.16 & 0.18 & 0.45 & 0.30 & 0.15 & 0.45 \\
\hline Nevşehir & 0.71 & 0.50 & 0.47 & 0.74 & 0.45 & 0.47 \\
\hline Niğde & 0.63 & 0.46 & 0.62 & 0.65 & 0.42 & 0.62 \\
\hline Ordu & 0.59 & 0.42 & 0.87 & 0.62 & 0.32 & 0.87 \\
\hline Osmaniye & 0.64 & 0.36 & 0.65 & 0.73 & 0.36 & 0.65 \\
\hline Rize & 0.81 & 0.58 & 0.84 & 0.83 & 0.57 & 0.84 \\
\hline Sakarya & 0.73 & 0.65 & 0.45 & 0.78 & 0.63 & 0.45 \\
\hline Samsun & 0.68 & 0.50 & 0.56 & 0.72 & 0.48 & 0.56 \\
\hline Siirt & 0.34 & 0.09 & 0.44 & 0.44 & 0.06 & 0.44 \\
\hline Sinop & 0.61 & 0.18 & 0.53 & 0.66 & 0.16 & 0.53 \\
\hline Sivas & 0.64 & 0.41 & 0.65 & 0.70 & 0.40 & 0.65 \\
\hline Şanlıurfa & 0.22 & 0.22 & 0.55 & 0.31 & 0.22 & 0.55 \\
\hline Şırnak & 0.22 & 0.47 & 0.51 & 0.31 & 0.46 & 0.51 \\
\hline Tekirdağ & 0.77 & 0.81 & 0.38 & 0.84 & 0.80 & 0.38 \\
\hline Tokat & 0.54 & 0.33 & 0.47 & 0.61 & 0.30 & 0.47 \\
\hline Trabzon & 0.79 & 0.58 & 0.87 & 0.81 & 0.56 & 0.87 \\
\hline Tunceli & 0.70 & 0.57 & 1.00 & 0.76 & 0.59 & 1.00 \\
\hline Uşak & 0.70 & 0.55 & 0.55 & 0.74 & 0.54 & 0.55 \\
\hline Van & 0.25 & 0.05 & 0.11 & 0.37 & 0.07 & 0.11 \\
\hline Yalova & 0.77 & 0.74 & 0.65 & 0.82 & 0.73 & 0.65 \\
\hline Yozgat & 0.49 & 0.39 & 0.51 & 0.56 & 0.38 & 0.51 \\
\hline Zonguldak & 0.72 & 0.46 & 0.53 & 0.74 & 0.46 & 0.53 \\
\hline
\end{tabular}


Tablo 12. İl ve Yıl Kırılımlı Eğitim, Gelir ve Sağlık Endeksleri (2017-2018) (EE-Education Index, GE-Income Index, SE-Health Index)

\begin{tabular}{|l|c|c|c|c|c|c|}
\hline & \multicolumn{3}{|c|}{2017} & \multicolumn{3}{|c|}{2018} \\
\hline & EE_lise & GE & SE & EE_lise & GE & SE \\
\hline Türkiye & 0.68 & 0.68 & 0.41 & 0.68 & 0.67 & 0.41 \\
\hline Adana & 0.75 & 0.49 & 0.30 & 0.75 & 0.46 & 0.30 \\
\hline Adıyaman & 0.65 & 0.23 & 0.78 & 0.65 & 0.24 & 0.78 \\
\hline Afyonkarahisar & 0.67 & 0.43 & 0.22 & 0.65 & 0.45 & 0.22 \\
\hline Ağrı & 0.27 & 0.00 & 0.15 & 0.23 & 0.00 & 0.15 \\
\hline Aksaray & 0.62 & 0.45 & 0.48 & 0.60 & 0.44 & 0.48 \\
\hline Amasya & 0.78 & 0.47 & 0.52 & 0.79 & 0.45 & 0.52 \\
\hline Ankara & 0.94 & 0.86 & 0.72 & 0.97 & 0.83 & 0.72 \\
\hline Antalya & 0.82 & 0.68 & 0.70 & 0.81 & 0.69 & 0.70 \\
\hline Ardahan & 0.61 & 0.36 & 0.17 & 0.62 & 0.34 & 0.17 \\
\hline Artvin & 0.83 & 0.58 & 0.70 & 0.83 & 0.58 & 0.70 \\
\hline Aydın & 0.74 & 0.48 & 0.52 & 0.75 & 0.46 & 0.52 \\
\hline Balıkesir & 0.77 & 0.57 & 0.30 & 0.78 & 0.55 & 0.30 \\
\hline Bartın & 0.69 & 0.39 & 0.39 & 0.69 & 0.38 & 0.39 \\
\hline Batman & 0.56 & 0.17 & 0.70 & 0.56 & 0.19 & 0.70 \\
\hline Bayburt & 0.67 & 0.31 & 0.65 & 0.63 & 0.36 & 0.65 \\
\hline Bilecik & 0.84 & 0.74 & 0.37 & 0.83 & 0.72 & 0.37 \\
\hline Bingöl & 0.57 & 0.25 & 0.59 & 0.57 & 0.24 & 0.59 \\
\hline Bitlis & 0.45 & 0.12 & 0.50 & 0.45 & 0.10 & 0.50 \\
\hline Bolu & 0.80 & 0.70 & 0.67 & 0.82 & 0.68 & 0.67 \\
\hline Burdur & 0.73 & 0.56 & 0.67 & 0.73 & 0.52 & 0.67 \\
\hline Bursa & 0.83 & 0.76 & 0.35 & 0.83 & 0.75 & 0.35 \\
\hline Çanakkale & 0.77 & 0.68 & 0.41 & 0.77 & 0.67 & 0.41 \\
\hline Çankır1 & 0.62 & 0.46 & 0.41 & 0.39 & 0.40 & 0.41 \\
\hline Çorum & 0.63 & 0.41 & 0.54 & 0.61 & 0.39 & 0.54 \\
\hline Denizli & 0.78 & 0.63 & 0.46 & 0.78 & 0.63 & 0.46 \\
\hline Diyarbakır & 0.48 & 0.21 & 0.61 & 0.49 & 0.18 & 0.61 \\
\hline Düzce & 0.76 & 0.60 & 0.30 & 0.77 & 0.56 & 0.30 \\
\hline Edirne & 0.76 & 0.57 & 0.28 & 0.76 & 0.54 & 0.28 \\
\hline Elazı̆g & 0.71 & 0.39 & 0.54 & 0.69 & 0.37 & 0.54 \\
\hline Erzincan & 0.74 & 0.56 & 0.67 & 0.75 & 0.56 & 0.67 \\
\hline Erzurum & 0.60 & 0.36 & 0.26 & 0.58 & 0.35 & 0.26 \\
\hline Eskişehir & 0.91 & 0.71 & 0.41 & 0.93 & 0.70 & 0.41 \\
\hline Gaziantep & 0.65 & 0.48 & 0.17 & 0.64 & 0.49 & 0.17 \\
\hline Giresun & 0.65 & 0.34 & 0.78 & 0.63 & 0.30 & 0.78 \\
\hline Gümüşhane & 0.32 & 0.80 & 0.26 & 0.34 & 0.80 \\
\hline Hakkâri & & & & 0.50 & 0.24 & 0.22 \\
\hline
\end{tabular}




\begin{tabular}{|c|c|c|c|c|c|c|}
\hline Hatay & 0.69 & 0.43 & 0.39 & 0.68 & 0.43 & 0.39 \\
\hline Iğdır & 0.53 & 0.34 & 0.59 & 0.53 & 0.33 & 0.59 \\
\hline Isparta & 0.85 & 0.52 & 0.57 & 0.85 & 0.51 & 0.57 \\
\hline İstanbul & 0.84 & 1.00 & 0.57 & 0.85 & 0.98 & 0.57 \\
\hline İzmir & 0.86 & 0.77 & 0.54 & 0.87 & 0.77 & 0.54 \\
\hline Kahramanmaraş & 0.64 & 0.36 & 0.67 & 0.63 & 0.35 & 0.67 \\
\hline Karabük & 0.80 & 0.54 & 0.50 & 0.80 & 0.55 & 0.50 \\
\hline Karaman & 0.75 & 0.62 & 0.57 & 0.76 & 0.59 & 0.57 \\
\hline Kars & 0.54 & 0.26 & 0.26 & 0.51 & 0.25 & 0.26 \\
\hline Kastamonu & 0.64 & 0.49 & 0.28 & 0.63 & 0.47 & 0.28 \\
\hline Kayseri & 0.80 & 0.58 & 0.39 & 0.82 & 0.55 & 0.39 \\
\hline Kırıkkale & 0.84 & 0.33 & 0.00 & 0.82 & 0.30 & 0.00 \\
\hline Kırklareli & 0.83 & 0.55 & 0.37 & 0.83 & 0.54 & 0.37 \\
\hline Kırşehir & 0.76 & 0.68 & 0.35 & 0.73 & 0.68 & 0.35 \\
\hline Kilis & 0.65 & 0.45 & 0.52 & 0.64 & 0.43 & 0.52 \\
\hline Kocaeli & 0.90 & 1.00 & 0.43 & 0.95 & 1.00 & 0.43 \\
\hline Konya & 0.71 & 0.53 & 0.48 & 0.70 & 0.52 & 0.48 \\
\hline Kütahya & 0.76 & 0.50 & 0.15 & 0.76 & 0.49 & 0.15 \\
\hline Malatya & 0.78 & 0.35 & 0.63 & 0.80 & 0.31 & 0.63 \\
\hline Manisa & 0.70 & 0.63 & 0.22 & 0.71 & 0.65 & 0.22 \\
\hline Mardin & 0.44 & 0.26 & 0.80 & 0.42 & 0.26 & 0.80 \\
\hline Mersin & 0.76 & 0.55 & 0.46 & 0.77 & 0.54 & 0.46 \\
\hline Muğla & 0.81 & 0.66 & 0.91 & 0.82 & 0.65 & 0.91 \\
\hline Muş & 0.30 & 0.16 & 0.30 & 0.26 & 0.15 & 0.30 \\
\hline Nevşehir & 0.74 & 0.43 & 0.37 & 0.73 & 0.42 & 0.37 \\
\hline Niğde & 0.68 & 0.41 & 0.33 & 0.65 & 0.41 & 0.33 \\
\hline Ordu & 0.65 & 0.34 & 0.70 & 0.61 & 0.33 & 0.70 \\
\hline Osmaniye & 0.73 & 0.38 & 0.41 & 0.73 & 0.40 & 0.41 \\
\hline Rize & 0.83 & 0.58 & 0.63 & 0.83 & 0.56 & 0.63 \\
\hline Sakarya & 0.78 & 0.64 & 0.30 & 0.80 & 0.64 & 0.30 \\
\hline Samsun & 0.72 & 0.47 & 0.43 & 0.73 & 0.43 & 0.43 \\
\hline Siirt & 0.45 & 0.06 & 0.35 & 0.42 & 0.04 & 0.35 \\
\hline Sinop & 0.66 & 0.16 & 0.50 & 0.58 & 0.17 & 0.50 \\
\hline Sivas & 0.71 & 0.38 & 0.50 & 0.69 & 0.33 & 0.50 \\
\hline Şanlıurfa & 0.32 & 0.24 & 0.33 & 0.26 & 0.24 & 0.33 \\
\hline Şırnak & 0.38 & 0.46 & 0.41 & 0.36 & 0.43 & 0.41 \\
\hline Tekirdağ & 0.82 & 0.81 & 0.33 & 0.82 & 0.80 & 0.33 \\
\hline Tokat & 0.60 & 0.28 & 0.30 & 0.58 & 0.26 & 0.30 \\
\hline Trabzon & 0.81 & 0.56 & 0.85 & 0.80 & 0.53 & 0.85 \\
\hline Tunceli & 0.75 & 0.60 & 1.00 & 0.72 & 0.56 & 1.00 \\
\hline Uşak & 0.73 & 0.56 & 0.43 & 0.75 & 0.55 & 0.43 \\
\hline Van & 0.40 & 0.06 & 0.20 & 0.39 & 0.04 & 0.20 \\
\hline Yalova & 0.80 & 0.74 & 0.54 & 0.78 & 0.74 & 0.54 \\
\hline
\end{tabular}




\begin{tabular}{|l|l|l|l|l|l|l|} 
Yozgat & 0.57 & 0.36 & 0.30 & 0.52 & 0.33 & 0.30 \\
\hline Zonguldak & 0.73 & 0.47 & 0.37 & 0.74 & 0.49 & 0.37 \\
\hline
\end{tabular}

Tablo 13. İl ve Y1l Kırılımlı İnsani Gelişme Endeksi (HDI)

\begin{tabular}{|l|c|c|c|c|c|c|}
\hline & 2013 & 2014 & 2015 & 2016 & 2017 & 2018 \\
\hline & İGE_lise & İGE_lise & İGE_lise & İGE_lise & İGE_lise & İGE_lise \\
\hline Türkiye & 0.60 & 0.61 & 0.62 & 0.63 & 0.58 & 0.57 \\
\hline Adana & 0.49 & 0.53 & 0.53 & 0.54 & 0.48 & 0.47 \\
\hline Adıyaman & 0.47 & 0.50 & 0.50 & 0.50 & 0.49 & 0.50 \\
\hline Afyonkarahisar & 0.47 & 0.47 & 0.47 & 0.48 & 0.40 & 0.40 \\
\hline Ağrı & $\mathbf{0 . 0 1}$ & $\mathbf{0 . 0 2}$ & $\mathbf{0 . 0 2}$ & $\mathbf{0 . 0 3}$ & $\mathbf{0 . 0 3}$ & $\mathbf{0 . 0 3}$ \\
\hline Aksaray & 0.51 & 0.51 & 0.53 & 0.55 & 0.51 & 0.50 \\
\hline Amasya & 0.58 & 0.58 & 0.58 & 0.58 & 0.58 & 0.57 \\
\hline Ankara & $\mathbf{0 . 8 5}$ & $\mathbf{0 . 8 7}$ & $\mathbf{0 . 8 6}$ & $\mathbf{0 . 8 8}$ & $\mathbf{0 . 8 3}$ & $\mathbf{0 . 8 3}$ \\
\hline Antalya & $\mathbf{0 . 7 6}$ & $\mathbf{0 . 7 5}$ & $\mathbf{0 . 7 6}$ & 0.75 & $\mathbf{0 . 7 3}$ & $\mathbf{0 . 7 3}$ \\
\hline Ardahan & 0.34 & 0.35 & 0.39 & 0.40 & 0.34 & 0.33 \\
\hline Artvin & 0.69 & 0.71 & 0.71 & 0.72 & 0.69 & 0.70 \\
\hline Aydın & 0.60 & 0.61 & 0.61 & 0.62 & 0.57 & 0.56 \\
\hline Balıkesir & 0.59 & 0.58 & 0.58 & 0.59 & 0.51 & 0.51 \\
\hline Bartın & 0.51 & 0.51 & 0.51 & 0.51 & 0.47 & 0.47 \\
\hline Batman & 0.37 & 0.37 & 0.36 & 0.37 & 0.41 & 0.42 \\
\hline Bayburt & 0.48 & 0.45 & 0.46 & 0.43 & 0.52 & 0.53 \\
\hline Bilecik & 0.69 & 0.69 & 0.68 & 0.69 & 0.61 & 0.61 \\
\hline Bingöl & 0.32 & 0.37 & 0.39 & 0.41 & 0.44 & 0.43 \\
\hline Bitlis & 0.28 & 0.30 & 0.31 & 0.31 & 0.30 & 0.28 \\
\hline Bolu & $\mathbf{0 . 7 7}$ & $\mathbf{0 . 7 7}$ & $\mathbf{0 . 7 6}$ & $\mathbf{0 . 7 7}$ & 0.72 & 0.72 \\
\hline Burdur & 0.65 & 0.63 & 0.64 & 0.65 & 0.65 & 0.64 \\
\hline Bursa & 0.63 & 0.65 & 0.65 & 0.66 & 0.60 & 0.60 \\
\hline Çanakkale & 0.63 & 0.63 & 0.62 & 0.63 & 0.60 & 0.60 \\
\hline Çankırı & 0.51 & 0.52 & 0.54 & 0.57 & 0.49 & 0.40 \\
\hline Çorum & 0.50 & 0.52 & 0.52 & 0.54 & 0.52 & 0.51 \\
\hline Denizli & 0.67 & 0.68 & 0.68 & 0.70 & 0.61 & 0.61 \\
\hline Diyarbakır & 0.33 & 0.35 & 0.37 & 0.39 & 0.39 & 0.38 \\
\hline Düzce & 0.61 & 0.60 & 0.61 & 0.61 & 0.52 & 0.51 \\
\hline Edirne & 0.63 & 0.61 & 0.60 & 0.60 & 0.50 & 0.49 \\
\hline Elazı̆g & 0.54 & 0.55 & 0.56 & 0.56 & 0.53 & 0.52 \\
\hline Erzincan & 0.68 & 0.67 & 0.66 & 0.68 & 0.66 & 0.66 \\
\hline Erzurum & 0.37 & 0.41 & 0.43 & 0.45 & 0.39 & 0.38 \\
\hline Eskişehir & 0.68 & 0.67 & 0.66 & 0.67 & 0.64 & 0.64 \\
\hline Gaziantep & 0.41 & 0.42 & 0.44 & 0.45 & 0.38 & 0.38 \\
\hline Giresun & 0.59 & 0.58 & 0.63 & 0.58 & 0.56 & 0.53 \\
\hline Gümüşhane & 0.56 & 0.47 & 0.45 & 0.41 & 0.36 & 0.41 \\
\hline & & & & & & \\
\hline
\end{tabular}




\begin{tabular}{|c|c|c|c|c|c|c|}
\hline Hakkâri & 0.25 & 0.26 & 0.29 & 0.32 & 0.28 & 0.30 \\
\hline Hatay & 0.51 & 0.51 & 0.52 & 0.53 & 0.49 & 0.49 \\
\hline Iğdır & 0.38 & 0.40 & 0.44 & 0.44 & 0.47 & 0.47 \\
\hline Isparta & 0.65 & 0.66 & 0.65 & 0.67 & 0.63 & 0.62 \\
\hline İstanbul & 0.80 & 0.80 & 0.81 & 0.83 & 0.78 & 0.78 \\
\hline İzmir & 0.76 & 0.76 & 0.76 & 0.77 & 0.71 & 0.71 \\
\hline Kahramanmaraş & 0.50 & 0.52 & 0.53 & 0.55 & 0.54 & 0.53 \\
\hline Karabük & 0.63 & 0.64 & 0.63 & 0.64 & 0.60 & 0.60 \\
\hline Karaman & 0.70 & 0.69 & 0.70 & 0.70 & 0.64 & 0.63 \\
\hline Kars & 0.32 & 0.35 & 0.39 & 0.41 & 0.33 & 0.32 \\
\hline Kastamonu & 0.54 & 0.52 & 0.51 & 0.52 & 0.44 & 0.44 \\
\hline Kayseri & 0.63 & 0.62 & 0.62 & 0.63 & 0.57 & 0.56 \\
\hline Kirıkkale & 0.06 & 0.06 & 0.07 & 0.07 & 0.06 & 0.06 \\
\hline Kurklareli & 0.59 & 0.54 & 0.54 & 0.54 & 0.55 & 0.55 \\
\hline Kırşehir & 0.57 & 0.58 & 0.58 & 0.59 & 0.56 & 0.56 \\
\hline Kilis & 0.53 & 0.53 & 0.54 & 0.55 & 0.54 & 0.52 \\
\hline Kocaeli & 0.74 & 0.76 & 0.76 & 0.78 & 0.73 & 0.74 \\
\hline Konya & 0.57 & 0.58 & 0.59 & 0.60 & 0.56 & 0.56 \\
\hline Kütahya & 0.50 & 0.51 & 0.50 & 0.50 & 0.39 & 0.38 \\
\hline Malatya & 0.55 & 0.56 & 0.57 & 0.58 & 0.55 & 0.54 \\
\hline Manisa & 0.58 & 0.57 & 0.57 & 0.58 & 0.46 & 0.47 \\
\hline Mardin & 0.39 & 0.41 & 0.45 & 0.50 & 0.45 & 0.44 \\
\hline Mersin & 0.60 & 0.61 & 0.62 & 0.63 & 0.58 & 0.57 \\
\hline Muğla & 0.79 & 0.80 & 0.80 & 0.81 & 0.79 & 0.79 \\
\hline Muş & 0.18 & 0.20 & 0.24 & 0.28 & 0.24 & 0.23 \\
\hline Nevşehir & 0.51 & 0.54 & 0.55 & 0.54 & 0.49 & 0.49 \\
\hline Niğde & 0.52 & 0.55 & 0.57 & 0.55 & 0.45 & 0.44 \\
\hline Ordu & 0.51 & 0.54 & 0.60 & 0.56 & 0.54 & 0.52 \\
\hline Osmaniye & 0.51 & 0.54 & 0.53 & 0.56 & 0.48 & 0.50 \\
\hline Rize & 0.73 & 0.74 & 0.73 & 0.73 & 0.67 & 0.67 \\
\hline Sakarya & 0.58 & 0.60 & 0.60 & 0.61 & 0.53 & 0.54 \\
\hline Samsun & 0.57 & 0.57 & 0.58 & 0.58 & 0.53 & 0.52 \\
\hline Siirt & 0.19 & 0.22 & 0.24 & 0.22 & 0.21 & 0.18 \\
\hline Sinop & 0.42 & 0.41 & 0.39 & 0.38 & 0.37 & 0.36 \\
\hline Sivas & 0.57 & 0.56 & 0.56 & 0.57 & 0.51 & 0.48 \\
\hline Şanlıurfa & 0.24 & 0.26 & 0.30 & 0.33 & 0.29 & 0.28 \\
\hline Şırnak & 0.32 & 0.35 & 0.38 & 0.42 & 0.41 & 0.40 \\
\hline Tekirdağ & 0.65 & 0.62 & 0.62 & 0.64 & 0.60 & 0.60 \\
\hline Tokat & 0.41 & 0.42 & 0.44 & 0.44 & 0.37 & 0.36 \\
\hline Trabzon & 0.74 & 0.74 & 0.73 & 0.74 & 0.73 & 0.71 \\
\hline Tunceli & 0.73 & 0.74 & 0.74 & 0.77 & 0.77 & 0.74 \\
\hline Uşak & 0.59 & 0.60 & 0.59 & 0.60 & 0.56 & 0.56 \\
\hline Van & 0.09 & 0.12 & 0.11 & 0.14 & 0.16 & 0.14 \\
\hline
\end{tabular}




\begin{tabular}{|l|l|l|l|l|l|l|}
\hline Yalova & 0.75 & 0.72 & 0.72 & 0.73 & 0.68 & 0.68 \\
\hline Yozgat & 0.44 & 0.43 & 0.46 & 0.48 & 0.39 & 0.38 \\
\hline Zonguldak & 0.56 & 0.56 & 0.56 & 0.56 & 0.50 & 0.51 \\
\hline
\end{tabular}

